\title{
Global Perspectives on Observing Ocean Boundary Current Systems
}

\section{OPEN ACCESS}

Edited by:

Sabrina Speich,

École Normale Supérieure, France

Reviewed by:

Moacyr Cunha de Araujo Filho, Federal Rural University

of Pernambuco, Brazil

Eitarou Oka

The University of Tokyo, Japan

*Correspondence:

Robert E. Todd

rtodd@whoi.edu

Specialty section

This article was submitted to

Ocean Observation,

a section of the journal

Frontiers in Marine Science

Received: 31 October 2018

Accepted: 05 July 2019

Published: 08 August 2019

Citation:

Todd RE, Chavez FP, Clayton S,

Cravatte $S$, Goes $M$, Graco $M$, Lin X, Sprintall J, Zilberman NV, Archer M, Arístegui J, Balmaseda M, Bane JM,

Baringer MO, Barth JA, Beal LM, Brandt P, Calil PHR, Campos E

Centurioni LR, Chidichimo MP

Cirano M, Cronin MF, Curchitser EN,

Davis RE, Dengler M, deYoung $B$,

Dong S, Escribano R, Fassbender AJ,

Fawcett SE, Feng M, Goni GJ,

Gray $A R$, Gutiérrez $D$, Hebert $D$,

Hummels $R$, Ito $S$-i, Krug M, Lacan F,

Laurindo L, Lazar A, Lee CM,

Lengaigne $M$, Levine NM,

Middleton J, Montes I, Muglia M,

Nagai T, Palevsky HI, Palter JB,

Phillips HE, Piola A, Plueddemann AJ,

Qiu B, Rodrigues RR, Roughan M,

Rudnick DL, Rykaczewski RR,

Saraceno M, Seim H, Sen Gupta A,

Shannon L, Sloyan BM, Sutton AJ,

Thompson L, van der Plas AK,

Volkov $D$, Wilkin J, Zhang $D$ and

Zhang L (2019) Global Perspectives

on Observing Ocean Boundary

Current Systems.

Front. Mar. Sci. 6:423.

doi: 10.3389/fmars.2019.00423
Robert E. Todd ${ }^{*}$, Francisco P. Chavez ${ }^{2}$, Sophie Clayton ${ }^{3}$, Sophie Cravatte Marlos Goes ${ }^{5,6}$, Michelle Graco ${ }^{7}$, Xiaopei Lin ${ }^{8}$, Janet Sprintall', Nathalie V. Zilberman ${ }^{9}$, Matthew Archer ${ }^{10}$, Javier Arístegui ${ }^{11}$, Magdalena Balmaseda ${ }^{12}$, John M. Bane ${ }^{13}$, Molly O. Baringer ${ }^{5}$, John A. Barth ${ }^{14}$, Lisa M. Beal ${ }^{6}$, Peter Brandt ${ }^{15,16}$, Paulo H. R. Calil17, Edmo Campos $^{18}$, Luca R. Centurioni ${ }^{9}$, Maria Paz Chidichimo ${ }^{19}$, Mauro Cirano ${ }^{20}$, Meghan F. Cronin ${ }^{21}$, Enrique N. Curchitser ${ }^{22}$, Russ E. Davis ${ }^{9}$, Marcus Dengler ${ }^{15}$, Brad deYoung ${ }^{23}$, Shenfu Dong ${ }^{5}$, Ruben Escribano ${ }^{24}$, Andrea J. Fassbender ${ }^{2}$, Sarah E. Fawcett ${ }^{25}$, Ming Feng ${ }^{26}$, Gustavo J. Goni ${ }^{5}$, Alison R. Gray ${ }^{27}$, Dimitri Gutiérrez ${ }^{7}$, Dave Hebert ${ }^{28}$, Rebecca Hummels ${ }^{15}$, Shin-ichi Ito $^{29}$, Marjorlaine Krug ${ }^{30}$, François Lacan ${ }^{4,31}$, Lucas Laurindo ${ }^{6}$, Alban Lazar ${ }^{32}$, Craig M. Lee ${ }^{33}$, Matthieu Lengaigne ${ }^{32}$, Naomi M. Levine ${ }^{34}$, John Middleton ${ }^{35}$, Ivonne Montes ${ }^{36}$, Mike Muglia ${ }^{13,37}$, Takeyoshi Nagai ${ }^{38}$, Hilary I. Palevsky ${ }^{39}$, Jaime B. Palter ${ }^{40}$, Helen E. Phillips ${ }^{41}$, Alberto Piola19,42, Albert J. Plueddemann11, Bo Qiu'43, Regina R. Rodrigues ${ }^{44}$, Moninya Roughan ${ }^{45}$, Daniel L. Rudnick ${ }^{9}$, Ryan R. Rykaczewski ${ }^{46}$, Martin Saraceno ${ }^{42,47}$, Harvey Seim ${ }^{13}$, Alex Sen Gupta ${ }^{45}$, Lynne Shannon ${ }^{48}$, Bernadette M. Sloyan ${ }^{49}$, Adrienne J. Sutton ${ }^{21}$, LuAnne Thompson ${ }^{27}$, Anja K. van der Plas ${ }^{50}$, Denis Volkov, ${ }^{5,6}$, John Wilkin ${ }^{51}$, Dongxiao Zhang ${ }^{21,52}$ and Linlin Zhang ${ }^{53}$

${ }^{1}$ Woods Hole Oceanographic Institution, Woods Hole, MA, United States, ${ }^{2}$ Monterey Bay Aquarium Research Institute, Moss Landing, CA, United States, ${ }^{3}$ Department of Ocean, Earth, and Atmospheric Sciences, Old Dominion University, Norfolk, VA, United States, ${ }^{4}$ LEGOS, IRD, CNES, CNRS, UPS, Universite de Toulouse, Toulouse, France, ${ }^{5}$ NOAA's Atlantic Oceanographic and Meteorological Laboratory, Miami, FL, United States, ${ }^{6}$ Rosenstiel School of Marine and Atmospheric Science, University of Miami, Miami, FL, United States, ${ }^{7}$ Instituto del Mar del Peru, Lima, Peru, ${ }^{8}$ Qingdao National Laboratory for Marine Science and Technology, Ocean University of China, Qingdao, China, ${ }^{9}$ Scripps Institution of Oceanography, University of California, San Diego, La Jolla, CA, United States, ${ }^{10}$ Jet Propulsion Laboratory, California Institute of Technology, Pasadena, CA, United States, ${ }^{11}$ Instituto de Oceanografía y Cambio Global, Universidad de Las Palmas de Gran Canaria, Las Palmas, Spain, ${ }^{12}$ European Centre for Medium-Range Weather Forecasts, Reading, United Kingdom, ${ }^{13}$ Department of Marine Sciences, The University of North Carolina at Chapel Hill, Chapel Hill, NC, United States, ${ }^{14}$ College of Earth, Ocean, and Atmospheric Sciences, Oregon State University, Corvallis, OR, United States, ${ }^{15}$ GEOMAR Helmholtz Centre for Ocean Research Kiel, Kiel, Germany, ${ }^{16}$ Faculty of Mathematics and Natural Sciences, Kiel University, Kiel, Germany, ${ }^{17}$ Institute of Coastal Research, Helmholtz-Zentrum Geesthacht, Geesthacht, Germany, ${ }^{18}$ Departamento de Oceanografia Física, Química e Geológica University of São Paulo, São Paulo, Brazil, ${ }^{19}$ Consejo Nacional de Investigaciones Cientificas y Técnicas, Servicio de Hidrografía Naval, Buenos Aires, Argentina, ${ }^{20}$ Department of Meteorology, Institute of Geosciences, Federal University of Rio de Janeiro (UFRJ), Rio de Janeiro, Brazil, ${ }^{21}$ NOAA Pacific Marine Environmental Laboratory, Seattle, WA, United States, ${ }^{22}$ Deptartment of Environmental Science, Rutgers University, New Brunswick, NJ, United States, ${ }^{23}$ Department of Physics and Physical Oceanography, Memorial University of Newfoundland, St. John's, NL, Canada, ${ }^{24}$ Instituto Milenio de Oceanografía, Universidad de Concepción, Concepción, Chile, ${ }^{25}$ Department of Oceanography, University of Cape Town, Cape Town, South Africa, ${ }^{26}$ CSIRO Oceans and Atmosphere, Crawley, WA, Australia, ${ }^{27}$ School of Oceanography, University of Washington, Seattle, WA, United States, ${ }^{28}$ Fisheries and Oceans Canada, Dartmouth, NS, Canada, ${ }^{29}$ Atmosphere and Ocean Research Institute, The University of Tokyo, Kashiwa, Japan, ${ }^{30}$ Council for Scientific and Industrial Research, Cape Town, South Africa, ${ }^{31}$ LEGOS, CNRS, CNES, UPS, University of Toulouse, Toulouse, France, ${ }^{32}$ LOCEAN-IPSL, Sorbonne Université, Paris, France, ${ }^{33}$ Applied Physics Laboratory, University of Washington, Seattle, WA, United States, ${ }^{34}$ Department of Biological Sciences, University of Southern California, Los Angeles, CA, United States, ${ }^{35}$ South Australian Research and Development Institute (Aquatic Sciences), West Beach, SA, Australia, ${ }^{36}$ Instituto Geofísico del Perú, Lima, Peru, ${ }^{37}$ UNC Coastal Studies Institute, Wanchese, NC, United States, ${ }^{38}$ Tokyo University of Marine Science and Technology, Tokyo, Japan, ${ }^{39}$ Wellesley College, Wellesley, MA, United States, ${ }^{40}$ Graduate School of Oceanography, University of Rhode Island, Narragansett, RI, United States, ${ }^{41}$ Institute for Marine and Antarctic Studies, University of Tasmania, Hobart, TAS, Australia, ${ }^{42}$ Departamento de Ciencias de la Atmósfera y los Oceanos, University of Buenos Aires, Buenos Aires, Argentina, ${ }^{43}$ School of Ocean and Earth Science and Technology, University of Hawai'i at Mānoa, Honolulu, HI, United States, ${ }^{44}$ Departamento de Oceanografia, Universidade Federal de Santa Catarina, Florianópolis, Brazil, ${ }^{45}$ School of Mathematics and Statistics, University of New South Wales, Sydney, NSW, Australia, ${ }^{46}$ Department of Biological Sciences, University of South Carolina, Columbia, SC, United States, ${ }^{47}$ Consejo Nacional de Investigaciones Cientificas y Técnicas, Buenos Aires, Argentina, 


\begin{abstract}
${ }^{48}$ Department of Biological Sciences, University of Cape Town, Cape Town, South Africa, ${ }^{49}$ CSIRO Oceans and Atmosphere, Hobart, TAS, Australia, ${ }^{50}$ Ministry of Fisheries and Marine Resources, Swakopmund, Namibia, ${ }^{51}$ Department of Marine and Coastal Sciences, Rutgers University, New Brunswick, NJ, United States, ${ }^{52}$ Joint Institute for the Study of the Atmosphere and Ocean, University of Washington, Seattle, WA, United States, ${ }^{53}$ Institute of Oceanology, Chinese Academy of Sciences, Qingdao, China
\end{abstract}

Ocean boundary current systems are key components of the climate system, are home to highly productive ecosystems, and have numerous societal impacts. Establishment of a global network of boundary current observing systems is a critical part of ongoing development of the Global Ocean Observing System. The characteristics of boundary current systems are reviewed, focusing on scientific and societal motivations for sustained observing. Techniques currently used to observe boundary current systems are reviewed, followed by a census of the current state of boundary current observing systems globally. The next steps in the development of boundary current observing systems are considered, leading to several specific recommendations.

Keywords: western boundary current systems, eastern boundary current systems, ocean observing systems, time series, autonomous underwater gliders, drifters, remote sensing, moorings

\section{INTRODUCTION}

Ocean boundary current systems are where society most frequently interacts with the ocean through fisheries, maritime transportation, oil and gas extraction, and recreation. These systems are home to intense and highly variable oceanic currents that redistribute mass, heat, salt, biogeochemical constituents, plankton, and pollution. Circulation patterns also influence the life history, foraging behavior, and abundance of many marine species (e.g., Mansfield et al., 2017). The coastal and open oceans are linked through boundary current systems where events such as coastal upwelling, sea level anomalies, primary productivity, fisheries, and weather are propagated between domains by various processes (e.g., eddies, Rossby waves, and advection). Boundary currents may be broadly categorized as either western boundary currents (WBCs; Imawaki et al., 2013) or eastern boundary currents (EBCs) based on their governing dynamics. In each ocean basin, WBCs play a prominent role in the climate system by redistributing heat from the equator toward the poles, while EBCs are some of the most biologically productive regions in the world and respond dramatically to climate variability (Chavez et al., 2008; Chavez and Messié, 2009).

In our changing climate, shifting hydrological cycles and weather patterns are expected to strongly impact oceanic boundary current processes. Observational evidence for such shifts is beginning to appear. Wu et al. (2012) noted enhanced warming of subtropical WBCs and their extensions during the 20th century, possibly linked to their poleward shift or intensification. Changes in the stability of WBCs have also been noted, with instabilities in the Gulf Stream shifting westward (Andres, 2016), increasing influence of warm core rings on shelf circulation (Gawarkiewicz et al., 2018), and a trend toward greater instability in the East Australian and Agulhas Currents (Sloyan and O'Kane, 2015; Beal and Elipot, 2016).

Oceanic ecosystems are being exposed to increasing pressure from major stressors including warming, deoxygenation, fishing, and acidification. EBCs in particular are projected to be strongly impacted by these stressors (Bakun et al., 2015). For instance, the Peru-Chile (Humboldt) Current system (see the section Peru-Chile Current System), a highly productive EBC and a regional source of greenhouse gases, is naturally affected by upwelling of offshore waters with low oxygen and $\mathrm{pH}$ onto the continental shelf (Helly and Levin, 2004) and by periodic El Niño Southern Oscillation (ENSO) events that change the water mass distributions, oxygenation, and productivity (Chavez et al., 2008; Gutiérrez, 2016; Graco et al., 2017); further, stress could have significant consequences for the regional ecosystem. Similarly, changes in the Gulf Stream under global warming are predicted to negatively impact fisheries in the Gulf of Maine and on the New England Shelf (Saba et al., 2016; Claret et al., 2018).

Sustained, interdisciplinary observations in boundary current regions are required for a comprehensive ocean observing system. For OceanObs'09, Send et al. (2010) proposed a global network of sustained monitoring arrays as part of the Global Ocean Observing System (GOOS). Send et al. (2010) broadly defined the properties to be observed as (1) the transports of mass, heat, and freshwater needed for monitoring the global climate in conjunction with basin-scale measurements and (2) local boundary-specific properties including eddy activity, changes in potential vorticity, air-sea interactions (Cronin et al., 2019), ecosystem dynamics, and biogeochemistry. More recently, the 2017 GOOS workshop on "Implementation of Multi-Disciplinary Sustained Ocean Observations" (IMSOO; Palacz et al., 2017) focused, in part, on how to proceed with the development of a truly multidisciplinary boundary current observing system, building upon the more physical and climatefocused plans of Send et al. (2010). In particular, it was noted that observations that resolve along-boundary variability are needed in order to understand climate impacts on various societally relevant uses of boundary current systems (e.g., fisheries). The need to maintain a global perspective that targets all boundary current systems has been repeatedly recognized (Send et al., 2010; Palacz et al., 2017), particularly in developing nations where fisheries can be centrally important (Palacz et al., 2017). To that end, IMSOO planned to review established observing systems in 
the California Current System and East Australian Current in order to develop a blueprint for an adaptive, multidisciplinary observing system with relocatable subsystems to capture finer scales (Palacz et al., 2017).

Oceanic boundaries present a variety of challenges for sustained observing systems (Send et al., 2010). With strong flows in relatively shallow areas, spatial scales of $\mathrm{O}(1)-\mathrm{O}(10) \mathrm{km}$, and temporal scales often shorter than a few days (e.g., He et al., 2010; Todd et al., 2013; Rudnick et al., 2017), the broad-scale (i.e., Argo and gridded satellite altimetry) and long-duration (e.g., HOTS, BATS, Station P, and CARIACO) measurements that constitute the observing system for the ocean interior are insufficient for boundary current systems. Multiple observing strategies are needed to measure the essential ocean variables (EOVs; Table 1) that can be used to understand and track the physical and biogeochemical processes of interest within boundary currents (Lindstrom et al., 2012). The optimal combination of observing methods will depend upon characteristics unique to each region. Send et al. (2010) noted that an additional challenge in observing boundary current systems is that there is no well-defined offshore "end" of a boundary current but rather a temporally and spatially variable transition to the interior. At the same time, oceanic boundaries generally lie within exclusive economic zones (EEZs), so the implementation of observing systems requires significant international cooperation.

The overarching purpose of this review is to examine the current state of the boundary current system component of GOOS, updating and building upon the OceanObs'09 review of Send et al. (2010). The section Scientific and Societal Needs considers the scientific and societal needs that comprehensive boundary current observing systems must fulfill. The section Observing Techniques reviews how various observing techniques are employed in boundary currents, highlighting key scientific advances from each platform. The section Current Status of Regional Boundary Current Observing Systems surveys the current state of boundary current observing systems globally. Table 2 provides a comprehensive collection of publications and datasets from the past decade, organized by region and platform. The section Future Outlook then considers the future development of boundary current observing systems. The section Summary Recommendations concludes with specific recommendations to promote development of a comprehensive global network of boundary current observing systems.

\section{SCIENTIFIC AND SOCIETAL NEEDS}

The Framework for Ocean Observing (Lindstrom et al., 2012), developed after OceanObs'09, recommended that ocean observing systems (1) be "fit for purpose" and driven by "scientific inquiry and societal needs"; (2) include physical, biogeochemical, and biological observations; (3) operate collaboratively based on established best practices; (4) balance innovation with stability; (5) promote alignment of independent user groups; (6) build on existing infrastructure as much as possible; and (7) provide maximum benefit to all users from each observation. Here, we present the scientific and societal needs that that should be met by comprehensive observing of oceanic boundary current systems, focusing on three broad categories: ecosystems and biogeochemistry (see the section Ecosystems and Biogeochemistry), weather and climate (see the section Climate and Weather), and connections between the shelves and deep ocean (see the section Shelf-Deep Ocean Connections).

\section{Ecosystems and Biogeochemistry}

Boundary current systems play an important role in carbon cycling through the physical and biological carbon pumps. WBCs are major sites of air-sea $\mathrm{CO}_{2}$ exchange (e.g., Rodgers et al., 2008; Gorgues et al., 2010; Nakano et al., 2011) and have been shown to exhibit enhanced contemporary carbon uptake from the atmosphere (Takahashi et al., 2009; Landschützer et al., 2014). $\mathrm{WBC} \mathrm{CO}_{2}$ uptake is driven by a large $\mathrm{pCO}_{2}$ disequilibrium with the overlying mid-latitude atmosphere, which is due to the rapid cooling of low Revelle factor waters advected from the tropics to midlatitudes. Since thick subtropical mode waters form during wintertime convection on the equatorward edges of the WBC extensions, the mode waters are key carbon sinks (e.g., Bates et al., 2002; Gruber et al., 2002; Ito and Follows, 2003; Levine et al., 2011; DeVries, 2014; Iudicone et al., 2016) and have been the target of detailed observational carbon studies (Andersson et al., 2013; Palevsky and Quay, 2017). However, it is still unclear how variability in the rate of mode water formation might impact ocean carbon uptake in these regions and what impacts these changes might have on the biological pump and higher trophic levels (e.g., fisheries). In the Kuroshio Extension region, there is evidence that the majority of carbon exported from the surface ocean during the spring and summer productive season is subsequently respired in the seasonal thermocline and ventilated back to the atmosphere during wintertime mode water formation (Palevsky et al., 2016; Fassbender et al., 2017b; Palevsky and Quay, 2017; Bushinsky and Emerson, 2018). The Southern Hemisphere WBCs are chronically undersampled, particularly during winter, leading to significant uncertainty in their contribution to the global ocean carbon sink.

Boundary current systems are highly productive regions (Chavez et al., 2008). The mechanisms of nutrient supply to surface waters that drive increased primary productivity differ among EBC and WBC systems, but their global contributions are similar (Chavez and Toggweiler, 1995). In EBC systems, the dominant source of nutrients is coastal upwelling (Chavez and Messié, 2009), while in WBC systems, geostrophic- and eddydriven upwelling predominates (Pelegrí and Csanady, 1991). Nutrient streams are important in the Gulf Stream (Pelegrí and Csanady, 1991; Pelegrí et al., 1996; Williams et al., 2006, 2011; Palter and Lozier, 2008) and the Kuroshio (Guo et al., 2012, 2013), transporting subsurface positive nitrate anomalies, which are delivered to the photic zone primarily by mesoscale and submesoscale processes (Nagai and Clayton, 2017; Honda et al., 2018; Yamamoto et al., 2018; Zhang et al., 2018). Nutrient cycles and drivers have not yet been studied in WBC systems of the Southern Hemisphere.

Western boundary currents are also enriched in micronutrients (e.g., Fe, Zn, Cd, Co, and Ni) from land-sea exchanges. They ultimately feed open ocean surface waters and, at lower 
TABLE 1 | List of essential ocean variables from www.goosocean.org/eov with indications of which observing platforms are able to sample each variable.

\begin{tabular}{|c|c|c|c|c|c|c|c|c|c|c|c|c|}
\hline & & $\begin{array}{c}\text { Autonomous } \\
\text { Underwater } \\
\text { Gliders }\end{array}$ & Drifters & Moorings & $\begin{array}{l}\text { Profiling } \\
\text { Floats }\end{array}$ & $\begin{array}{l}\text { Satellite } \\
\text { Remote } \\
\text { Sensing }\end{array}$ & $\begin{array}{l}\text { High- } \\
\text { Frequency } \\
\text { Radar }\end{array}$ & $\begin{array}{c}\text { Ships of } \\
\text { Opportunity }\end{array}$ & $\begin{array}{l}\text { Research } \\
\text { Ships }\end{array}$ & $\begin{array}{c}\text { Expendable } \\
\text { Bathythermographs }\end{array}$ & $\begin{array}{l}\text { Inverted } \\
\text { Echo } \\
\text { Sounders }\end{array}$ & $\begin{array}{c}\text { Submarine } \\
\text { Cables }\end{array}$ \\
\hline \multirow[t]{11}{*}{ Physics } & Sea state & & $x$ & $x$ & & $x$ & & $x$ & $x$ & & & \\
\hline & Ocean surface stress & & & $x$ & & $x$ & & & $x$ & & & \\
\hline & Sea ice & & & $x$ & & $x$ & & & $x$ & & & \\
\hline & Sea surface height & & & & & $x$ & & & & & & \\
\hline & Sea surface temperature & $x$ & $x$ & $x$ & $x$ & $x$ & & $x$ & $x$ & $x$ & & \\
\hline & Subsurface temperature & $x$ & & $x$ & $x$ & & & & $x$ & $x$ & $x$ & \\
\hline & Surface currents & $x$ & $x$ & $x$ & $x$ & $x$ & $x$ & $x$ & $x$ & & & \\
\hline & Subsurface currents & $x$ & & $x$ & $x$ & & & $x$ & $x$ & & $x$ & $x$ \\
\hline & Sea surface salinity & $x$ & & $x$ & $x$ & $x$ & & $x$ & $x$ & & & \\
\hline & Subsurface salinity & $x$ & & $x$ & $x$ & & & & $x$ & & & \\
\hline & Ocean surface heat flux & & & $x$ & & $x$ & & & $x$ & & & \\
\hline \multirow[t]{9}{*}{ Biogeochemistry } & Oxygen & $x$ & & $x$ & $x$ & & & $x$ & $x$ & & & \\
\hline & Nutrients & $x$ & & $x$ & & & & $x$ & $x$ & & & \\
\hline & Inorganic carbon & & & $x$ & & & & $x$ & $x$ & & & \\
\hline & Transient tracers & & & $x$ & & & & & $x$ & & & \\
\hline & Particulate matter & $x$ & & $x$ & & & & $x$ & $x$ & & & \\
\hline & Nitrous oxide & & & $x$ & & & & & $x$ & & & \\
\hline & Stable carbon isotopes & & & & & & & $x$ & $x$ & & & \\
\hline & Dissolved organic carbon & & & & & & & & $x$ & & & \\
\hline & Ocean color & & & & & $x$ & & & & & & \\
\hline \multirow[t]{11}{*}{$\begin{array}{l}\text { Biology and } \\
\text { Ecosystems }\end{array}$} & $\begin{array}{l}\text { Phytoplankton biomass } \\
\text { and diversity }\end{array}$ & $x$ & $x$ & $x$ & $x$ & $x$ & & $x$ & $x$ & & & \\
\hline & $\begin{array}{l}\text { Zooplankton biomass and } \\
\text { diversity }\end{array}$ & $x$ & & $x$ & & & & & $x$ & & & \\
\hline & $\begin{array}{l}\text { Fish abundance and } \\
\text { distribution }\end{array}$ & $x$ & & $x$ & & & & & $x$ & & & \\
\hline & $\begin{array}{l}\text { Marine turtles, birds, and } \\
\text { mammals abundance and } \\
\text { distribution }\end{array}$ & & & $x$ & & & & & $x$ & & & \\
\hline & $\begin{array}{l}\text { Hard coral cover and } \\
\text { composition }\end{array}$ & & & & & & & & $x$ & & & \\
\hline & Seagrass cover & & & & & & & & $x$ & & & \\
\hline & Macroalgal canopy cover & & & & & & & & $x$ & & & \\
\hline & Mangrove cover & & & & & & & & $x$ & & & \\
\hline & Ocean sound & $x$ & & $x$ & & & & & $x$ & & & \\
\hline & $\begin{array}{l}\text { Microbe biomass and } \\
\text { diversity ( }{ }^{*} \text { emerging) }\end{array}$ & & & & & & & & $x$ & & & \\
\hline & $\begin{array}{l}\text { Benthic invertebrate } \\
\text { abundance and distribution } \\
\text { (*emerging) }\end{array}$ & & & & & & & & $x$ & & & \\
\hline
\end{tabular}


TABLE 2 | Examples of sustained boundary current observing efforts since 2009

\begin{tabular}{|c|c|c|}
\hline Region & Platform & References \\
\hline Agulhas & Gliders & Krug et al., 2017 \\
\hline Agulhas & Moorings & $\begin{array}{l}\text { Beal et al., 2015; Elipot and Beal, 2015, 2018; Beal and } \\
\text { Elipot, 2016; Kersalé et al., } 2018\end{array}$ \\
\hline Agulhas & XBT & \\
\hline Angola Current & Moorings & Kopte et al., 2017, 2018; Tchipalanga et al., 2018 \\
\hline Benguela Current & Argo & Pegliasco et al., 2015; Majumder and Schmid, 2018 \\
\hline Benguela Current & Research Vessels & \\
\hline Benguela Current & Moorings & Junker et al., 2017a, 2019 \\
\hline Brazil Current & Drifters & Oliveira et al., 2009 \\
\hline Brazil Current & Moorings & Meinen et al., 2017, 2018 \\
\hline Brazil Current & Research Vessels & Valla et al., 2018 \\
\hline Brazil Current & XBT & $\begin{array}{l}\text { Garzoli et al., 2012; Mata et al., 2012; Lima et al., 2016; } \\
\text { Majumder et al., } 2019\end{array}$ \\
\hline Brazil Current & Argo & Schmid and Majumder, 2018 \\
\hline North Brazil Undercurrent & Moorings & Hummels et al., 2015 \\
\hline California Current System & Drifters & \\
\hline California Current System & Gliders & $\begin{array}{l}\text { Todd et al., 2011a,b, 2012; Pelland et al., 2013; Mazzini } \\
\text { et al., 2014; Johnston and Rudnick, 2015; Adams et al., } \\
\text { 2016; Zaba and Rudnick, 2016; Rudnick et al., 2017; } \\
\text { Henderikx Freitas et al., } 2018\end{array}$ \\
\hline California Current System & High-Frequency Radar & Kim, 2010; Kim et al., 2011; Kim and Kosro, 2013; \\
\hline California Current System & Moorings & $\begin{array}{l}\text { Nam et al., 2011; Harris et al., 2013; Ohman et al., 2013; } \\
\text { Sutton et al., 2014, 2016; Fassbender et al., 2016, 2017a, } \\
\text { 2018; Siedlecki et al., } 2016\end{array}$ \\
\hline California Current System & Research Vessels & $\begin{array}{l}\text { Juranek et al., 2009; Fassbender et al., 2011, 2017a, 2018; } \\
\text { Alin et al., 2012; Bednaršek et al., 2014, 2017, 2018; } \\
\text { McClatchie, 2014; Reum et al., 2014, 2016; Feely et al., } \\
\text { 2016, 2018; McClatchie et al., } 2016\end{array}$ \\
\hline California Current System & Ship of Opportunity & Fassbender et al., 2018 \\
\hline California Current System & XBT & Douglass et al., 2010; Auad et al., 2011 \\
\hline California Current System & Argo & Pegliasco et al., 2015 \\
\hline East Auckland Current & XBT & Bowen et al., 2017; Fernandez et al., 2018 \\
\hline
\end{tabular}

Data source

http://www.aoml.noaa.gov/phod/research/moc/samoc/sam/;

http://www.aoml.noaa.gov/phod/hdenxbt/index.php;

http://www-hrx.ucsd.edu

https://doi.org/10.1594/PANGAEA.868684;

https://doi.org/10.1594/PANGAEA.886492

http://www.argodatamgt.org

http://www.mfmr.gov.na/;

http://data.ocean.gov.za/pub/DATA;

https://doi.org/10.1594/PANGAEA.871251 (Junker et al., 2017b); https://doi.org/10.1594/PANGAEA.871253 (Junker et al., 2017C); https://doi.org/10.1594/PANGAEA.872098 (Junker et al., 2017d); https://doi.org/10.1594/PANGAEA.872099 (Junker et al., 2017e);

https://www.ocims.gov.za

http://www.aoml.noaa.gov/phod/gdp/index.php

http://www.aoml.noaa.gov/phod/SAMOC_international/samoc_data.php

http://www.aoml.noaa.gov/phod/hdenxbt/index.php

http://argodatamgt.org

https://doi.org/10.1594/PANGAEA.886415;

https://doi.org/10.1594/PANGAEA.886420;

https://doi.org/10.1594/PANGAEA.886426;

https://doi.org/10.1594/PANGAEA.886428

http://www.aoml.noaa.gov/phod/gdp/index.php

https://spraydata.ucsd.edu/projects/CUGN (Rudnick, 2016a);

https://spraydata.ucsd.edu/projects/CORC (Send, 2018);

http://www.oceanobservatories.org/

http://www.oceanobservatories.org/:

https://www.nodc.noaa.gov/ocads/oceans/Coastal/north_america_west.html;

$\mathrm{ftp}: / /$ data.ndbc.noaa.gov/data/oceansites/

http://www.calcofi.org;

https://www.nodc.noaa.gov/ocads/oceans/Coastal/north_america_west.html

http://www-hrx.ucsd.edu

http://www.argodatamgt.org

http://www-hrx.ucsd.edu 


\begin{tabular}{|c|c|c|c|}
\hline Region & Platform & References & Data source \\
\hline East Australian Current & Argo & Zilberman et al., 2014, 2018 & $\begin{array}{l}\text { https://portal.aodn.org.au; } \\
\text { http://www.argodatamgt.org }\end{array}$ \\
\hline East Australian Current & Drifters & Brassington, 2010; Brassington et al., 2011 & http://www.aoml.noaa.gov/phod/gdp/index.php \\
\hline East Australian Current & Gliders & $\begin{array}{l}\text { Roughan et al., 2015; Schaeffer and Roughan, 2015; } \\
\text { Schaeffer A. et al., 2016; Schaeffer A. M. et al., } 2016\end{array}$ & $\begin{array}{l}\text { https://portal.aodn.org.au; } \\
\text { http://imos.org.au/facilities/aodn/ }\end{array}$ \\
\hline East Australian Current & High-Frequency Radar & $\begin{array}{l}\text { Roughan et al., 2015; Archer et al., 2017a, 2018; Mantovanelli } \\
\text { et al., 2017; Schaeffer et al., 2017; Wyatt et al., } 2018\end{array}$ & $\begin{array}{l}\text { www.oceanography.unsw.edu.au/radar.html } \\
\text { https://portal.aodn.org.au }\end{array}$ \\
\hline East Australian Current & Moorings & $\begin{array}{l}\text { Roughan et al., 2013, 2015; Schaeffer et al., 2013, 2014; Lynch } \\
\text { et al., 2014; Sloyan et al., 2016; Schaeffer and Roughan, 2017; } \\
\text { Alford et al., } 2017\end{array}$ & https://portal.aodn.org.au \\
\hline East Australian Current & XBT & $\begin{array}{l}\text { Hill et al., 2011; Suthers et al., 2011; Sloyan and O'Kane, 2015; } \\
\text { Zilberman et al., 2018; }\end{array}$ & $\begin{array}{l}\text { https://portal.aodn.org.au; } \\
\text { http://www-hrx.ucsd.edu }\end{array}$ \\
\hline Gulf Stream & Gliders & $\begin{array}{l}\text { Todd et al., 2016, 2018b; Todd, 2017; Todd and Locke-Wynn, } \\
\text { 2017; Gula et al., } 2019\end{array}$ & https://spraydata.ucsd.edu/projects/GS (Todd and Owens, 2016) \\
\hline Gulf Stream & High-Frequency Radar & Parks et al., 2009; Archer et al., 2015, 2017b; Haines et al., 2017 & http://cordc.ucsd.edu/projects/mapping/maps/ \\
\hline Gulf Stream & Moorings & $\begin{array}{l}\text { Weller et al., 2012; Bigorre et al., 2013; Bane et al., 2017; } \\
\text { Lowcher et al., } 2017\end{array}$ & http://www.whoi.edu/science/PO/linew/ \\
\hline Gulf Stream & Research Vessels & Meinen et al., 2010 & $\begin{array}{l}\text { http://www.aoml.noaa.gov/phod/floridacurrent/; } \\
\text { http://www.whoi.edu/science/PO/linew/ }\end{array}$ \\
\hline Gulf Stream & Ship of Opportunity & Rossby et al., 2010; Wang et al., 2010 & http://oleander.bios.edu/ \\
\hline Gulf Stream & XBT & Domingues et al., 2018 & http://www.aoml.noaa.gov/phod/hdenxbt/index.php \\
\hline Gulf Stream & Submarine Cable & Meinen et al., 2010 & http://www.aoml.noaa.gov/phod/floridacurrent/ \\
\hline Kuroshio & Argo & $\begin{array}{l}\text { Sugimoto and Hanawa, 2014; Oka et al., 2015; Bushinsky et al., } \\
\text { 2016; Inoue et al., 2016a,b; Fassbender et al., 2017b; Bushinsky } \\
\text { and Emerson, } 2018\end{array}$ & http://www.argodatamgt.org \\
\hline Kuroshio & HF Radar & Yang et al., 2015 & \\
\hline Kuroshio & Drifters & Vélez-Belchí et al., 2013; Gordon et al., 2014; Andres et al., 2015 & http://www.aoml.noaa.gov/phod/gdp/index.php \\
\hline Kuroshio & Gliders & $\begin{array}{l}\text { Rudnick et al., 2011, 2013; Johnston et al., 2013; Rainville et al., } \\
\text { 2013; Lien et al., 2014, } 2015\end{array}$ & \\
\hline Kuroshio & Moorings & $\begin{array}{l}\text { Bond et al., 2011; Cronin et al., 2013, 2015; Hu et al., 2013; } \\
\text { Wada et al., 2013; Lien et al., 2014, 2015; Sutton et al., 2014, } \\
\text { 2016, 2017; Zhou et al., 2014; Chen et al., 2015; Yang et al., } \\
\text { 2015; Zhang et al., 2015; Fassbender et al., 2017b; Honda et al., } \\
\text { 2018 }\end{array}$ & $\begin{array}{l}\text { https://www.nodc.noaa.gov/ocads/oceans/Moorings/Pacific.html; } \\
\text { ftp://data.ndbc.noaa.gov/data/oceansites }\end{array}$ \\
\hline Kuroshio & Research Vessels & $\begin{array}{l}\text { Yasunaka et al., 2013, 2014; Sugimoto and Hanawa, 2014; } \\
\text { Nakano et al., 2015; Yang et al., 2015; Oka et al., } 2018\end{array}$ & \\
\hline Kuroshio & Ship of Opportunity & Palevsky et al., 2016; Palevsky and Quay, 2017 & \\
\hline Kuroshio & XBT & Nagano et al., 2016 & http://www-hrx.ucsd.edu \\
\hline Labrador Current & Gliders & deYoung et al., 2018; Howatt et al., 2018 & \\
\hline
\end{tabular}




\begin{tabular}{|c|c|c|c|}
\hline Region & Platform & References & Data source \\
\hline Labrador Current & Moorings & deYoung et al., 2018 & \\
\hline Leeuwin Current & Gliders & Pattiaratchi et al., 2011 & \\
\hline Leeuwin Current & Argo & Furue et al., 2017 & http://www.argodatamgt.org \\
\hline Leeuwin Current & High-Frequency Radar & Mihanoviæ et al., 2016 & \\
\hline Leeuwin Current & Moorings & Lynch et al., 2014; & \\
\hline Loop Current (Gulf of Mexico) & Gliders & Gopalakrishnan et al., 2013; Rudnick et al., 2015a; Todd et al., 2016 & https://spraydata.ucsd.edu/projects/GoM (Rudnick, 2017) \\
\hline Malvinas Current & Argo & Artana et al., 2016, 2018b & http://www.argodatamgt.org \\
\hline Malvinas Current & Moorings & $\begin{array}{l}\text { Valla and Piola, 2015; Ferrari et al., 2017; Artana et al., 2018a; Paniagua } \\
\text { et al., } 2018\end{array}$ & $\begin{array}{l}\text { https://doi.org/10.17882/51492 (Saraceno et al., 2017); } \\
\text { https://www.seanoe.org/data/00403/51479/; } \\
\text { https://www.seanoe.org/data/00403/51492/ }\end{array}$ \\
\hline Mediterranean & Gliders & Heslop et al., 2012 & \\
\hline Middle Atlantic Bight & Gliders & $\begin{array}{l}\text { Castelao et al., 2010; Todd et al., 2013; Zhang and Gawarkiewicz, } \\
\text { 2015; Dever et al., 2016; Gawarkiewicz et al., } 2018\end{array}$ & http://www.oceanobservatories.org/ \\
\hline Middle Atlantic Bight & Moorings & Chen et al., 2018; Gawarkiewicz et al., 2018; Zhang and Partida, 2018 & http://www.oceanobservatories.org/ \\
\hline Mindanao & Gliders & Schönau et al., 2015; Schönau and Rudnick, 2017 & \\
\hline Mindanao & Moorings & Zhang et al., 2014; Hu et al., 2016; Wang et al., 2017 & \\
\hline NE Atlantic (Subpolar) & Gliders & Houpert et al., 2018 & \\
\hline Canary Current System & Drifters & Menna et al., 2016 & \\
\hline Canary Current System & Gliders & Karstensen et al., 2017; Kolodziejczyk et al., 2018 & \\
\hline Canary Current System & Mooring & Nowald et al., 2015 & http://www.fixo3.eu \\
\hline Canary Current System & Research Vessels & $\begin{array}{l}\text { Steinfeldt et al., 2015; Capet et al., 2017; Klenz et al., 2018; Machu } \\
\text { et al., 2019; Thomsen et al., } 2019\end{array}$ & \\
\hline Canary Current System & Argo & Pegliasco et al., 2015 & http://www.argodatamgt.org \\
\hline $\begin{array}{l}\text { NW Atlantic Deep Western } \\
\text { Boundary Current }\end{array}$ & Moorings & $\begin{array}{l}\text { Fischer et al., 2004, 2010; Dengler et al., 2006; Johns et al., 2008, 2011; } \\
\text { Bacon and Saunders, 2010; Toole et al., 2017; Zantopp et al., } 2017\end{array}$ & $\begin{array}{l}\text { http://www.whoi.edu/science/PO/linew/; } \\
\text { www.oceansites.org }\end{array}$ \\
\hline $\begin{array}{l}\text { NW Atlantic Deep Western } \\
\text { Boundary Current }\end{array}$ & Research Vessels & van Sebille et al., 2011 & http://www.whoi.edu/science/PO/linew/ \\
\hline Oyashio & Research Vessels & Kuroda et al., 2015, 2017 & http://tnfri.fra.affrc.go.jp/seika/a-line/a-line_index2.html \\
\hline Peru-Chile Current System & Gliders & Pietri et al., 2013, 2014; Pizarro et al., 2016 & \\
\hline Peru-Chile Current System & Argo & Pegliasco et al., 2015 & http://www.argodatamgt.org \\
\hline Peru-Chile Current System & Research Vessels & Espinoza et al., 2017; Graco et al., 2017; Grados et al., 2018 & \\
\hline Peru-Chile Current System & Research Vessels & Escribano and Morales, 2012; Schneider et al., 2016 & http://www.antares.ws \\
\hline Solomon Sea & Argo & Zilberman et al., 2013 & http://www.argodatamgt.org \\
\hline Solomon Sea & Gliders & Davis et al., 2012 & https://spraydata.ucsd.edu/projects/Solomon (Davis, 2016) \\
\hline Solomon Sea & Moorings & Ganachaud et al., 2014, 2017; Alberty, 2018 & $\begin{array}{l}\text { http://www.solomonseaoceanography.org/; } \\
\text { https://doi.org/10.6075/J09WOCS2 (Cravatte et al., 2019); } \\
\text { https://doi.org/10.6075/J0639N12 (Alberty et al., 2019) }\end{array}$ \\
\hline Solomon Sea & XBT & Zilberman et al., 2013 & http://www-hrx.ucsd.edu \\
\hline Somali Current & Drifters & Beal et al., 2013; Centurioni et al., 2017 & http://www.aoml.noaa.gov/phod/gdp/index.php \\
\hline South China Sea & Drifters & Centurioni et al., 2009 & http://www.aoml.noaa.gov/phod/gdp/index.php \\
\hline
\end{tabular}

Included are in situ and land-based observing efforts extending longer than 1 year in the period 2009-2018. Key references since 2009 and sources for publicly available data are included. 
latitudes, the equatorial undercurrent, where these micronutrients are critical in maintaining high levels of productivity. For instance, iron transported by boundary currents in the western Pacific feeds into the Pacific Equatorial Undercurrent, which then supplies iron to the eastern equatorial Pacific (e.g., Mackey et al., 2002; Ryan et al., 2006). In the North Atlantic, Gulf Stream rings supply iron to the subtropical gyre (e.g., Conway et al., 2018). Subpolar WBCs such as the Oyashio and Malvinas Currents are also likely to transport waters enriched in nutrients; wind-driven and shelfbreak upwelling then supplies nutrients to the euphotic layers, enhancing biological productivity (Matano and Palma, 2008; Ito et al., 2010; Valla and Piola, 2015). Locations at which subtropical and subpolar WBCs meet provide ideal environments for biological production, as warm subtropical waters converge with nutrient-rich subpolar waters (Brandini et al., 2000).

The upwelling of deep, poorly ventilated water masses rich in inorganic nutrients and $\mathrm{CO}_{2}$ and low in $\mathrm{O}_{2}$ make EBCs areas of high air-sea fluxes, and the sensitivity of the upwelling process to climate variability contributes to large interannual and decadal scale changes in the magnitude of these fluxes (Friederich et al., 2002; Brady et al., 2019). EBCs also exhibit strong cross-shore gradients in fluxes; narrow strips of the nearshore ocean act as intense sources of $\mathrm{CO}_{2}$ to the atmosphere, while the abundance of nutrients in these upwelled waters facilitates primary production that results in net uptake of $\mathrm{CO}_{2}$ (Hales et al., 2005). The supply of poorly ventilated waters combined with high levels of organic-matter remineralization resulting from intense primary production in surface waters can trigger periods of anoxia and low pH in shelf waters (Feely et al., 2008; Zhang et al., 2010) with severe consequences for demersal and pelagic ecosystems (Chan et al., 2008; Monteiro et al., 2008; Bertrand et al., 2011).

Boundary currents play an important role in ocean ecosystems across all trophic levels. The intense levels of primary production associated with EBCs support rich ecosystems with relatively short food chains, and these systems provide at least $20 \%$ of the world's wild-caught fish despite covering less than $1 \%$ of the global ocean (Chavez and Messié, 2009). WBCs and EBCs are also oceanic regions where coastal and open ocean ecosystems are brought together and interact. Modeling studies have suggested that boundary currents are hotspots of microbial biodiversity (Barton et al., 2010; Clayton et al., 2013). This has been supported in the Kuroshio Extension by some in situ surveys (Clayton et al., 2014, 2017). At the other end of the trophic spectrum, recent work combining tag data and satellite altimetry data has shown that white sharks (Carcharodon carcharias) actively occupy warm-core anticyclonic eddies in the Gulf Stream (Gaube et al., 2018). The warmer waters in these mesoscale features allow the sharks to reduce the physiological costs of thermoregulation in cold water, thereby making prey more accessible and energetically more profitable. Similarly, the location of the Kuroshio axis and associated changes in water temperature have been shown to influence the behavior of juvenile Pacific bluefin tuna (Thunnus orientalis; Fujioka et al., 2018). In the Southern Benguela EBC upwelling system, the coastal, wind-driven upwelling along the southwest African coast supports planktonic food supplies for young pelagic fish, while the temperate Agulhas
Bank shelf region provides suitable spawning habitat for large communities of fish including in particular anchovy and sardine (Hutchings et al., 2009a). Likewise, southern elephant seals feed along the intense fronts and eddies in the Brazil/Malvinas Confluence (Campagna et al., 2006). WBCs are also known to play an important role in the migration of other coastal and pelagic organisms, such as eels (Shinoda et al., 2011; Rypina et al., 2014) and salmon (Wagawa et al., 2016).

Marine heat waves (MHWs) are strongly linked with boundary current systems. For instance, the exceptional and devastating MHW event off Western Australia during summer of 2010/2011 was caused by a strengthening of the Leeuwin Current associated with La Niña conditions (Pearce and Feng, 2013; Feng et al., 2015), a 2014-2015 MHW had unprecedented impacts on the California Current System (Di Lorenzo and Mantua, 2016; Zaba and Rudnick, 2016), and an MHW in 2015-2016 impacted the Tasman Sea (Oliver et al., 2017). These discrete, prolonged periods of anomalously warm waters at particular locations (Hobday et al., 2016) can stress ecosystems, leading to increased mortality of marine species, closing of commercial and recreational fisheries, and coral bleaching (Cavole et al., 2016; Stuart-Smith et al., 2018). The addition of other stressors such as ocean acidification and deoxygenation, which are projected to increase in future warming scenarios, could amplify the ecosystem impacts of MHWs. Sustained physical and biogeochemical observations are necessary to improve forecasts of the frequency and magnitude of MHWs, as well as to assess the risk and vulnerability of marine ecosystems to extreme climate events (Frölicher and Laufkötter, 2018).

\section{Climate and Weather}

Boundary currents are an integral part of the global climate system as they redistribute heat and facilitate carbon uptake from the atmosphere (see the section Ecosystems and Biogeochemistry). In the Atlantic, boundary currents are key components of the Atlantic Meridional Overturning Circulation (AMOC; FrajkaWilliams et al., 2019). Low-latitude WBCs that connect the subtropics to the equator at thermocline and intermediate levels are important contributors to the mass and heat budgets of the equatorial oceans, which influence climate modes such as ENSO (Lengaigne et al., 2012). Low-latitude WBCs are also suspected to contribute to the decadal modulation of the equatorial thermocline background state (e.g., Lee and Fukumori, 2003). Sustained monitoring of WBC transports would be particularly useful for climate and seasonal-to-decadal forecast centers (see Smith et al., 2019).

As climate change progresses, boundary current systems are likely to undergo further significant changes. Subtropical WBCs and their extensions are the fastest warming regions of the world ocean (Wu et al., 2012; Yang et al., 2016). Climate model simulations have suggested that western boundary current extensions may move poleward under climate change (Saba et al., 2016). This poleward expansion of energetic WBCs may impact extreme temperatures and marine species migration (Johnson et al., 2011), as well as enhance eddy activity regionally (e.g., Oliver et al., 2015). While low-resolution climate models suggest strengthening and poleward migration of several of these currents 
under climate change, particularly in the Southern Hemisphere (Sen Gupta et al., 2012; Hu et al., 2015; Pontes et al., 2016), studies leveraging in situ velocity and satellite data suggest no significant increase in their transports since the early 1990s (Rossby et al., 2014; Beal and Elipot, 2016). This discrepancy motivates the collection of long-term measurements of baroclinic changes in boundary currents (i.e., subsurface temperature and salinity properties), as well as the vertical structure of the velocity, in order to understand and predict future changes.

In addition, ocean warming and a magnified hydrological cycle could drive significant changes in shelf ocean stratification, while changes to wind forcing will directly alter rates of upwelling. These ocean circulation processes, and meteorological forcing at the scales that impact upwelling, are poorly represented in climate models (Richter, 2015; Zuidema et al., 2016). Thus, we have little capability to predict how upwelling, winds, and other physical drivers of ocean property exchanges at the coastal/open ocean boundary will change in the future. The impact these changes will have on coastal ecosystems is simply unknown.

Detection and attribution of global sea level variability has improved considerably in the last decade (Cazenave et al., 2014; Marzeion et al., 2014). The location and strength of WBCs considerably influence the mean local sea level (Domingues et al., 2016; Archer et al., 2017b), possibly accounting for part of the mismatch between forecasts and observations of sea level at the coast (Ezer, 2015). Relationships between large-scale wind anomalies, basin-wide sea surface height (SSH), and WBCs (e.g., Boening et al., 2012; Volkov et al., 2019) suggest that observations of current strength and oceanic teleconnections can be used to improve seasonal to decadal coastal sea level forecasts, leading to improved assessments of impacts on infrastructure and groundwater quality (Slangen et al., 2014; Park and Sweet, 2015).

Boundary current systems influence synoptic and longer scale weather patterns. Large upper ocean heat content within WBCs can fuel development and intensification of tropical cyclones (Bright et al., 2002; Wu et al., 2008; Nguyen and Molinari, 2012; Galarneau et al., 2013). Strong sea surface temperature (SST) gradients across WBCs, particularly during winter months, destabilize the atmospheric boundary layer, fueling the midlatitude storm tracks and atmospheric blocking frequency, which in turn impact regional climate (Kelly et al., 2010; Nakamura, 2012; O’Reilly and Czaja, 2015; O’Reilly et al., 2016; Révelard et al., 2016; Ma et al., 2017). For instance, a weaker Gulf Stream SST front leads to a decrease in cold and dry spells over Europe (O'Reilly et al., 2016), while a sharper SST front in the Kuroshio Extension increases cyclogenesis and shifts the storm track northward, causing warming over eastern Asia and the western United States that can reduce snow cover by $4-6 \%$ (O'Reilly and Czaja, 2015; Révelard et al., 2016). Variability in the warm waters of the Agulhas influences summer rainfall over parts of South Africa (Jury et al., 1993; Nkwinkwa Njouodo et al., 2018). In EBC systems, SST minima are collocated with maxima in sea level pressure that are in turn associated with alongshore wind stress, wind stress curl, and cloud cover along the boundary (Sun et al., 2018), suggesting coupling with the full HadleyWalker tropical atmospheric circulation, though the details of such coupling remain an open question.
Accurate weather and climate forecasting thus requires accurate representation of boundary current systems. However, most of the current ocean reanalyses used to initialize the monthly, seasonal, and decadal forecasts exhibit large errors in the boundary currents (Rouault et al., 2003; Valdivieso et al., 2017), hampering forecast performance. Coupled climate models, such as those used in the Intergovernmental Panel on Climate Change reports, also exhibit large deficiencies in boundary current regions (e.g., Siqueira and Kirtman, 2016; Zuidema et al., 2016), including warm SST biases in EBCs (e.g., Large and Danabasoglu, 2006). Current modeling and data assimilation capabilities are insufficient to fully represent boundary currents at the small spatial scales needed for forecasting. Subramanian et al. (2019) further consider how observing efforts, including within boundary currents, can contribute to improved subseasonal-toseasonal forecasting.

\section{Shelf-Deep Ocean Connections}

The coastal ocean and nearshore zones support a broad range of human activities in maritime industries and resource extraction, and the environmental health and productivity of these regions deliver important ecosystem services. As already noted, the proximity of energetic boundary currents in deep water adjacent to continental shelves mediates shelf-sea/deep-ocean exchange of properties. Along many coasts, this forcing can match or exceed local drivers of circulation such as tides, wind, and river inflows. Coastal ocean and shelf edge dynamics have immediate impacts on ecosystem function and productivity on weekly to seasonal timescales but can also drive multi-decadal changes in ecosystem structure through effects on habitat ranges and biodiversity, not only in coastal zones but also at basin scales.

While we have a broad understanding of the dynamics of upwelling in both WBC and EBC regimes, quantitative estimates of net shelf-sea/deep-ocean exchanges of freshwater and tracers integrated over extended along-shelf distances are few. Quantifying these exchanges is challenging where shelf-edge flow-bathymetry interactions foster variability at short length and timescales. Similarly, exchange flows are not always readily observable at the sea surface from satellite or shore-based remote sensing technologies (see the section Remote Sensing) because they are associated with bottom boundary layer flow driven by the boundary current encountering the seafloor or subduction at the sea surface due to boundary current detachment and mixing. Two efforts along the U.S. East Coast are striving to make such measurements using multi-platform observing arrays: the Processes driving Exchange At Cape Hatteras (PEACH) program and the Ocean Observatories Initiative (OOI; Smith et al., 2018; Trowbridge et al., 2019) Pioneer Array (see the section Northwestern Atlantic). Similarly, in situ and satellite remote sensing observations combined with high-resolution numerical simulations have provided insights into the shelfsea/deep-ocean exchanges near the confluence of the Brazil and Malvinas Currents (Guerrero et al., 2014; Matano et al., 2014; Strub et al., 2015).

On narrow continental shelves adjacent to intense boundary currents, the impact of deep-ocean circulation on the shelf system is immediate, driving significant fluxes across the continental 
shelf edge through mesoscale and boundary layer dynamics. For example, mesoscale and submesoscale meandering of the Agulhas jet leads to strong episodic exchanges with shelf waters (Krug et al., 2017; Leber et al., 2017) that support high productivity over the eastern Agulhas Bank (Probyn et al., 1994) and may influence the well-known sardine run (Fréon et al., 2010). On broad continental shelves, bathymetric constraints on cross-isobath flow can hamper exchange at the shelf edge, trapping terrestrial inflows and establishing appreciable crossshelf buoyancy gradients that in turn sustain shelf-edge fronts (Fratantoni and Pickart, 2007; Howatt et al., 2018).

With changing climate, ocean warming and changes to the hydrological cycle could drive changes in vertical thermal stratification and across-shelf salinity stratification, altering ocean conditions at the inshore edge of boundary current systems (e.g., Gawarkiewicz et al., 2018) and potentially impacting across-shelf fluxes of nutrients and micro-nutrients that are important to sustaining coastal productivity (Fennel et al., 2006). Changes in watershed land use and global weather will alter the volume and characteristics of river flows discharged into the coastal zone. At continental shelf scales, key areas of uncertainty in the oceanographic response to climate variability and change include submesoscale processes and open oceanshelf exchange. Sustained observing efforts are needed that more fully capture the influence of boundary currents on exchanges with the coastal zone. Designing and deploying boundary current observing systems capable of operating across shelf and deep ocean regimes to deliver coherent views of the shelf-edge exchange is challenging.

\section{OBSERVING TECHNIQUES}

The highly variable and multi-scale characteristics of boundary currents necessitate an integrated observing system approach, in which high-resolution observations are nested within a backbone of observations over a broad area. Under the Framework for Ocean Observing (Lindstrom et al., 2012), design and implementation of ocean observing systems are focused around a set of EOVs that include physical, biogeochemical, and ecosystem parameters (Table 1) ${ }^{1}$. Design of an observing system for a particular region (e.g., a specific boundary current system) should proceed through a series of "readiness levels." In the concept phase, initial feasibility studies and peer review of proposed plans take place. Then, in the pilot phase, smallscale deployments are used to test and validate the proposed approach. Once the observing system reaches the mature phase, it is part of the sustained Global Ocean Observing System. No single observing platform can provide all of the necessary measurements (Table 1), so an optimal mix of observing platforms is needed. Determination of this mix of platforms will be specific to a particular boundary current system, taking into consideration the unique processes and scales at play in that system. Here, we briefly review how various observing platforms are currently being used in boundary current systems; Table 2

${ }^{1}$ http://www.goosocean.org/eov refers to many other examples of these observing techniques being applied to boundary current systems.

\section{Time Series}

Time series measured from platforms fixed to the seafloor have long been and continue to be central to observing system design and implementation since they uniquely enable collection of long-term measurements at high temporal resolution (minutes to hours) at key locations. Traditional tall moorings (e.g., Johns et al., 2005) typically carry instruments on the mooring wire, within subsurface floats, and on surface buoys, if present; instruments are available to measure most physical EOVs and a growing number of biogeochemical and ecosystem EOVs (Table 1). Moored surface buoys additionally carry suites of meteorological sensors on the buoy tower and sensors for biogeochemical and physical EOVs on the buoy bridle and mooring line just below the sea surface; these air- and seasurface measurements can be combined to estimate the air-sea exchanges of heat, moisture, $\mathrm{CO}_{2}$, and momentum (Cronin et al., 2019). Inverted echo sounders (IESs) measure the time for sound pulses to travel from the bottom-mounted IES to the surface and back, which, in regions with good databases of hydrographic measurements, can provide full water column estimates of temperature, salinity, and density using the gravest empirical mode technique (Meinen and Watts, 2000). In the Florida Strait, a unique time series of volume transport has resulted from measuring the voltage induced in a submarine cable by seawater moving through the Earth's magnetic field (Larsen and Sanford, 1985; Baringer and Larsen, 2001; Meinen et al., 2010).

Dense, moored arrays of instruments remain the most effective way to return volume and property transport measurements with high temporal resolution. Subsurface moorings are more typical in WBCs due to the strong surface currents, although surface moorings have also been successfully deployed in the Gulf Stream (Weller et al., 2012) and Kuroshio Extension (Cronin et al., 2013). Arrays of IESs can be used to infer geostrophic shear profiles and, with the addition of bottom pressure sensors (PIES) and near-bottom current measurements (CPIES), can provide estimates of the absolute geostrophic current (Donohue et al., 2010; Meinen et al., 2018). However, the high costs of building, deploying, and turning around such arrays makes them feasible only at a few key locations. Other observing assets are needed to provide spatially broad measurements.

\section{Ship-Based Measurements}

Measurements from both dedicated research vessels and ships of opportunity have been central to observing boundary current systems for decades. Research vessels can measure nearly every EOV (Table 1) through the full depth of the water column and are uniquely capable of collecting many types of samples (e.g., net tows and large-volume water samples). Ongoing sustained research vessel surveys of ocean boundary currents include the global GO-SHIP transects at 25- to $50-\mathrm{km}$ resolution (Talley et al., 2016) and the California Cooperative Oceanic Fisheries Investigations (CalCOFI) surveys (McClatchie, 2014) in the California Current System (see the section California Current System). The servicing of boundary current mooring arrays, 
generally undertaken from research vessels, provides unique opportunities to undertake intensive process studies targeting key scientific questions. The primary limitations on research vessels' contribution to sustained boundary current observing are their high costs of operation (typically tens of thousands of dollars per day, excluding science personnel) and the infrequency of cruises.

The World Meteorological Organization (WMO) Voluntary Observing Ship (VOS) Program and Ship of Opportunity Program (SOOP) both make use of non-research vessels to collect observations globally, substantially augmenting the amount of ship-based observing. Both programs collect meteorological measurements with real-time observations benefiting weather forecasting, while SOOP additionally uses commercial ships to collect oceanographic measurements along frequently occupied trade routes in the global ocean. Oceanic measurements from SOOP include temperature profiles from expendable bathythermographs (XBTs) at $10-$ to $25-\mathrm{km}$ resolution in boundary currents (Goni et al., 2019), surface temperature, salinity, plankton, and $\mathrm{pCO}_{2}$ from flow-through systems, and, on specially equipped vessels, velocity profiles from hull-mounted ADCPs (e.g., M/V Oleander; Rossby et al., 2010). Several repeat transects across boundary currents have been maintained for multiple decades and so represent some of the longer datasets available (see the section Current Status of Regional Boundary Current Observing Systems). Fast-moving ships are often able to occupy transects directly across strong boundary currents in short periods of time, a feat not yet possible with other sampling platforms. However, subsurface measurements of variables other than temperature and velocity have remained elusive from ships of opportunity, and recovery of instruments deployed over the side is not practical on cargo vessels.

\section{Autonomous Underwater Gliders}

Autonomous underwater gliders (Rudnick, 2016b; Testor et al., 2019) routinely collect long-duration, high-resolution observations in a variety of boundary current systems globally (Todd et al., 2018b; Table 2). Gliders typically profile from the surface to 500-1,000 m, taking 3-6 h to complete a cycle from the surface to depth and back while covering 3-6 km horizontally through the water at a speed of about $0.25 \mathrm{~m} \mathrm{~s}^{-1}$. During a mission lasting 3-6 months, a glider's survey track extends well over $2,000 \mathrm{~km}$. Owing to the relatively slow speed of gliders, care must be taken when interpreting the observations, which contain both spatial and temporal variability (Rudnick and Cole, 2011). Sustained deployment of networks of gliders can provide observations with both high spatial resolution and year-round coverage (e.g., Figures 1A,B).

Realizable glider-based sampling plans in boundary currents vary primarily due to the strength of currents relative to a glider's speed. In EBCs and other boundary currents with relatively weak depth-average currents, gliders can occupy repeat survey lines. The California Underwater Glider Network (CUGN; Figure 1, left), which consists of three cross-shore transects off southern and central California that have been continuously occupied for more than a decade (Rudnick et al., 2017), exemplifies sustained glider observations in an EBC. In WBCs and other boundary currents where depth-average currents are significantly faster than a glider's speed through the water, gliders can be navigated so as to cross the observed flow as they are advected downstream, returning oblique transects. For example, multi-year surveys of the Gulf Stream (Figure 1, right; Todd et al., 2016, 2018a; Todd, 2017; Todd and Locke-Wynn, 2017) have now returned over 150 high-resolution transects across the WBC of the North Atlantic. Testor et al. (2019) further discuss efforts associated with the OceanGliders Boundary Ocean Observing Network (BOON).

Gliders can carry a variety of sensors (e.g., Figures 1C-F). Measurements of pressure, temperature (Figure 1D), conductivity, and depth-average currents are standard, enabling estimates of absolute geostrophic transport and other physical parameters at relevant scales in boundary currents. Measurements of biooptical (e.g., Niewiadomska et al., 2008; Henderikx Freitas et al., 2016) and bio-acoustic properties (e.g., Baumgartner and Fratantoni, 2008; Van Uffelen et al., 2017), dissolved oxygen (e.g., Figure 1E; Perry et al., 2008), nitrate, turbulent microstructure (St. Laurent and Merrifield, 2017), and velocity profiles (Figure 1F; Todd et al., 2017) are becoming increasingly common. The main constraints on sensors for gliders are the requirements for small-size, low-power consumption and multimonth stability. As sensor technology continues to mature, gliders will be well suited to carry sensors for additional EOVs, such as $\mathrm{pH}$, in boundary currents.

\section{Drifters}

Surface Velocity Program (SVP) drifters drogued at 15-m depth (Niiler et al., 1995; Niiler, 2001; Centurioni, 2018) deployed as part of the Global Drifter Program (GDP) and the Global Surface Drifter Array (GSDA) are also important for understanding the structure and variability of boundary current systems. The GSDA archive dates back to February 1979 and includes over 32 million records of geographical location, 15-m depth velocity, and SST at 6-h resolution (e.g., Hansen and Poulain, 1996; Lumpkin and Pazos, 2007).

Drifter observations have been widely used in both EBCs and WBCs (see Table 2). Recently improved analysis techniques (e.g., Lumpkin, 2003; LaCasce, 2008; Koszalka and LaCasce, 2010; Laurindo et al., 2017) and expansion of the Lagrangian drifter array have allowed gridded, Eulerian statistics of nearsurface velocity to be produced at higher resolution, resulting in improved estimates of near-surface flow in boundary currents (e.g., Figure 2) at seasonal to interannual timescales (e.g., Niiler et al., 2003; Lumpkin and Johnson, 2013). Drifter observations in boundary currents offer opportunities for new analyses of long-term variability and trends (e.g., Johnson, 2001; Lumpkin and Johnson, 2013) and the dispersion of tracers and marine debris in the upper ocean (Lumpkin et al., 2012; van Sebille et al., 2015), which is driven by turbulence at scales from surface waves through the submesoscale to large-scale geostrophic eddies (Lumpkin et al., 2017; Lund et al., 2018).

\section{Argo Floats}

Over the past two decades, autonomous profiling Argo floats have become cost-effective and robust platforms. Over 3,700 active Argo floats provide global measurements of temperature, salinity, and pressure in the upper 2,000 $\mathrm{m}$ of the ocean, and some are also equipped with sensors measuring biogeochemical properties (Riser et al., 2016; Jayne et al., 2017; Roemmich et al., 2019). 


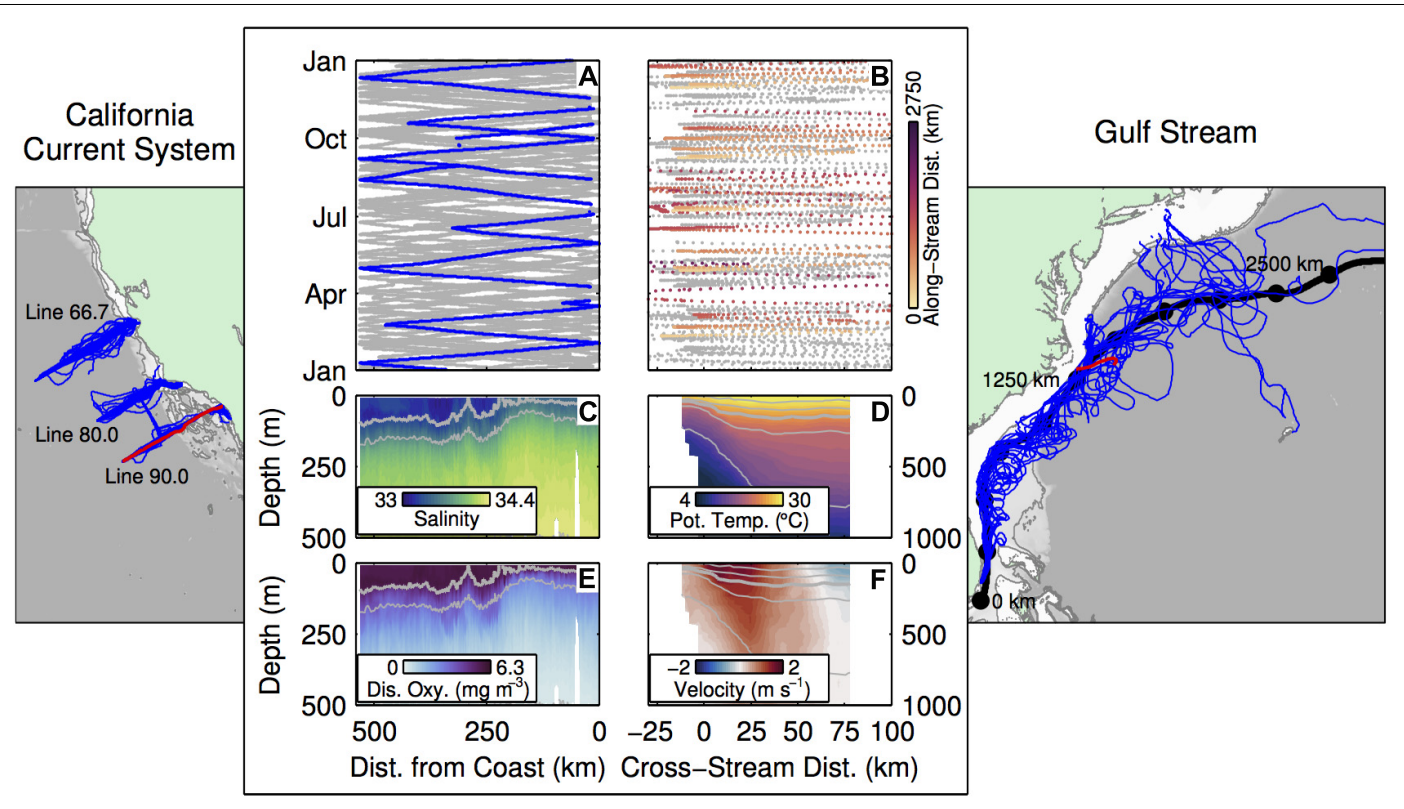

FIGURE 1 | Examples of multi-year, glider-based sampling in (left) an eastern boundary current system and (right) a western boundary current. Trajectories of all Spray gliders surveying the California Current System along CalCOFI lines 66.7, 80.0, and 90.0 (Rudnick et al., 2017 and references therein) and the Gulf Stream along the U.S. East Coast (Todd, 2017; Todd and Locke-Wynn, 2017; Todd et al., 2018a) are shown on the background map. (A,B) Glider sampling as a function of month and cross-shore or cross-stream distance with sampling in all years in gray and calendar year 2017 in color; Gulf Stream sampling in 2017 is colored by along-stream distance from $25^{\circ} \mathrm{N}$ following the mean 40-cm SSH contour (black trajectory on map with dots every $\left.250 \mathrm{~km}\right)$. (C-F) Example transects of salinity and dissolved oxygen along CalCOFI line 90.0 off Southern California in May 2017 and of potential temperature and velocity toward $50^{\circ}$ across the Gulf Stream near Cape Hatteras in August 2017 (red transects on map).

Though the Argo network was not designed to capture the details of boundary currents and lacks the resolution necessary to resolve narrow boundary currents, Argo data have nevertheless been used extensively in both WBCs and EBCs (see Table 2). Argo complements other boundary current observing efforts by providing collocated temperature and salinity measurements that are used to infer geostrophic shear from XBT temperature profiles, extending geostrophic shear from XBT and ocean glider data to 2,000 $\mathrm{m}$, measuring reference velocities at parking depth (typically 1,000 m), and linking transport measurements of boundary currents to the ocean interior through basinwide integration (e.g., Zilberman et al., 2018). Following recommendations at OceanObs'09 (Roemmich et al., 2010), the Argo program is currently moving to double float density in WBC regions (Jayne et al., 2017). The Kuroshio (Figure 3A) and Gulf Stream have historically been among the more densely populated sectors in the Argo array, while other boundary current regions (e.g., the Peru-Chile system, Figure 3B) lack the desired coverage.

\section{Remote Sensing}

Among the many oceanic variables that are routinely measured from satellites (Table 1), SSH, SST, and ocean color have been most used to study boundary current systems. Satellite measurements typically have resolutions of $\mathrm{O}(1)-\mathrm{O}(10) \mathrm{km}$ along the satellite track, with repeated measurements on daily to 10-day timescales at a given location. Boundary currents often have strong signatures in both SSH and SST, so satellite-derived gradients in these properties can approximate the strength and/or position of these currents (e.g., Imawaki et al., 2001), including variability on longer timescales (e.g., Qiu and Chen, 2005; Qiu et al., 2014; Andres, 2016). Synergy between dynamic height derived from temperature and salinity profiles and SSH can be exploited to produce synthetic reconstructions of boundary currents (van Sebille et al., 2010; Beal and Elipot, 2016; Majumder and Schmid, 2018; Zilberman et al., 2018), although these reconstructions crucially depend on assumptions about the nonsteric (barotropic and mass) variability. Weaknesses of SSH for observing boundary currents include reduced measurement quality within $40 \mathrm{~km}$ of the coast due to large uncertainties in the wet-tropospheric correction, unfiltered tides, and a lack of sufficient temporal and spatial resolution to capture the full spectrum of near-surface current variability observed by drifters (Poulain and Niiler, 1989; Centurioni and Niiler, 2003; Fratantoni and Richardson, 2006; Centurioni et al., 2008, 2009; Maximenko et al., 2009). Products that combine SSH and drifter measurements have improved eddy kinetic energy and dynamic topography estimates (Maximenko et al., 2009; Lumpkin and Garzoli, 2011; Rio et al., 2014; Rio and Santoleri, 2018). Estimates of chlorophyll derived from satellite ocean color measurements provide information on biological productivity in boundary current systems worldwide (e.g., Messié and Chavez, 2015; Gómez-Letona et al., 2017). Because ocean color observations have higher resolution $(\mathrm{O}(1) \mathrm{km})$ than satellite altimetry measurements, they potentially provide insight into the rich fields of submesoscale instabilities that exist within 


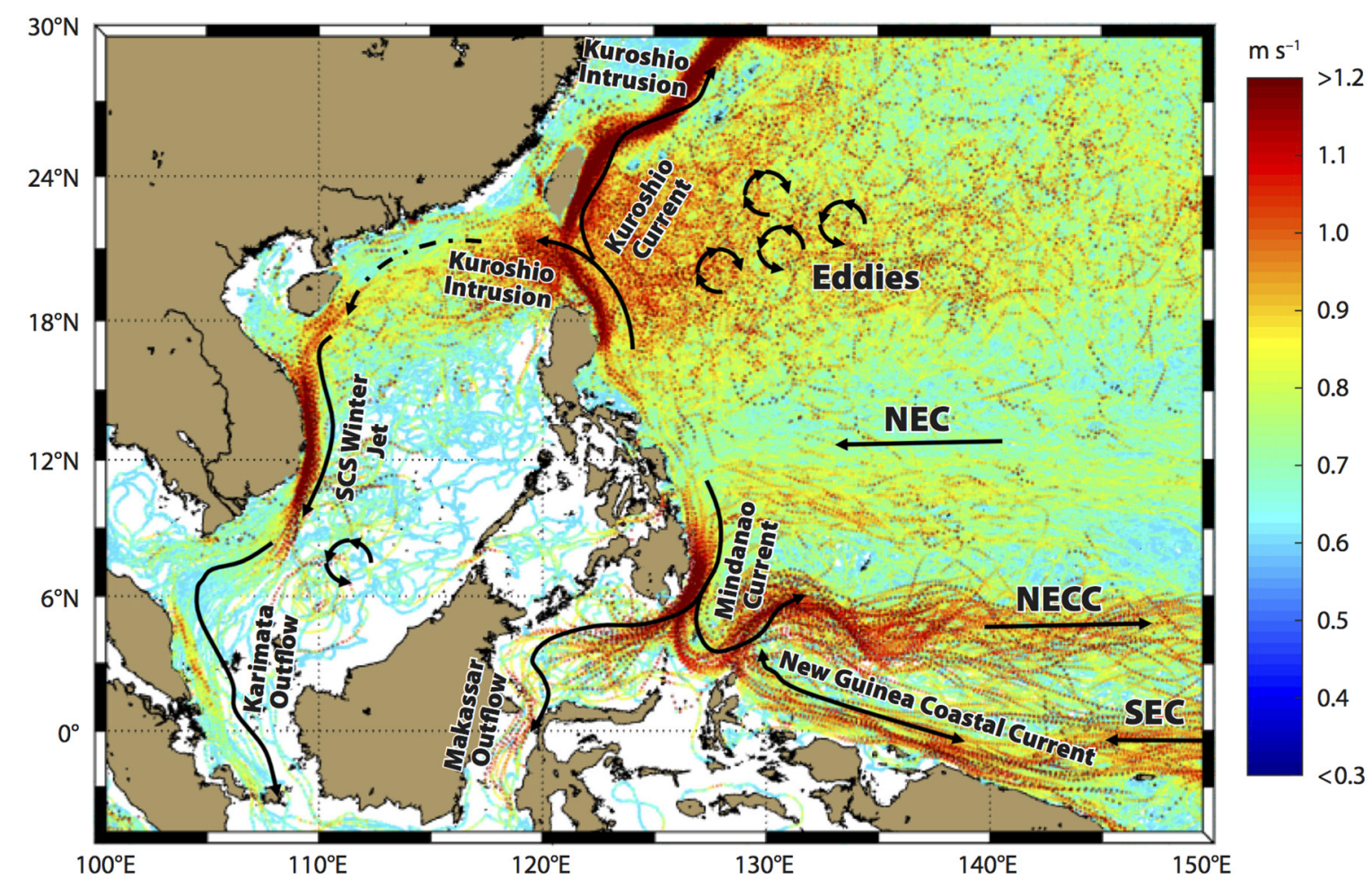

FIGURE 2 | Trajectories and near-surface velocity estimates from Global Drifter Program drifters in the western Pacific and marginal seas. Over 1.2 million discrete measurements from 1982 to 2014 are included. Paths of various boundary currents are clearly visible, as is the rich eddy field in the region of the Subtropical Countercurrent around $18-24^{\circ} \mathrm{N}$. NEC $=$ North Equatorial Current, NECC $=$ North Equatorial Counter Current, SEC $=$ South Equatorial Current, SCS $=$ South China Sea (Figure from Todd et al., 2018b).
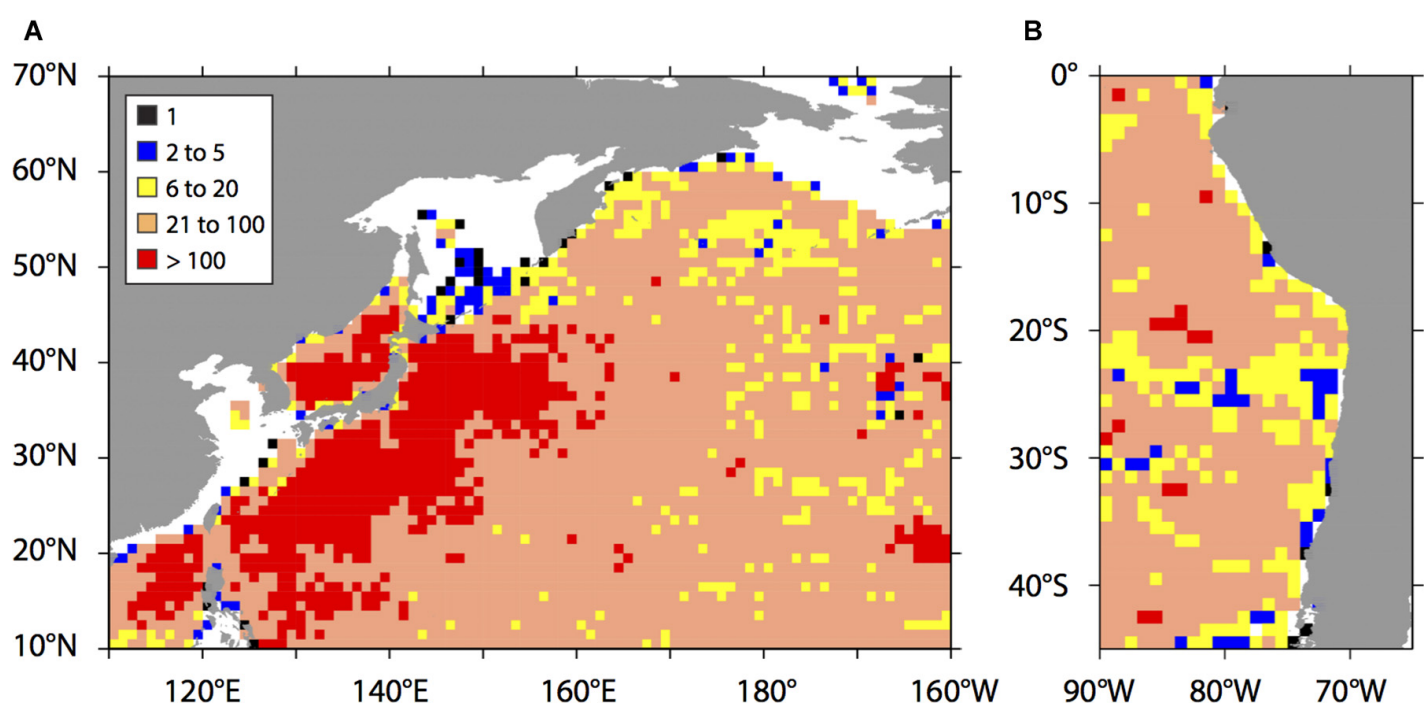

FIGURE 3 | Sampling density of Argo float (including Core Argo and BGC Argo) profiles per $1^{\circ}$ latitude $\times 1^{\circ}$ longitude bin, collected between January 2009 and September 2018, in the Kuroshio region (A), and the Peru-Chile Current region (B)

boundary current systems (Figure 4; Everett et al., 2014; Lee and Kim, 2018).

High-frequency (HF) radars (Paduan and Washburn, 2013) have been used effectively to monitor surface current variability of boundary currents (e.g., Kim et al., 2011; Archer et al., 2018). They directly map the total surface current within $\mathrm{O}(100) \mathrm{km}$ of the coast at high resolution in time $(\sim 1 \mathrm{~h})$ and space $(\sim 1 \mathrm{~km})$ during long-term deployments ( $\sim 10$ years). 


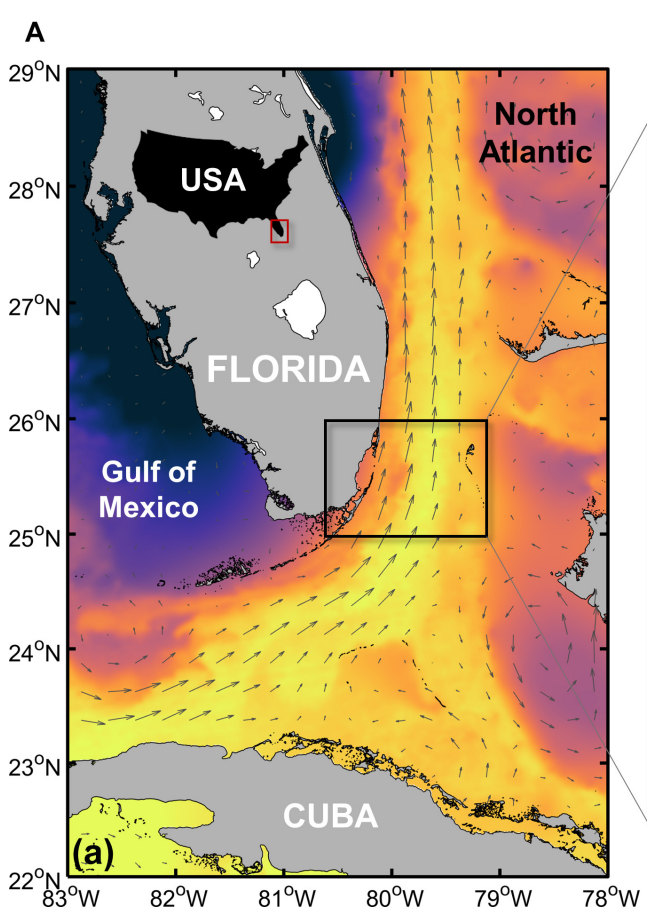

B

\section{FLORIDA CURRENT}

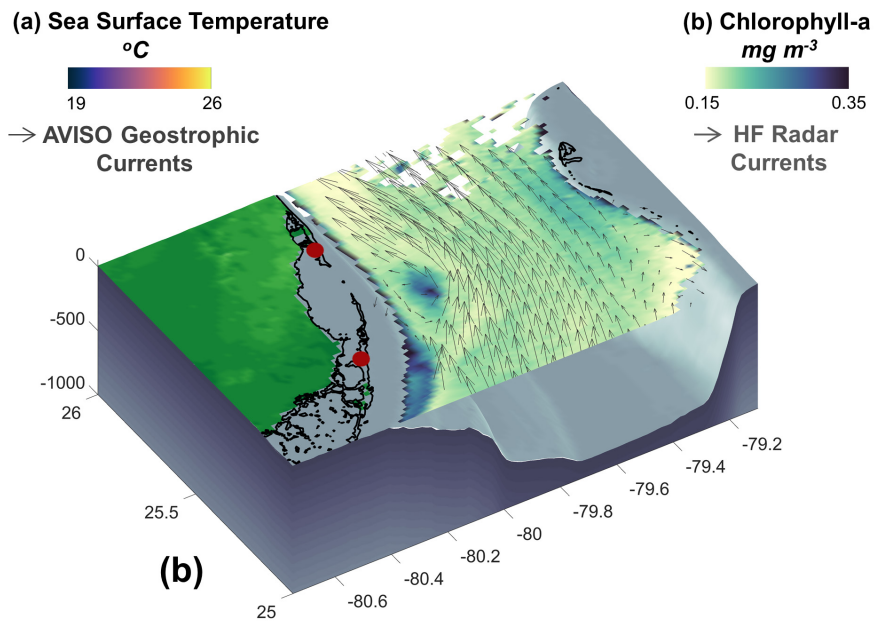

FIGURE 4 | Example of combined satellite- and land-based remote sensing of the Florida Current. (A) SST from GHRSST and surface geostrophic currents from AVISO. (B) Chlorophyll from MODIS AQUA and surface currents from HF radars (HF radar data from Archer et al., 2017b).

HF radar observations have proven useful for investigating both the mean surface velocity structure of boundary currents and associated submesoscale features that develop as boundary currents meander and shed eddies (Archer et al., 2018; Soh and Kim, 2018). Combining HF radar velocity estimates with satellitebased measurements of SST and ocean color (e.g., Figure 4) can provide a multidisciplinary view of surface circulation features at O(1)-km scales (e.g., Schaeffer et al., 2017). Some radar sites have been in continuous operation for more than a decade, offering opportunities to examine interannual to decadal variability of surface circulation. New radar sites can be installed and daisychained with existing sites, providing measurements of the alongshore evolution of boundary currents, as has been achieved along the West Coast of the United States (Kim et al., 2011).

\section{CURRENT STATUS OF REGIONAL BOUNDARY CURRENT OBSERVING SYSTEMS}

Existing observing systems for particular boundary currents are in various stages of development. Here, we review the current status of the observing systems currently operating in several EBCs and WBCs globally. The California Current System (see the section California Current System) is arguably the most well sampled boundary current in the world, offering hope that a fully integrated physical and biogeochemical system is achievable. Other boundary current systems, particularly in the Southern Hemisphere, are much less sampled. As was the case a decade ago
(Send et al., 2010), biogeochemical and ecosystem EOVs (Table 1) remain much less well sampled than physical EOVs. Table 2 provides a more comprehensive collection of recent scientific results for each boundary current system as well as sources of publicly available observations.

\section{Eastern Boundary Current Systems California Current System}

The California Current System is the EBC system of the subtropical North Pacific (Checkley and Barth, 2009). The equatorward flowing California Current carries relatively cool and fresh waters of subpolar origin, while the poleward California Undercurrent (Gay and Chereskin, 2009; Todd et al., 2011b) transports warmer saltier waters from the tropics along the continental margin. The California Current System is strongly influenced by the predominantly upwelling-favorable winds along the West Coast of North America.

Owing to the need to understand the collapse of the regional sardine fishery in the 1940s, there is a well-developed multidisciplinary observing system in the California Current System with a decades-long history of routine observations by the CalCOFI program (McClatchie, 2014, and references therein). Since 1949, CalCOFI has made regular (currently quarterly) measurements of physical, biological, and chemical properties at fixed stations along survey lines oriented perpendicular to the coast from research vessels (Figure 5). The establishment of the California Current Ecosystem Long Term Ecological Research program in 2004 brought further ship-based surveys and longterm moorings (Figure 5) focused on non-linear transitions in 


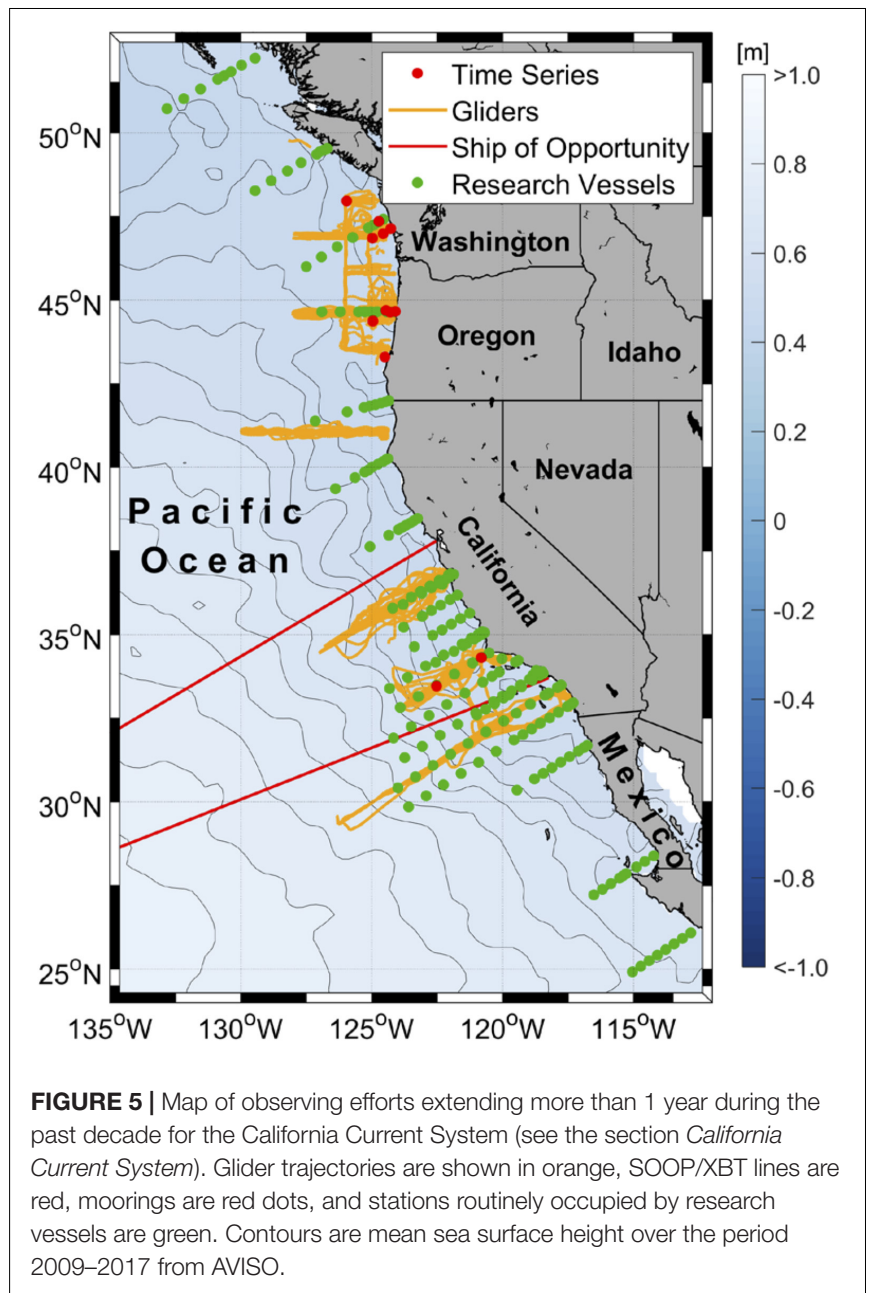

the pelagic ecosystem in response to ENSO, the Pacific Decadal Oscillation, and secular trends. In the Northern California Current, the Newport Hydrographic Line $\left(44^{\circ} 39.1^{\prime} \mathrm{N}\right)$ has been continuously occupied since 1961 (Huyer et al., 2007). Since 2005, autonomous underwater gliders have continuously surveyed along three of the CalCOFI lines as part of the CUGN (see the section Autonomous Underwater Gliders; Figures 1, 5) as well as along cross-shore transects as far north as the Washington Coast (Figure 5), returning measurements of physical properties and some biological proxies; the gliders complement the ship-based surveys by providing observations at higher spatial and temporal resolutions (e.g., Rudnick et al., 2017), albeit of a more limited set of properties. An array of PIES with end-point moorings off of Southern California monitors full-depth geostrophic transport; gliders routinely retrieve data from the PIES and transmit them to shore (Send et al., 2013). Since 2007, NOAA has led largescale coastal surveys along the U.S. West Coast every 2-4 years to determine the spatial distributions of carbon, oxygen, nutrient, biological, and hydrographic parameters (Feely et al., 2008, 2018). Starting in 2010, moored platforms throughout the California Current System established high-frequency time series of physical and biogeochemical parameters (Nam et al., 2011;
Harris et al., 2013; Sutton et al., 2016). More recently, the OOI Endurance Array (Smith et al., 2018; Trowbridge et al., 2019) has been deployed in the northern California Current System (Figure 5); moorings on the shelf and continental slope provide high-resolution time series, while gliders provide high-spatialresolution observations between the mooring sites. A network of shore-based HF radars provides real-time surface currents within about $150 \mathrm{~km}$ of the coast along nearly the entire U.S. West Coast (Kim et al., 2011).

\section{Peru-Chile Current System}

The Peru-Chile Current System (or Humboldt Current System) is the EBC system of the subtropical South Pacific, extending from the equator to southern Chile $\left(\sim 45^{\circ} \mathrm{S}\right)$. It is characterized by a persistent stratus cloud deck, equatorward surface currents, strong wind-driven coastal upwelling, poleward undercurrents, and filaments and eddies that develop along the coasts of Peru and Chile (see Colas et al., 2012 and references therein). A subsurface oxygen minimum zone (e.g., Paulmier and RuizPino, 2009) results in upwelled waters being nutrient rich but low in oxygen (e.g., Silva et al., 2009; Pizarro et al., 2016). Due to its proximity to the equator, the Peru-Chile Current System is strongly influenced by equatorial variability through propagation of Kelvin and coastal trapped waves (Dewitte et al., 2012; Mosquera-Vásquez et al., 2013) and anomalous advection during strong El Niños (e.g., Colas et al., 2008).

The dramatic impacts of El Niño events on both weather and fisheries have driven monitoring of oceanographic properties and fish stock assessments along the Peruvian coast since the 1960s (Figure 6; Grados et al., 2018). Over the past decade, these surveys have taken place monthly along the northern Peruvian coast and at least twice per year along the entire Peruvian coast; shipboard ADCP surveys are conducted at least seasonally. Biweekly time series along the $100-\mathrm{m}$ isobath between Paita $\left(5^{\circ} \mathrm{S}\right)$ and Ilo $\left(17^{\circ} \mathrm{S}\right)$, coastal tide-gauge stations, daily SST measurements at coastal laboratories, and a nearshore thermistor chain and bottom-mounted ADCP at $4^{\circ} 30^{\prime}$ S (Figure 6) allow monitoring of temperature and sea level anomalies and associated fluctuations in thermocline, oxycline, and nutricline depths. Measurements from the TAO/TRITON moored array and the Argo program (Figure 3B) provide key broad-scale context to these coastal observations. Efforts are underway to improve monitoring of the Peru-Chile Current System. For instance, sustained glider surveys across the frontal region off northern Peru, where El Niño impacts are large, are planned to begin by 2020 .

\section{Leeuwin Current System and South Australian Current System}

The boundary currents along the western and southern coasts of Australia have some unique features. The Leeuwin Current, which is the subtropical EBC of the southeastern Indian Ocean, is unusual in that it flows poleward along an eastern boundary, transporting warm, fresh tropical waters southward due to forcing by the Indonesian Throughflow and ocean atmosphere interactions in the Indian Ocean (Godfrey and Weaver, 1991); it is important for the upper ocean heat balance in the southeast 


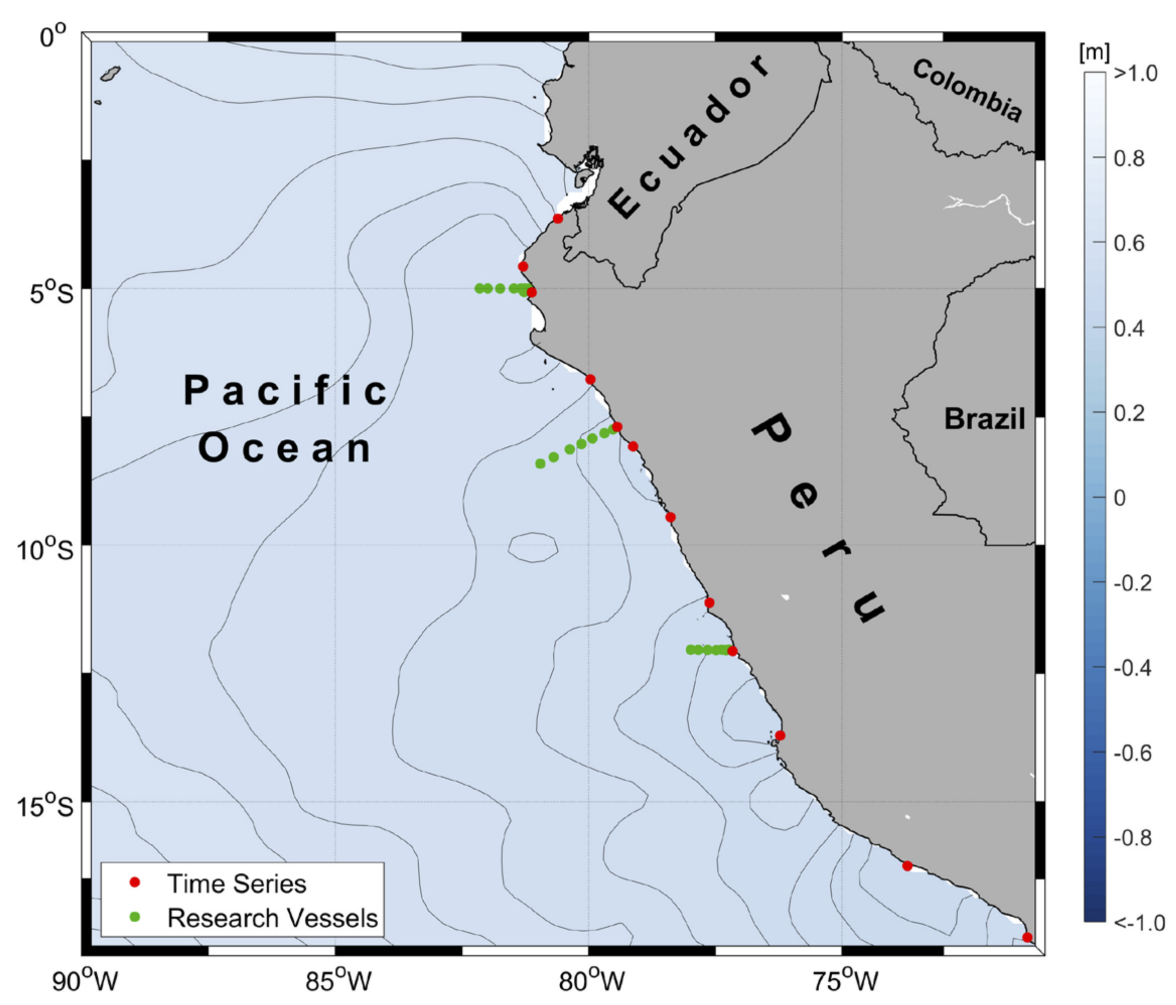

FIGURE 6 | Map of the boundary current observing effort for the Peru-Chile Current System (see the section Peru-Chile Current System) with details as in Figure $\mathbf{5}$.

Indian Ocean (Domingues et al., 2006). The Leeuwin Current hosts broad-scale downwelling (Furue et al., 2017; Liang et al., 2017) where eastward surface currents merge with the Leeuwin Current and then downwell into the Leeuwin Undercurrent at depths of 200-1,000 m. The equatorward Leeuwin Undercurrent carries waters of subantarctic origin along the western Australian coast (Woo and Pattiaratchi, 2008), leaving the coast near $22^{\circ} \mathrm{S}$ to contribute to the lower limb of a zonal overturning (Furue et al., 2017) and the subtropical gyre (Schott et al., 2009). In winter, the Leeuwin Current merges with the southwestward-flowing Holloway Current off the northwest coast of Australia, the eastward-flowing South Australian Current off the south coast, and the southward-flowing Zeehan Current off the west coast of Tasmania to form the longest shelfbreak boundary current system in the world (Ridgway and Condie, 2004; D'Adamo et al., 2009; Ridgway and Godfrey, 2015). Along the continental slope south of Australia, the westward flowing Flinders Current results from the collision of the equatorward deep ocean Sverdrup transport with the deep shelf slope of the Great Australian Bight (Middleton and Cirano, 2002; Middleton and Bye, 2007) and is a unique northern boundary current.

Coastal sea level observations at Fremantle have long been used as a proxy for the strength of the Leeuwin Current (Feng et al., 2003). Since 2008, the Australian Integrated Marine Observing System (IMOS; Hill et al., 2010) has been monitoring the shelf component of the Leeuwin Current near $32^{\circ} \mathrm{S}$ using shelf moorings (Feng et al., 2013), gliders, and HF radars (Figure 7). Short-term deployments (2012-2014) have also been carried out off the northwest coast of Australia (Ridgway and Godfrey, 2015). XBT surveys from ships of opportunity in and out of Fremantle, though not targeted for the Leeuwin Current, have taken place since the mid-1980s (Wijffels et al., 2008). IMOS makes ongoing observations of the South Australian Current system with dedicated moorings and glider missions monitoring the Flinders Current (Figure 7).

\section{Benguela Current System}

The Benguela Current Large Marine Ecosystem is the eastern boundary upwelling system of the South Atlantic. The equatorward Benguela Current is unique in that it is bounded by warm currents at its northern and southern edges, the Angola Current to the north and the Agulhas Current (see the section Agulhas Current) to the south. Coastal upwelling is linked to the seasonal position of the South Atlantic high pressure system, resulting in a number of upwelling cells along the southern African coast with divergent seasonality; the strongest year-round upwelling occurs off Lüderitz $\left(\sim 26^{\circ} S\right)$, effectively dividing the Benguela Current System into northern and southern subsystems. The northern Benguela upwelling system is highly productive (e.g., Louw et al., 2016) but also prone to hypoxia over the continental shelf that is modulated by a seasonal poleward undercurrent bringing low-oxygen waters to the shelf in summer and fall and an equatorward undercurrent that brings oxygenated water in winter and spring (Duncombe Rae, 2005; Mohrholz et al., 2008; Monteiro et al., 2008). The southern Benguela upwelling system experiences 


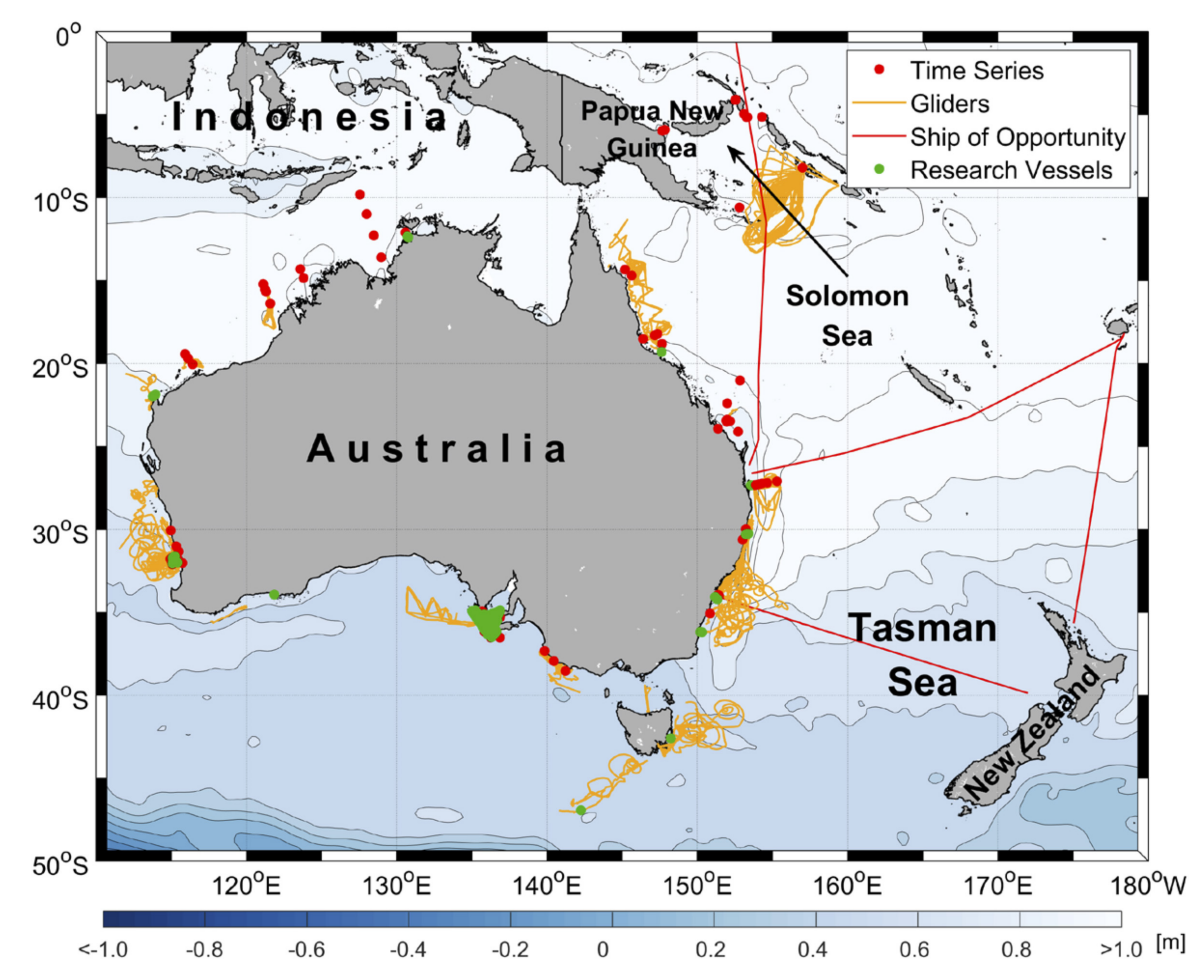

FIGURE 7 | Map of the boundary current observing efforts for the Leeuwin and South Australian Current Systems (see the section Leeuwin Current System and South Australian Current System) and the Southwestern Pacific (see the section Southwestern Pacific) with details as in Figure $\mathbf{5}$.

intense, pulsed upwelling in summer and quiescence in winter (Shannon and Nelson, 1996; Weeks et al., 2006; Hutchings et al., 2009c), although the direction of net Ekman transport appears to be offshore year-round (Carr and Kearns, 2003). This region also experiences hypoxia (and occasionally anoxia) in inshore waters, particularly in the region of St. Helena Bay (Pitcher and Probyn, 2011; Pitcher et al., 2014), but low-oxygen events are driven solely by bacterial respiration of organic matter from surface waters (Monteiro and van der Plas, 2006) and can result in mass mortalities of commercial fish stocks and rock lobster (e.g., Cockcroft et al., 2000, 2008; Van der Lingen et al., 2006).

In the southern Benguela Current System, monthly ship-based sampling of fisheries-relevant parameters took place through the 1950s and 1960s and then intermittently until 1988, after which surveys of fisheries, hydrographic, and chemical properties have been conducted two to three times per year (Figure 8; Moloney et al., 2004). Since 2012, quarterly surveys as part of the Integrated Ecosystem Program have additionally monitored the carbonate system. Various multifunctional moorings have been deployed over the years, including a buoy for oxygen and temperature and a harmful algal bloom detection system in the vicinity of St. Helena Bay (see Hutchings et al., 2009b). The Namibian Ministry of Fisheries and Marine Resources conducts regular monitoring of hydrographic conditions and commercial fish resources in Namibian waters of the northern Benguela (Figure 8); regular shipboard oceanographic monitoring began in 1999 with sampling frequency varying from two to eight occupations annually along most lines and up to twice per month off Lüderitz during the lobster fishing season. Long-term, though intermittent, moored observations have been collected at $23^{\circ} \mathrm{S}$, $14^{\prime} 03^{\circ} \mathrm{E}$, and coastal stations are maintained along the Namibian coast (Figure 8).

\section{Canary Current System}

The Canary Current Large Marine Ecosystem extends from the northern tip of the Iberian Peninsula $\left(43^{\circ} \mathrm{N}\right)$ to south of Senegal $\left(12^{\circ} \mathrm{N}\right)$, corresponding to the extent of the northeasterly trade winds in the northeastern Atlantic. Upwelling occurs yearround with meridional shifts in the trade winds leading to seasonality in the latitudinal range of upwelling, particularly in the south (Benazzouz et al., 2014; Faye et al., 2015), where strong intraseasonal to longer timescale variability is driven by internal or remotely forced pulsations of the trade winds, passages of African easterly waves, and oceanic coastally trapped waves (Polo et al., 2008; Diakhaté et al., 2016; Oettli et al., 2016). The ecosystem is broadly divided by the Strait of Gibraltar into the Iberian and the Northwest African areas, though strong subregional differences are observed due to variability in factors including coastal configuration, oxygen concentration, nutrient fertilization, and productivity (Arístegui et al., 2009). The continental shelf in the Canary Current System is the most extensive of any EBC, and persistent circulation features are associated with the topography of the shelf. Large filaments of coastal upwelled water stretch offshore from the numerous capes and promontories (e.g., Cape Guir and Cape Blanc), transporting waters rich in organic matter into the oligotrophic 


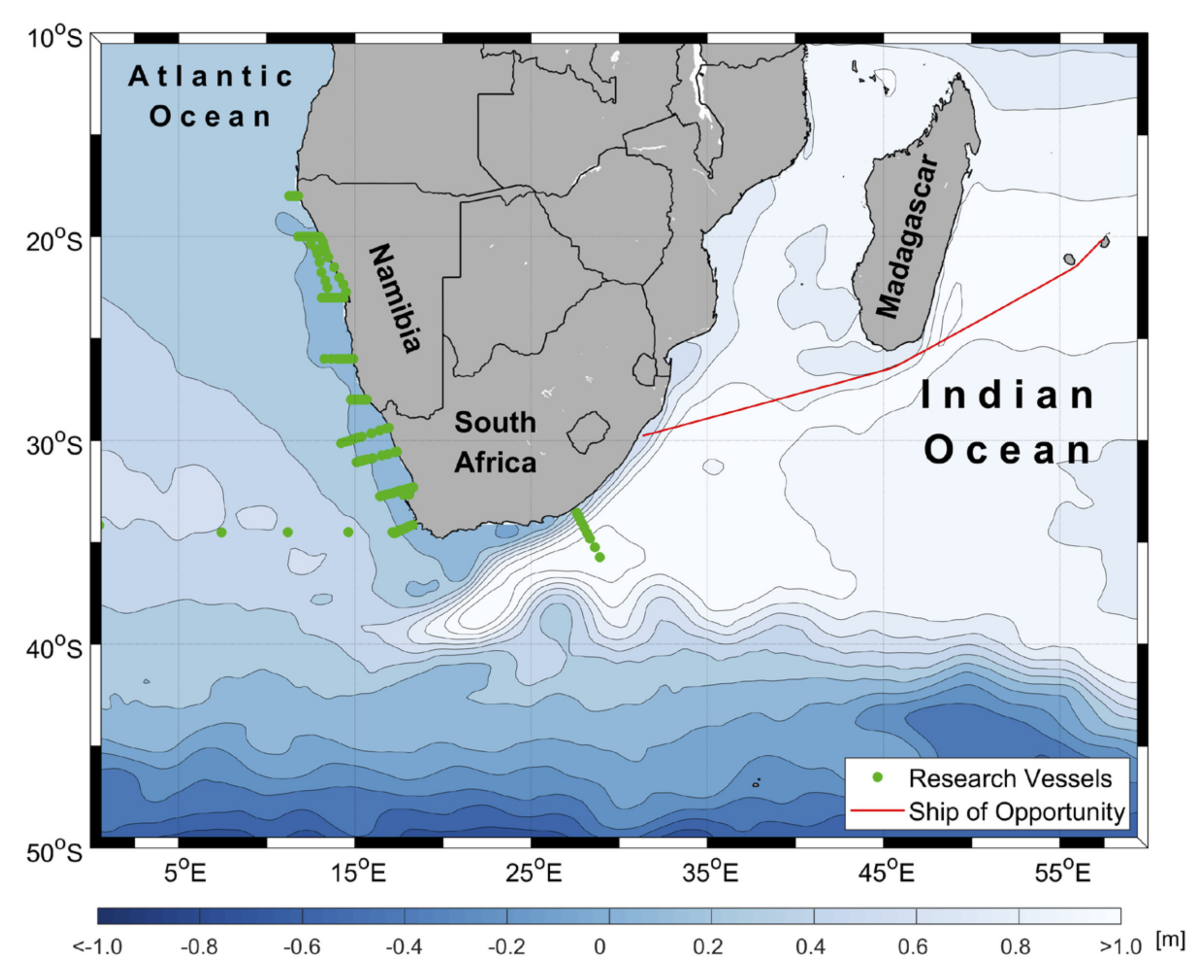

FIGURE 8 | Map of the boundary current observing effort for the Bengula Current System (see the section Benguela Current System) and the Agulhas Current (see the section Agulhas Current) with details as in Figure $\mathbf{5}$.

subtropical gyre (Álvarez-Salgado et al., 2007; Lovechio et al., 2018). The Canary Archipelago interrupts the equatorward flow of the Canary Current, leading to strong mesoscale variability downstream of the islands (Arístegui et al., 1994). Island eddies and upwelling filaments interact to exchange water properties, resulting in an efficient route for transporting organic matter to the open ocean (Arístegui et al., 1997; Barton et al., 1998). As a major upwelling area, the Canary Current System is highly productive and the focus of intensive fisheries. Interannual and decadal variability in fisheries landings and distributions of small pelagic fishes has been related to environmental changes associated with the North Atlantic Oscillation and, to a lesser extent, ENSO in the southern part of the region (see reviews in Arístegui et al., 2006; Arístegui et al., 2009).

There have been numerous process-oriented field programs in Canary Current System in the past 20 years, including the Coastal Transition Zone (CTZ; Barton and Arístegui, 2004) and Canary Islands Azores Gibraltar Observations (CANIGO; Parrilla et al., 2002) programs. However, physical, biogeochemical, and ecosystem monitoring efforts have been less routine than have other EBCs (Figure 9). The European Station for Time series in the Ocean Canary Islands (ESTOC) has completed over 20 years of continuous meteorological and surface and mid-water physical and biogeochemical monitoring. The Cape Verde Ocean and Atmospheric Observatories (CVOO/CVAO) are a deep water mooring and an atmospheric station that have been deployed since 2006 in a region critical for climate and greenhouse gas studies and for investigating dust impacts on marine ecosystems.
Both ESTOC and CVOO/CVAO are part of the European open ocean fixed point observatories (FixO3). An additional mooring has been recording oceanographic properties and particle fluxes with sediment traps off Cape Blanc continuously since 2003 (Nowald et al., 2015). Long-term measurements of coastal oceanic and atmospheric properties from buoys off Morocco and Senegal have begun during the last 4 years. Ship-based hydrographic and biogeochemical sampling has taken place twice per year since 2006 at the latitude of the Canary Archipelago as part of the RAPROCAN program (Figure 9), which aims to monitor the Canary Current and maintain the ESTOC mooring. Gliders have periodically surveyed between the African coast and the Cape Verde Islands (Figure 9; Karstensen et al., 2017; Kolodziejczyk et al., 2018).

\section{Western Boundary Current Systems Northwestern Atlantic}

The Gulf Stream comprises the upper limb of the AMOC in the North Atlantic subtropical gyre, carrying warm, saline waters from the tropics to higher latitudes. It flows along the eastern seaboard of the United States before separating from the continental margin near Cape Hatteras. The Labrador Current is the WBC of the subpolar gyre. The North Atlantic Deep Western Boundary Current is a deep limb of the AMOC that carries cold water masses from the tail of the Grand Banks of Newfoundland equatorward (Pickart and Watts, 1990). It encounters the Gulf Stream at the tail of the Grand Banks and again at Cape Hatteras, where a portion is entrained into the abyssal interior 


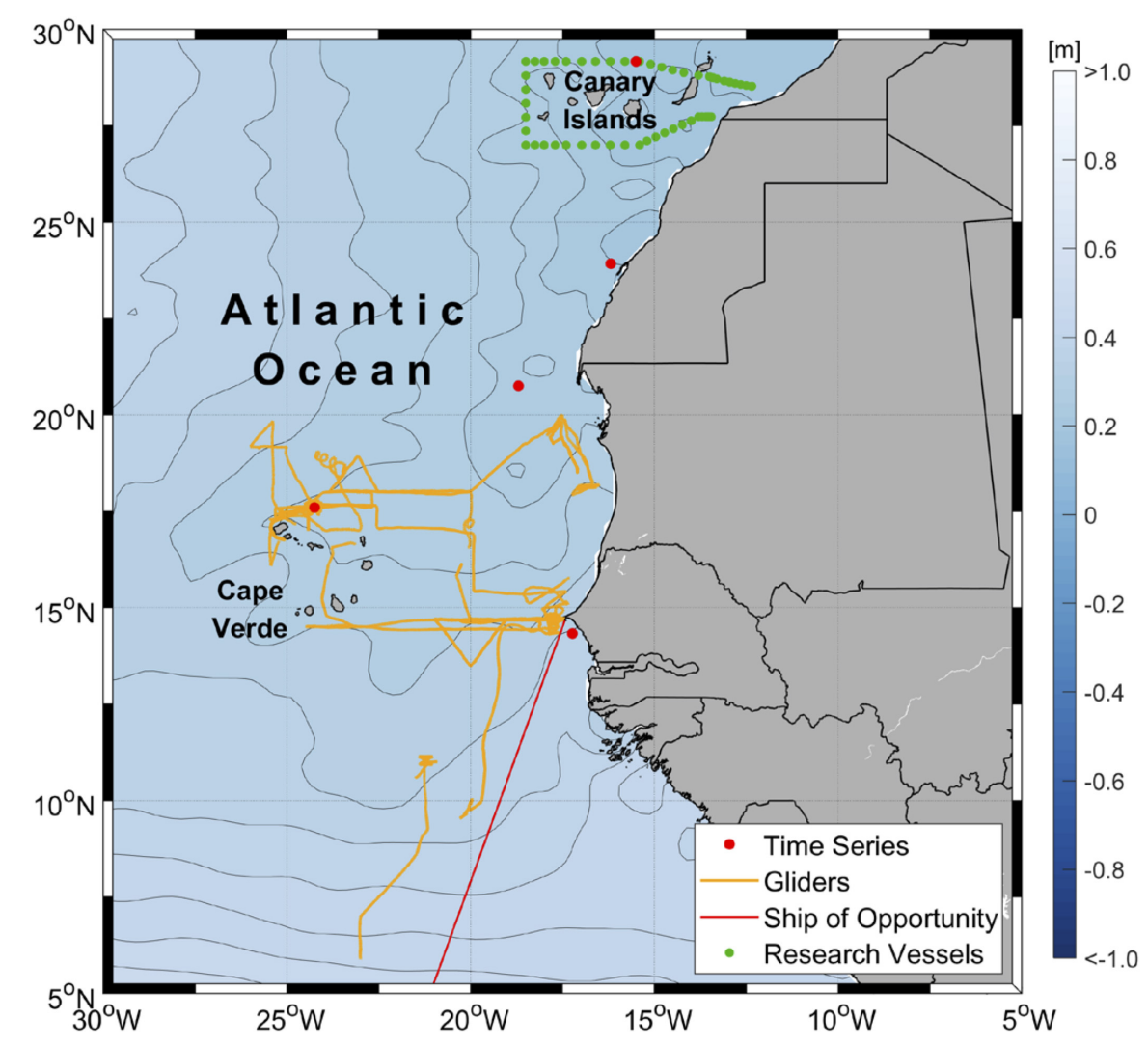

FIGURE 9 | Map of the boundary current observing effort for the Canary Current System (see the section Canary Current System) with details as in Figure 5.

(Pickart and Smethie, 1993; Bower and Hunt, 2000a,b) while the rest continues to flow equatorward along the western boundary and into the Southern Hemisphere (Southwestern Atlantic). The strength of the Deep Western Boundary Current may influence the latitude at which the Gulf Stream detaches from the continental margin (Thompson and Schmitz, 1989). Along the edge of the adjacent Middle Atlantic Bight shelf, a persistent shelfbreak front and associated shelfbreak jet (Linder and Gawarkiewicz, 1998) transport waters equatorward with secondary frontal circulation leading to upwelling and elevated primary productivity (Marra et al., 1990). The shelfbreak jet continues southward until just north of Cape Hatteras, where it turns offshore as it encounters the much stronger Gulf Stream (Gawarkiewicz and Linder, 2006).

The boundary current observing system for the subtropical northwest Atlantic (Figure 10) is anchored by decades-long measurements at several fixed locations along the boundary. In the Florida Strait near $27^{\circ} \mathrm{N}$, cable-based measurements of Gulf Stream transport and quarterly to bi-monthly ship-based sampling have been ongoing since 1982 as part of the Western Boundary Time Series (WBTS; Baringer and Larsen, 2001; Meinen et al., 2010). Far to the northeast, where the Gulf Stream has separated from the continental margin, XBT, shipboard ADCP, and surface temperature and salinity measurements are obtained twice weekly from $M / V$ Oleander, a cargo ship running between New Jersey and Bermuda (Rossby et al., 2010, 2014;
Wang et al., 2010). The AX10 XBT line between New York and Puerto Rico crosses the Gulf Stream just upstream of the Oleander line and conducts high-resolution sampling within the boundary current (e.g., Domingues et al., 2018). Since 2015, gliders have been used to routinely survey across the Gulf Stream between Florida and Massachusetts (Figure 1; Todd, 2017; Todd and Locke-Wynn, 2017; Todd et al., 2018b), providing subsurface observations that fill the gap between the WBTS and Oleander and AX10 lines. Two moored arrays with complementary repeat hydrographic sampling have focused on the Deep Western Boundary Current for a decade or more. The RAPID-MOCHA array of subsurface moorings and PIES near $26.5^{\circ} \mathrm{N}$ has been in place since 2004 with hydrographic stations reoccupied about every 9 months (Meinen et al., 2013). Farther north, the Line W array of subsurface moorings was in place from 2004 to 2014 with repeat ship-based sampling every 6-12 months (Toole et al., 2017). The OOI Pioneer Array south of New England (Smith et al., 2018; Trowbridge et al., 2019) and the PEACH array near Cape Hatteras use a mixture of moorings, gliders (e.g., Gawarkiewicz et al., 2018), and land-based remote sensing (e.g., Haines et al., 2017) to characterize the dynamics of the shelfbreak jet and exchange between the shelf and deep ocean in the vicinity of the Gulf Stream and its eddies. In the subpolar northwestern Atlantic at $53^{\circ} \mathrm{N}$, transport of the Labrador Current has been monitored since 1997 using a combination of moored and shipboard observations (Zantopp et al., 2017). 


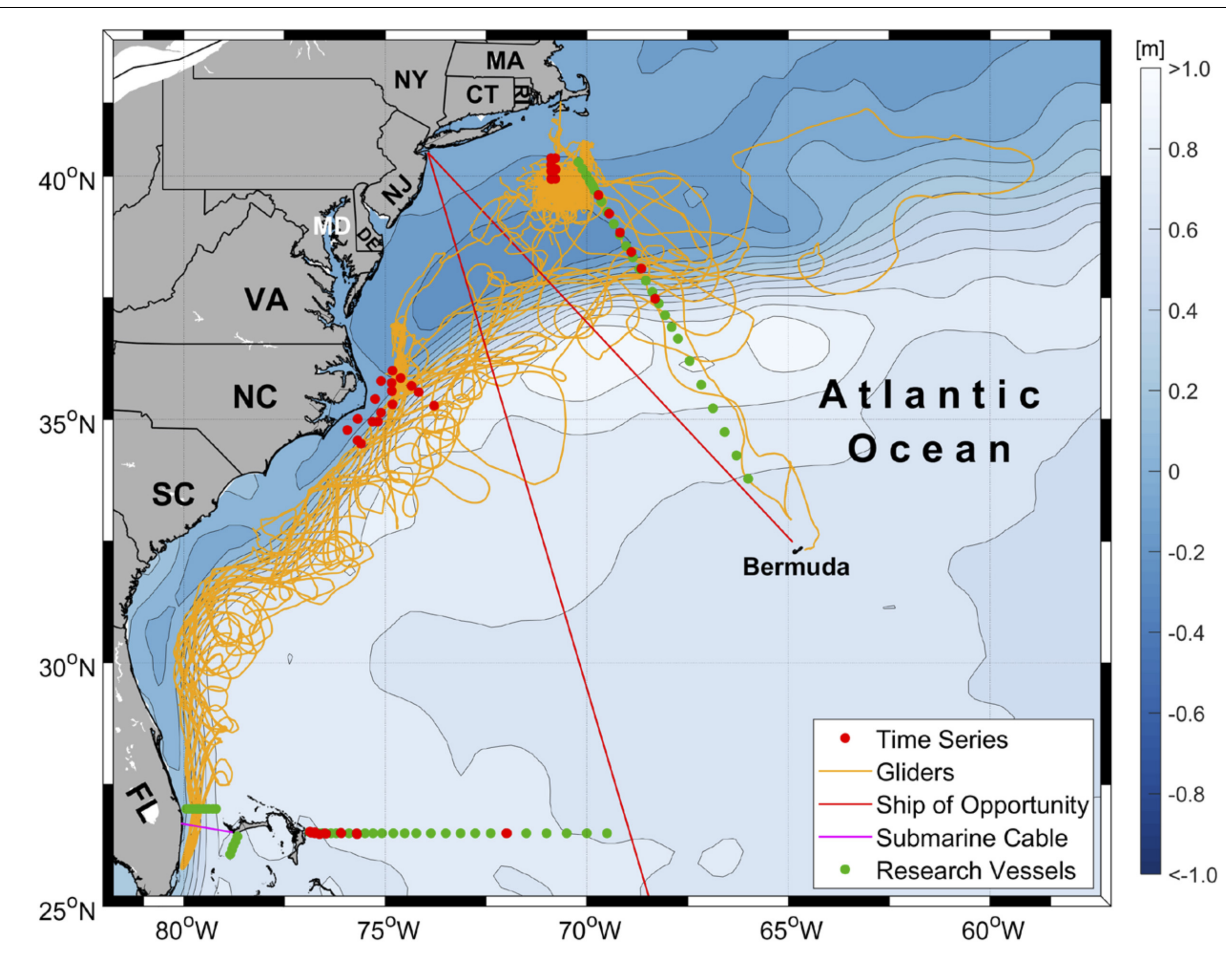

FIGURE 10 | Map of the boundary current observing efforts for the Northwestern Atlantic (see the section Northwestern Atlantic) with details as in Figure $\mathbf{5}$ and the addition of the submarine cable location in the Florida Strait.

\section{Northwestern Pacific}

In the Northwestern Pacific, bifurcation of the westward North Equatorial current between $11^{\circ}$ and $13^{\circ} \mathrm{N}$ along the Philippine coast (Qiu and Chen, 2010; Rudnick et al., 2015b) forms the poleward Kuroshio and the equatorward Mindanao Current. The Kuroshio becomes a more coherent jet as it flows along the Taiwanese coast (e.g., Centurioni et al., 2004), into the East China Sea, and along the southern Japanese coast before separating from the continental margin near $35^{\circ} \mathrm{N}$ to form the Kuroshio Extension, an eastward, meandering jet in the open North Pacific. The Mindanao carries waters from the North Pacific southward to feed tropical circulation in both the Pacific and Indian Oceans (Schönau et al., 2015). The Oyashio is the western boundary current of the North Pacific subpolar gyre and converges with the Kuroshio to the east of Japan. This convergence region has rich frontal structure as various water masses meet and are modified and is a key area for fisheries (Yasuda, 2003).

The Japan Meteorological Agency (JMA) has carried out repeat hydrographic surveys two to five times annually at the PN line in the East China Sea since 1971 (Aoyama et al., 2008; Figure 11) and at the TK line south of Kyushu since 1987 (Oka and Kawabe, 2003) to monitor physical and biogeochemical EOVs in the Kuroshio. JMA has also monitored the Ryukyu Current system (Ichikawa et al., 2004) flowing south of the Ryukyu Islands at the OK line southeast of Okinawa, which is connected to a zonal section along $24^{\circ} \mathrm{N}$. Furthermore, the JMA has maintained physical and biogeochemical surveys along $137^{\circ} \mathrm{E}$ across the western North Pacific to monitor major currents of the subtropical and tropical gyres including the Kuroshio (Nakano et al., 2015; Oka et al., 2018). Monthly fisheries surveys and hydrographic stations along the A-line off Hokkaido have been occupied since 1987 (Kuroda et al., 2015) with collocated long-term moorings (Kono and Kawasaki, 1997). JAMSTEC has sampled hydrographic stations $\mathrm{K} 2\left(47^{\circ} \mathrm{N}, 160^{\circ} \mathrm{E}\right)$ and KNOT $\left(44^{\circ} \mathrm{N}, 155^{\circ} \mathrm{E}\right)$ in the subpolar north Pacific at least annually since 1997 (Wakita et al., 2010). The Kuroshio Extension Observatory (KEO; Cronin et al., 2015) is a surface mooring that has been located in the subtropical recirculation gyre south of the Kuroshio Extension at $32.3^{\circ} \mathrm{N}, 144.6^{\circ} \mathrm{E}$ (Figure 11) since 2004. KEO monitors air-sea exchanges of heat, moisture, momentum, and $\mathrm{CO}_{2}$; sea surface temperature, salinity, and ocean acidification; and upper ocean temperature, salinity, and currents below the surface buoy. Since 2014, a sediment trap mooring has been located at KEO (Honda et al., 2018). More recently, the CLIVAR Northwestern Pacific Ocean Circulation and Climate Experiment (NPOCE) has deployed an array of subsurface moorings, some with real-time data transmission, across the western Pacific, South China Sea, and Indonesian seas (Figure 11) that cover the major currents in these regions (e.g., Hu et al., 2013, 2015, 2016; Zhang et al., 2014; Chen et al., 2015; Wang et al., 2017). Multiple XBT transects cross boundary currents within the region (see Goni et al., 2019). Gliders have been deployed for extended periods in the Kuroshio and Mindanao (Figure 11), generally sampling obliquely across the boundary currents as they were advected downstream (e.g., Rainville et al., 2013; Schönau and Rudnick, 2017). 


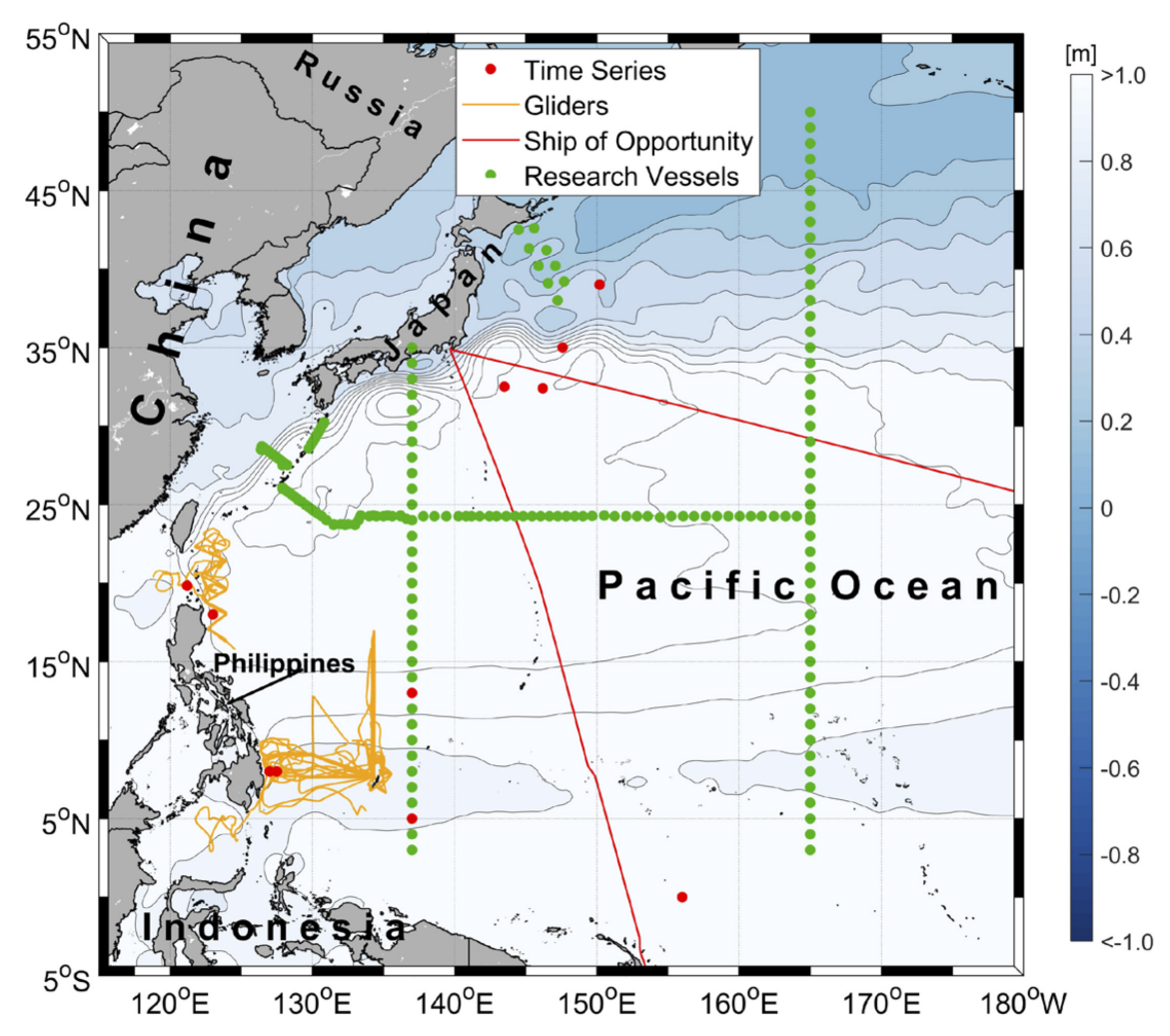

FIGURE 11 | Map of the boundary current observing effort for the Northwestern Pacific (see the section Northwestern Pacific) with details as in Figure $\mathbf{5}$.

\section{Southwestern Pacific}

The East Australian Current is the subtropical WBC of the South Pacific; it is a strong, meandering current with large poleward heat transport (Sloyan et al., 2016) that separates from the continental margin between $30^{\circ} \mathrm{S}$ and $32^{\circ} \mathrm{S}$ to join a dynamic eddy field (Cetina Heredia et al., 2014) in the Tasman Sea. The low-latitude WBC system of the South Pacific originates as the equatorward Gulf of Papua Current along the northeast coast of Australia, which then flows through the Solomon Sea as the New Guinea Coastal Undercurrent before feeding into the equatorial current system. This is a major contributor to the mass and heat budget of the tropical Pacific, acting as a conveyor belt for micronutrients from the western continental margins to the eastern Equatorial Pacific upwelling region. These low-latitude WBCs split into numerous branches around topographic obstacles and flow through narrow passages, presenting challenges for sustained observing.

The sustained observing system for the East Australian Current and its extension (Figure 7) currently consists of highdensity XBT transects (PX05, PX06, PX30, and PX34; Goni et al., 2019); Argo floats; a deep moored array at approximately $27^{\circ} \mathrm{S}$; HF radar sites near $32^{\circ} \mathrm{S}$ and $30^{\circ} \mathrm{S}$; a regional array of shelf moorings (including biogeochemical and biological sensors) at $30^{\circ} \mathrm{S}, 34^{\circ} \mathrm{S}$, and $36^{\circ} \mathrm{S}$; and numerous glider deployments from northern Australia $\left(11^{\circ} \mathrm{S}\right)$ to the Tasman Sea $\left(42^{\circ} \mathrm{S}\right)$ (Roughan and Morris, 2011; Roughan et al., 2013, 2015). These observational platforms complement each other well, providing a distributed boundary current observational system for the East Australian Current that has been shown to constrain ocean models well (Kerry et al., 2018). Additional sustained measurements are needed to characterize the seasonal changes in the transports of mass, heat, and freshwater in the East Australian Current and its eddy field. Effective monitoring strategies would be to deploy moored arrays in key regions; to increase Argo float and drifter density in the WBC region; and to implement glider sampling along existing high-density XBT lines within the East Australian Current, its eddy field, and recirculation.

In the low-latitude WBC system, long-term, sustained observations of the heat and mass transport through the southern entrance of the Solomon Sea have been provided by gliders since 2007 (Davis et al., 2012) and an array of PIES since 2012 (Figure 7). Concurrent, short-term process studies including mooring deployments have been conducted as part of the CLIVAR-SPICE program (Ganachaud et al., 2014). Future monitoring efforts should integrate measurements across platforms, with the existing measurements in the southern entrance complemented by observations at the northern exits of the Solomon Sea (e.g., moorings, HF radars, and glider transects) to resolve the partitioning of the flow joining the equator (see Smith et al., 2019).

\section{Agulhas Current}

The Agulhas Current is the poleward WBC of the subtropical South Indian Ocean (Lutjeharms, 2006). It flows as a fast 
$\left(>1.5 \mathrm{~m} \mathrm{~s}^{-1}\right)$, deep-reaching $(>3,000 \mathrm{~m})$ jet along the continental slope of southeast Africa (Beal and Bryden, 1999; Beal et al., 2015). Near $40^{\circ} \mathrm{S}$, the Agulhas flows into the open ocean, where it retroflects under the influence of the large-scale wind stress curl to flow eastward into the Indian Ocean as the Agulhas Return Current (de Ruijter et al., 1999). Leakage of warm, salty Agulhas waters into the South Atlantic by rings, eddies, and filaments (Boebel et al., 2003; Richardson, 2007) is thought to influence the AMOC on timescales from decades to millennia (Beal et al., 2011).

In 2010, the Agulhas Current Time-series experiment (ACT) established a moored array to measure the volume transport of the Agulhas Current along a satellite altimeter ground-track (\#96) near $34^{\circ} \mathrm{S}$ (Figure 8) for a period of 3 years. The array consisted of seven full-depth current meter moorings and four CPIES that captured the breadth and depth of the Agulhas jet, including during offshore meander events (Beal et al., 2015). Following ACT, a consortium of South African, U.S., and Dutch scientists deployed the Agulhas System Climate Array (ASCA) in 2016 for long-term monitoring of the Agulhas Current as part of GOOS. ASCA augmented the original ACT array design with conductivity-temperature recorders to measure the heat and freshwater fluxes. The long-term success of ASCA was dependent on an ambitious plan of capacity building and resource sharing among nations, and, owing to a number of challenges, this plan was not fulfilled, and the array was pulled out of the water in 2018, following a 2-year deployment. In 2015, the Shelf Agulhas Glider Experiment (SAGE) demonstrated the feasibility of operating autonomous robotic platforms to sample the shelf regions of the Agulhas Current (Krug et al., 2017). Since SAGE, growing regional interest in monitoring with autonomous platforms led to formation of a South African multi-institutional scientific consortium named Gliders in the Agulhas (GINA). GINA conducted two additional glider missions in 2017 and 2018 and is working toward the development of a sustained glider observing system for the Agulhas Current coastal and shelf regions. The influence of the Agulhas leakage on the AMOC has been monitored since 2013 by an array of CPIES and tall moorings as part of the SAMBA line at $34.5^{\circ} \mathrm{S}$ (Figure 8; Ansorge et al., 2014). Thus far, no sustained ecological or biogeochemical measurements have been made in the Agulhas, though the addition of oxygen sensors to SAMBA moorings is planned.

\section{Southwestern Atlantic}

In the South Atlantic, the WBC system consists of the poleward Brazil Current and the equatorward North Brazil Undercurrent, both of which originate from the bifurcation of the South Equatorial Current between $10^{\circ} \mathrm{S}$ and $20^{\circ} \mathrm{S}$ (e.g., da Silveira et al., 1994; Rodrigues et al., 2007), and the equatorward Malvinas current in the subpolar gyre. The Brazil Current and Malvinas Current both separate from the South American continental margin between $35^{\circ} \mathrm{S}$ and $40^{\circ} \mathrm{S}$ to flow eastward at the BrazilMalvinas confluence (Olson et al., 1988). The North Brazil Undercurrent constitutes a bottleneck for the interhemispheric mean flow of the upper limb of the AMOC as it transports warm waters of South Atlantic origin across the equator (e.g., Schott et al., 1998; Zhang et al., 2011; Rühs et al., 2015). The Deep
Western Boundary Current carries much of the lower limb of the AMOC off the coast of South America (Schott et al., 2005; Meinen et al., 2013).

For more than a decade, high-density XBT transects (Goni et al., 2019) have been occupied near $22^{\circ} \mathrm{S}$ and $34^{\circ} \mathrm{S}$ (AX97 and AX18) across South Atlantic WBCs (Figure 12; Dong et al., 2015; Lima et al., 2016). Near $11^{\circ} \mathrm{S}$, an array of four tall moorings and two PIES has measured transport of the North Brazil Current since 2013 (Figure 12; Hummels et al., 2015). At $34.5^{\circ} \mathrm{S}$ (Figure 12), an array of PIES, CPIES, and a bottom-mounted ADCP has monitored the Brazil Current and Deep Western Boundary Current (Meinen et al., 2013, 2017, 2018) in conjunction with periodic hydrographic surveys (Valla et al., 2018). A series of yearlong deployments of current meter arrays along $41^{\circ} \mathrm{S}$ since 1993 (Figure 12; Vivier and Provost, 1999; Spadone and Provost, 2009; Paniagua et al., 2018), in conjunction with satellite altimetry, has allowed for production of a 24-year transport time series for the Malvinas Current (Artana et al., 2018a).

\section{FUTURE OUTLOOK}

We recommend establishing and maintaining a global network of boundary current observing systems. Each distinct observing system will need to be tailored to the unique aspects of that particular boundary current system and also follow best practices established by the international community. Such a network of regional boundary current observing systems is a crucial element of GOOS. To date, boundary current observing systems in different regions and countries have developed largely independently. Development and maintenance of a global network of boundary current observing systems that is fit for purpose would benefit from the standards outlined in the Framework for Ocean Observing (Lindstrom et al., 2012). In particular, application of the Framework across boundary current observing systems should foster communication and data sharing; contribute to capacity building, particularly in developing countries; encourage confidence and support from funding agencies; and promote international collaboration and scientific and technological innovation.

Boundary currents typically lie within the EEZs of coastal states, so development and maintenance of boundary current observing systems will require the cooperation and support of appropriate governing authorities. Considering the difficulty of obtaining international funding for observations in national waters, there is a need for a community of regional boundary observers. Moreover, many boundary currents span multiple countries, so the observing system for a single boundary current system is likely to require collaboration and coordination between several countries. The advective nature of boundary currents may even require that mobile or drifting assets deployed within one country's EEZ be recovered within another EEZ. Sharing of measurements taken within EEZs, particularly those that have economic impacts such as some biogeochemical measurements, remains a challenge. By moving toward international collaboration in the design and implementation 


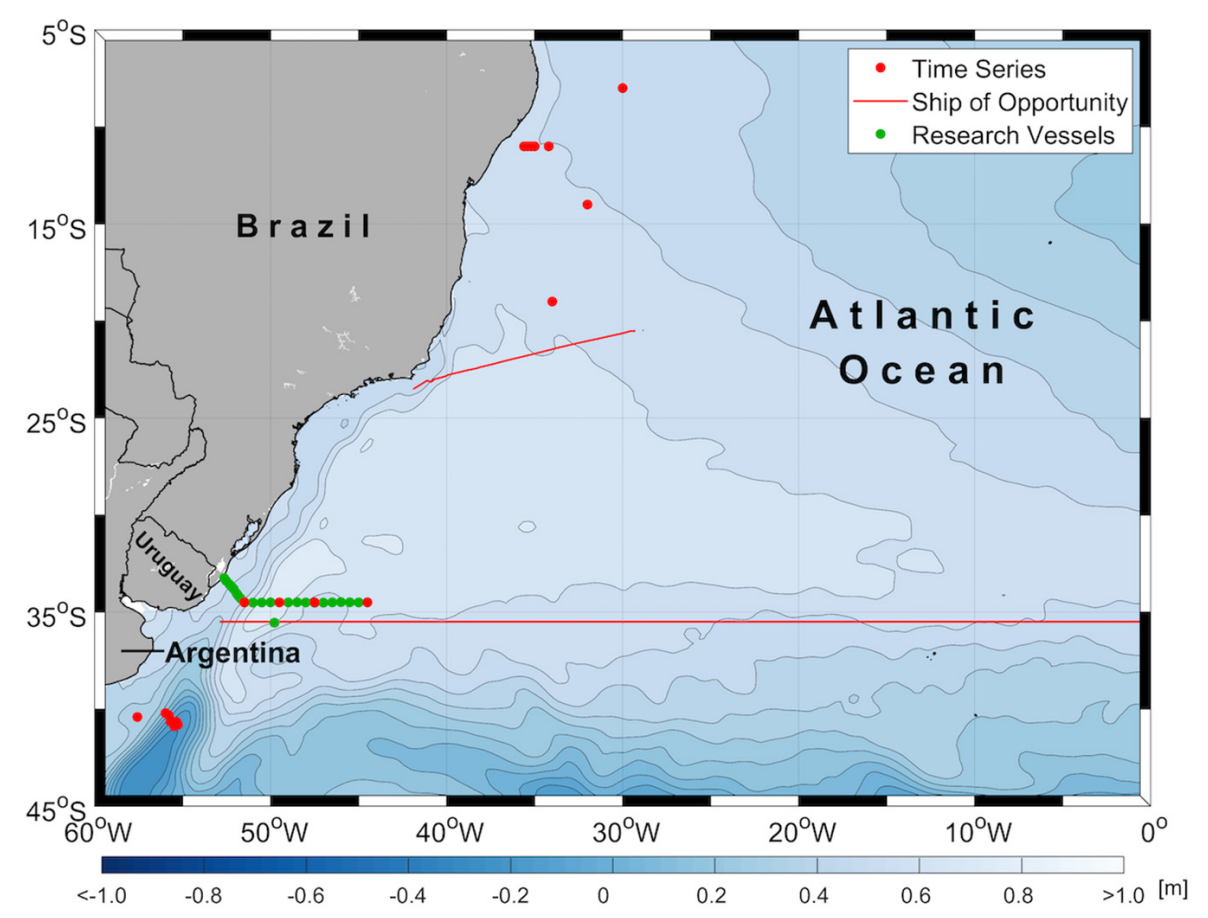

FIGURE 12 | Map of the boundary current observing system for the Southwestern Atlantic (see the section Southwestern Atlantic) with details as in Figure $\mathbf{5}$.

of boundary current systems as suggested by the Framework for Ocean Observing, there is hope for building the high-level governance structure needed to surmount the challenges posed by boundary currents falling within EEZs. The Large Marine Ecosystems effort has identified distinct boundary regions that cross international borders and has gained international traction through the Global Environment Facility and the International Union for Conservation of Nature; leveraging this effort to facilitate international cooperation and governance for sustained boundary current observations may be fruitful.

For any particular boundary current system, a complete observing system will require a combination of currently available observing platforms (see the section Observing Techniques), as well as future platforms, to optimally measure EOVs at necessary spatial and temporal resolutions to address relevant scientific and societal needs. Through the Framework process, specific observing platforms, sampling choices, and instruments would be matched to the relevant questions. Drifting and mobile assets that provide spatially resolved measurements at the expense of temporal resolution will need to be combined with moored assets that provide high-frequency measurements at key locations and land- or satellite-based remote sensing that provides spatially broad measurements of sea surface properties. Such integrated arrays, as are already in place in the California Current System, at the Ocean Observatories Initiative (OOI; Smith et al., 2018; Trowbridge et al., 2019) Endurance and Pioneer Arrays, and along the Australian coasts as part of the Integrated Marine Observing System, offer critical opportunities for intercalibration between instruments on fixed and mobile assets; such intercalibration is particularly important for biogeochemical sensors (e.g., Palevsky and Nicholson, 2018). Since similar needs arise in most boundary current systems, the Framework process should provide a means for determining the extent to which the same observing strategies should be applied to address similar needs in different systems. Additional studies that compare different sampling techniques in a given boundary current system could provide guidance on the strengths and limitations of each technique and how to better exploit their complementarity.

While the discussion of observing platforms in the section Observing Techniques focused on mature observing platforms with proven records of sustained operation in boundary currents, there is no doubt that recently developed observing platforms and sensing technology will become integral parts of future boundary current observing systems. For instance, more fast-moving autonomous underwater vehicles (AUVs) and autonomous surface vehicles (ASVs) will be deployed to conduct adaptive and targeted sampling in response to real-time needs. Propellerdriven AUVs have thus far seen limited use in boundary currents. Though able to carry large instrument payloads and move much faster $\left(1-2 \mathrm{~m} \mathrm{~s}^{-1}\right)$ than gliders, propeller-driven AUVs have been limited by battery endurance to missions typically lasting hours to days; improvements in battery technology and autonomous charging are expected to make propeller-driven vehicles capable of long-duration sampling in the near future. Fast-moving, longendurance ASVs (e.g., Saildrones and WaveGliders) are poised to become key platforms for making measurements near the air-sea interface, including meteorological measurements, $\mathrm{pCO}_{2}$, subsurface currents, and plankton biomass. Due to the use of renewable energy, these ASVs generally carry a larger number 
of sensors and have longer duration than other autonomous platforms (e.g., Zhang et al., 2017). Planned high-resolution, satellite-based altimetry measurements (e.g., SWOT), smaller and dramatically cheaper satellites (e.g., Cubesats), and, potentially, geostationary satellites positioned over boundary regions offer the prospect of dramatically increased spatial and temporal resolution of surface properties.

At some locations, boundary currents have been continuously observed for many years using various techniques. For instance, the CalCOFI program has maintained quarterly ship-based stations for more than 65 years (McClatchie, 2014), the WBTS has made cable- and ship-based measurements in the Florida Strait for more than 35 years (see the section Northwestern Atlantic), and hydrographic sampling has occurred monthly along the inside edge of the East Australian Current since the 1940s (Lynch et al., 2014) and is now an integral part of the East Australian Current observing system (Roughan and Morris, 2011). Long-term measurements like these are invaluable for capturing decadal variability and secular trends. Sites at which decades-long measurements exist should be maintained and serve as anchors for comprehensive boundary current observing systems. These long-term measurement sites at the boundaries also serve as points at which the boundary current observing systems are linked to the basin-scale ocean observing system. Since 2004, the WBTS has been integrated with the U.K.-U.S. RAPID-MOCHA program that measures meridional transport at $26.5^{\circ} \mathrm{N}$ in the North Atlantic, while several long-standing, crossPacific XBT transects intersect the U.S. West Coast within the CalCOFI domain (Goni et al., 2019).

Existing boundary current observing systems are largely focused on measuring physical processes, with biogeochemical and ecosystem processes only beginning to gain traction, largely due to the advent of new sensors. The California Current System (see the section California Current System) and Benguela (see the section Benguela Current System) are exceptions, having had sustained observations of EOVs relevant to physics, biogeochemistry, and biology and ecosystems for over 65 and 30 years, respectively. However, these ship-intensive models are unlikely to be suited to all boundary current systems due to a wide range of factors (e.g., cost, proximity to the coast, existing infrastructure, and available manpower). Although the methods for measuring many of the EOVs needed to monitor biogeochemical and, to a greater extent, ecosystem processes are time-intensive and require a platform for collecting water, new sensors are being developed to reliably measure a range of biogeochemical and biological EOVs. Many of these sensors have been successfully deployed on BGC-Argo floats as part of the SOCCOM project (Johnson et al., 2017). Increasing the measurements of biological and ecological EOVs should be prioritized if we are to understand, monitor, and predict the physical-biological connections and processes that support marine-based industries and activities and, importantly, seafood security.

Providing publicly available data in a timely manner is a key attribute of any ocean observing system. These observations should be provided in formats that are discoverable, accessible, and readily subset, following conventions agreed upon by the community (see Wilkinson et al. (2016) for a set of general principles for management of scientific data). Many platforms already provide observations in near real-time through a variety of services. Transmission of data through the Global Telecommunications System is particularly important if those observations are to be used in operational numerical modeling. Advances in real-time data collection from sub-surface moorings (e.g., Send et al., 2013) will be critical to providing boundary current observations in a timely manner for forecasting and prediction. Widespread dissemination of comprehensive boundary current observations can foster synergies with other disciplines, including the geophysics (tsunamis and earthquakes), physics, meteorological (e.g., tropical and extratropical cyclone forecasting; Domingues et al., 2019), and fisheries communities.

In addition to providing raw observations, there is a need for providing synthesized data products that are tailored to user needs. Integration of complementary data types can yield useful metrics. Further advances in data analysis techniques and statistical methods should aid in using multi-platform data to increase temporal and/or spatial resolution of metrics. The Southern California Temperature Index (Rudnick et al., 2017) is an example of such a data product.

Boundary current observations play a key role in constraining ocean models (e.g., Todd and Locke-Wynn, 2017), while models play a complementary role by filling gaps between sparse observations in a dynamically consistent manner (e.g., Todd et al., 2011b, 2012; Gopalakrishnan et al., 2013). Increased availability of boundary current observations, particularly in regions that are currently poorly sampled, should lead to continued improvements in regional models and predictive tools. At the same time, higher resolution climate models that can resolve boundary currents are becoming more plentiful and should begin to rely on high-resolution boundary current observations as constraints. One specific goal would be to reduce climate models' warm SST biases within EBCs; continuation and expansion of long-term measurements in EBCs as well as focused process studies to study upper ocean and atmospheric dynamics in EBCs would contribute to this goal. Observation impact studies derived from data assimilating models provide guidance on the value of a range of observation types in resolving boundary current transport, as well as for constraining the eddy field in ocean reanalyses (e.g., Kerry et al., 2016, 2018). It remains an open question how best to integrate models with interdisciplinary (e.g., biogeochemical) observations to study ecosystem dynamics, though advances are being made in the assimilation of biological parameters (e.g., Song et al., 2012). Observing System Simulation Experiments tailored for boundary current systems can also provide insight to the type, spatial distribution, and frequency of observations required to improve numerical simulations of boundary current dynamics (Hoffman and Atlas, 2016). Targeted observations can reduce biases in the initialization of models used to forecast extreme weather events and support local decision making (Halliwell et al., 2017).

Downscaling coarse resolution climate model predictions through the application of higher resolution regional and coastal models is now common and has shown promise but still faces research challenges. Furthermore, a significant amount 
of physical, biogeochemical, and biological response on the continental shelf is due to episodic oceanic and atmospheric events at timescales of variability that are absent from coarse models and cannot be recovered locally. To be valid globally, the veracity of downscaled models needs to be appraised by supporting observations of shelf edge fluxes in a diversity of circulation regimes.

Funding sustained observing efforts is a significant challenge. Portions of the observing system that have proven their readiness for long-term deployment have been discontinued after one or more short-term funding cycles. For instance, it is currently not clear how ship-time and funding challenges will be met for a reestablishment of ASCA (see the section Agulhas Current) in the future. In the typical 3-to-4-year cycles of scientific funding, early years (e.g., pilot phases) of observing efforts are readily fundable based on the promise of quick scientific results. Observing efforts that have endured for a decade or longer can leverage their long histories and clear relevance to decadal variability or secular trends to secure continued funding. The middle years, roughly years 4 through 10 as programs transition from pilot to mature components of the GOOS, are particularly difficult to fund.

The provision of robust three-dimensional and time-varying ocean circulation estimates in boundary current systems, resolving scales of a few kilometers, is seemingly within reach through advances in data-assimilative ocean models and rapid developments in observations platforms and sensors. However, the development of integrated observing systems that deliver the scope of observations required and the models capable of fully utilizing those observations is challenging. Success will require coordinated international collaborations, bringing together the expertise of the ocean modeling and observational communities. Establishment of an Ocean Boundary Task Team would provide a mechanism for the exchange of information regarding observing and model strategies, sensor developments, analysis techniques to combine data from the various observing platforms, and model development and application. The Task Team would also enable capacity building, encourage timely and appropriate transfer of knowledge, and provide a mechanism to instigate multinational observing systems with shared goals amongst participating nations. Endorsement of the Task Team by IOC/WMO or similar international organization is critical due to interests of multiple coastal state EEZs and the resulting complex governance needs.

\section{SUMMARY RECOMMENDATIONS}

The following actions are recommended to promote development of a comprehensive global network of boundary current observing systems in the next decade:

(1) Maintain existing long-term (i.e., multi-year) observational records;

(2) Expand the use of mobile, autonomous platforms (e.g., gliders, AUVs, and ASVs) to provide continuous, highresolution, broad-scale monitoring of EOVs;

(3) Deploy moored platforms at key locations to measure high-frequency variability;

(4) Continue and expand the provisioning of real-time observations and encourage post-processed data to be made publicly available as quickly as possible; data should be provided in readily discoverable formats that can easily be subset;

(5) Continue development and expand deployment of sensors for ecological and biogeochemical EOVs;

(6) Establish an Ocean Boundary Task Team to foster international community development and end-user engagement and to guide evolution of observing systems as user requirements change;

(7) Expand collaborations between observational efforts, modeling efforts, and societal users to meet stakeholder and end-user needs; and

(8) Increase focus on exchange between continental shelves and the deep ocean boundary currents to develop observing systems that span the continuum from the land to the deep ocean.

\section{AUTHOR CONTRIBUTIONS}

RT led the manuscript. Other lead authors (FC, SCl, SCr, MGo, MGr, XL, JS, and NZ) helped to conceive the manuscript and participated in all the stages of development. All authors provided input and/or edited the text.

\section{FUNDING}

RT was supported by The Andrew W. Mellon Foundation Endowed Fund for Innovative Research at WHOI. FC was supported by the David and Lucile Packard Foundation. MGo was funded by NSF and NOAA/AOML. XL was funded by China's National Key Research and Development Projects (2016YFA0601803), the National Natural Science Foundation of China (41490641, 41521091, and U1606402), and the Qingdao National Laboratory for Marine Science and Technology (2017ASKJ01). JS was supported by NOAA's Global Ocean Monitoring and Observing Program (Award NA15OAR4320071). DZ was partially funded by the Joint Institute for the Study of the Atmosphere and Ocean (JISAO) under NOAA Cooperative Agreement NA15OAR4320063. BS was supported by IMOS and CSIRO's Decadal Climate Forecasting Project. We gratefully acknowledge the wide range of funding sources from many nations that have enabled the observations and analyses reviewed here.

\section{ACKNOWLEDGMENTS}

We gratefully acknowledge the efforts of all parties involved in collecting, analyzing, and disseminating the wide-ranging observations discussed here. We thank the OCB Program, US CLIVAR, MBARI, and OMIX for supporting the Ocean Carbon Hot Spots Workshop, which facilitated the discussion of carbon cycle research in Western Boundary Current systems. We also gratefully acknowledge J. Hildebrandt (WHOI) for the assistance in editing the final manuscript. This is PMEL contribution \# 4890. 


\section{REFERENCES}

Adams, K., Barth, J. A., and Shearman, R. K. (2016). Intraseasonal cross-shelf variability of hypoxia along the Newport, Oregon, hydrographic line. J. Phys. Oceanogr. 46, 2219-2238. doi: 10.1175/JPO-D-15-0119.1

Alberty, M. S. (2018). Water Mass Transport and Transformation in the Tropics and Arctic. San Diego, CA: University of California. Available at: https:// escholarship.org/uc/item/9rf158pq

Alberty, M., Sprintall, J., MacKinnon, J., Germineaud, C., Cravatte, S., and Ganachaud, A. (2019). "Data from: moored observations of transport in the Solomon Sea," in Solomon Sea SPICE Mooring Data, (La Jolla, CA: UC San Diego Library Digital Collections), doi: 10.6075/J0639N12

Alford, M. H., Sloyan, B. M., and Simmons, H. L. (2017). Internal waves in the East Australian Current. Geophys. Res. Lett. 44, 12280-12288. doi: 10.1002/ 2017GL075246

Alin, S. R., Feely, R. A., Dickson, A. G., Hernández-Ayón, J. M., Juranek, L. W., Ohman, M. D., et al. (2012). Robust empirical relationships for estimating the carbonate system in the southern California Current System and application to CalCOFI hydrographic cruise data (2005-2011). J. Geophys. Res. Oceans 117:C05033. doi: 10.1029/2011JC007511

Álvarez-Salgado, X. A., Arístegui, J., Barton, E. D., and Hansell, D. A. (2007). Contribution of upwelling filaments to offshore carbon export in the subtropical Northeast Atlantic Ocean. Limnol. Oceanogr. 52, 1287-1292. doi: 10.4319/lo. 2007.52.3.1287

Andersson, A. J., Krug, L. A., Bates, N. R., and Doney, S. C. (2013). Sea-air CO2 flux in the North Atlantic subtropical gyre: role and influence of sub-tropical mode water formation. Deep Sea Res. Part II Top. Stud. Oceanogr. 91, 57-70. doi: $10.1016 /$ j.dsr2.2013.02.022

Andres, M. (2016). On the recent destabilization of the Gulf Stream path downstream of Cape Hatteras. Geophys. Res. Lett. 43, 9836-9842. doi: 10.1002/ 2016GL069966

Andres, M., Jan, S., Sanford, T. B., Mensah, V., Centurioni, L. R., and Book, J. W. (2015). Mean structure and variability of the Kuroshio from northeastern Taiwan to southwestern Japan. Oceanography 28, 84-95. doi: 10.5670/oceanog. 2015.84

Ansorge, I. J., Baringer, M. O., Campos, E. J. D., Dong, S., Fine, R. A., Garzoli, S. L., et al. (2014). Basin-wide oceanographic array bridges the South Atlantic. EOS 95, 53-54. doi: 10.1002/2014eo060001

Aoyama, M., Goto, H., Kamiya, H., Kaneko, I., Kawae, S., Kodama, H., et al. (2008). Marine biogeochemical response to a rapid warming in the main stream of the Kuroshio in the western North Pacific. Fish. Oceanogr. 17, 206-218. doi: $10.1111 / j .1365-2419.2008 .00473 . x$

Archer, M. R., Keating, S. R., Roughan, M., Johns, W. E., Lumkpin, R., BeronVera, F., et al. (2018). The kinematic similarity of two western boundary currents revealed by sustained high-resolution observations. Geophys. Res. Lett. 45, 6176-6185. doi: 10.1029/2018GL078429

Archer, M. R., Roughan, M., Keating, S. R., and Schaeffer, A. (2017a). On the variability of the East Australian Current: jet structure, meandering, and influence on shelf circulation. J. Geophys. Res. Oceans 122, 8464-8481. doi: 10.1002/2017JC013097

Archer, M. R., Shay, L. K., and Johns, W. E. (2017b). The surface velocity structure of the Florida Current in a jet coordinate frame. J. Geophys. Res. Oceans 122, 9189-9208. doi: 10.1002/2017JC013286

Archer, M. R., Shay, L. K., Jaimes, B., and Martinez-Pedraja, J. (2015). "Observing frontal instabilities of the Florida Current using high frequency radar," in Coastal Ocean Observing Systems, eds Y. Liu, H. Kerkering, and R. H. Weisberg (Amsterdam: Elsevier, Inc.), 179-208. doi: 10.1016/B978-0-12802022-7.00011-0

Arístegui, J., Alvarez-Salgado, X. A., Barton, E. D., Figueiras, F. G., HernándezLeón, S., Roy, C., et al. (2006). "Oceanography and fisheries of the Canary Current/Iberian region of the eastern North Atlantic," in The Sea, Vol. 14, eds A. R. Robinson and K. H. Brink (Cambridge, MA: Harvard University Press), 877-931.

Arístegui, J., Barton, E. D., Alvarez Salgado, X. A., Santos, A. M. P., Figueiras, F. G., Kifani, S., et al. (2009). Sub-regional ecosystem variability in the Canary Current upwelling. Prog. Oceanogr. 83, 33-48. doi: 10.1016/j.pocean.2009.07.031

Arístegui, J., Sangrà, P., Hernández-León, S., Cantón, M., Hernández Guerra, A., and Kerling, J. L. (1994). Island-induced eddies in the Canary
Islands. Deep Sea Res. I 41, 1509-1525. doi: 10.1016/0967-0637(94)90 058-2

Arístegui, J., Tett, P., Hernández-Guerra, A., Basterretxea, G., Montero, M. F., Wild, K., et al. (1997). The influence of island-generated eddies on chlorophyll distribution: a study of mesoscale variation around Gran Canaria. Deep Sea Res. 44, 71-96. doi: 10.1016/s0967-0637(96)00093-3

Artana, C., Ferrari, R., Koenig, Z., Saraceno, M., Piola, A. R., and Provost, C. (2016). Malvinas Current variability from argo floats and satellite altimetry. J. Geophys. Res. Oceans 121, 4854-4872. doi: 10.1002/2016JC011889

Artana, C., Ferrari, R., Koenig, Z., Sennechael, N., Saraceno, M., Piola, A. R., et al. (2018a). Malvinas Current volume transport at $41^{\circ} \mathrm{S}$ : a 24 yearlong time series consistent with mooring data from 3 decades and satellite altimetry. J. Geophys. Res. Oceans 123, 378-398. doi: 10.1002/2017JC013600

Artana, C., Lellouche, J., Park, Y., Garric, G., Koenig, Z., Sennéchael, N., et al. (2018b). Fronts of the Malvinas Current System: surface and subsurface expressions revealed by satellite altimetry, Argo floats, and Mercator operational model outputs. J. Geophys. Res. Oceans 123, 5261-5285. doi: 10. 1029/2018JC013887

Auad, G., Roemmich, D., and Gilson, J. (2011). The California Current System in relation to the northeast Pacific ocean circulation. Prog. Oceanogr. 91, 576-592. doi: $10.1016 /$ j.pocean.2011.09.004

Bacon, S., and Saunders, P. M. (2010). The deep western boundary current at Cape Farewell: results from a moored current meter array. J. Phys. Oceanogr. 40, 815-829. doi: 10.1175/2009jpo4091.1

Bakun, A., Black, B. A., Bograd, S. J., Garcia-Reyes, M., Miller, A. J., Rykaczewski, R. R., et al. (2015). Anticipated effects of climate change on coastal upwelling ecosystems. Curr. Clim. Change Rep. 1, 85-93. doi: 10.1007/s40641-015-0008-4

Bane, J. M., He, R., Muglia, M., Lowcher, C. F., Gong, Y., and Haines, S. M. (2017). Marine hydrokinetic energy from western boundary currents. Annu. Rev. Mar. Sci. 9, 105-123. doi: 10.1146/annurev-marine-010816-060423

Baringer, M. O., and Larsen, J. (2001). Sixteen years of Florida Current transport at 27N. Geophys. Res. Lett. 28, 3179-3182. doi: 10.1029/2001GL013246

Barton, A. D., Dutkiewicz, S., Flierl, G., Bragg, J., and Follows, M. J. (2010). Patterns of diversity in marine phytoplankton. Science 327, 1509-1511. doi: 10.1126/ science. 1184961

Barton, E. D., and Arístegui, J. (2004). The Canary Islands transition-upwelling, eddies and filaments. Prog. Oceanogr. 62, 67-69. doi: 10.1016/j.pocean.2004. 08.003

Barton, E. D., Arístegui, J., Tett, P., Cantón, M., García-Braun, J., Hernández-León, S., et al. (1998). The transition zone of the Canary Current upwelling region. Prog. Oceanogr. 41, 455-504. doi: 10.1016/s0079-6611(98)00023-8

Bates, N., Pequignet, A. C., Johnson, R. J., and Gruber, N. (2002). A variable sink for atmospheric $\mathrm{CO}_{2}$ in subtropical mode water of the North Atlantic Ocean. Nature 420, 489-493. doi: 10.1038/nature01253

Baumgartner, M. F., and Fratantoni, D. M. (2008). Diel periodicity in both sei whale vocalization rates and the vertical migration of their copepod prey observed from ocean gliders. Limnol. Oceanogr. 53, 2197-2209. doi: 10.4319/lo.2008.53. 5_part_2.2197

Beal, L. M., and Bryden, H. L. (1999). The velocity and vorticity structure of the Agulhas Current at $32^{\circ}$ S. J. Geophys. Res. 104, 5151-5176. doi: 10.1029/ 1998JC900056

Beal, L. M., and Elipot, S. (2016). Broadening not strengthening of the Agulhas Current since the early 1990s. Nature 540, 570-573. doi: 10.1038/nature19853

Beal, L. M., De Ruijter, W. P. M., Biastoch, A., Zahn, R., Cronin, M., Hermes, J., et al. (2011). On the role of the Agulhas system in ocean circulation and climate. Nature 472, 429-436. doi: 10.1038/nature09983

Beal, L. M., Elipot, S., Houk, A., and Leber, G. M. (2015). Capturing the transport variability of a western boundary jet: results from the Agulhas Current TimeSeries Experiment (ACT). J. Phys. Oceanogr. 45, 1302-1324. doi: 10.1175/JPOD-14-0119.1

Beal, L. M., Hormann, V., Lumpkin, R., and Foltz, G. R. (2013). The response of the surface circulation of the Arabian Sea to monsoonal forcing. J. Phys. Oceanogr. 43, 2008-2022. doi: 10.1175/JPO-D-13-033.1

Bednaršek, N., Feely, R. A., Beck, M. W., Glippa, O., Kanerva, M., and EngströmÖst, J. (2018). El Niño-related thermal stress coupled with upwelling-related ocean acidification negatively impacts cellular to population-level responses in pteropods along the California Current System with implications for increased bioenergetic costs. Front. Mar. Sci. 4:486. doi: 10.3389/fmars.2018.00486 
Bednaršek, N., Feely, R. A., Reum, J. C. P., Peterson, B., Menkel, J., Alin, S. R., et al. (2014). Limacina helicina shell dissolution as an indicator of declining habitat suitability owing to ocean acidification in the California Current Ecosystem. Proc. Biol. Sci. 281:20140123. doi: 10.1098/rspb.2014. 0123

Bednaršek, N., Feely, R. A., Tolimieri, N., Hermann, A. J., Siedlecki, S. A., Waldbusser, G. G., et al. (2017). Exposure history determines pteropod vulnerability to ocean acidification along the US West Coast. Sci. Rep. 7:4526. doi: 10.1038/s41598-017-03934-z

Benazzouz, A., Mordane, S., Orbi, A., Chagdali, M., Hilmi, K., Atillah, A., et al. (2014). An improved coastal upwelling index from sea surface temperature using satellite-based approach-the case of the Canary Current upwelling system. Cont. Shelf Res. 81, 38-54. doi: 10.1016/j.csr.2014.03.012

Bertrand, A., Chaigneau, A., Peraltilla, S., Ledesma, J., Graco, M., Monetti, F., et al. (2011). Oxygen: a fundamental property regulating pelagic ecosystem structure in the coastal southeastern tropical Pacific. PLoS One 6:e29558. doi: 10.1371/journal.pone.0029558

Bigorre, S. P., Weller, R. A., Edson, J. B., and Ware, J. D. (2013). A surface mooring for air-sea interaction research in the Gulf Stream. Part II: analysis of the observations and their accuracies. J. Atmos. Ocean. Technol. 30, 450-469. doi: 10.1175/JTECH-D-12-00078.1

Boebel, O., Lutjeharms, J., Schmid, C., Zenk, W., Rossby, T., and Barron, C. (2003). The cape cauldron: a regime of turbulent inter-ocean exchange. Deep Sea Res. Part II 50, 57-86. doi: 10.1016/S0967-0645(02)00379-X

Boening, C., Willis, J. K., Landerer, F. W., Nerem, R. S., and Fasullo, J. (2012). The 2011 La Niña: so strong, the oceans fell. Geophys. Res. Lett. 39:L19602. doi: 10.1029/2012GL053055

Bond, N. A., Cronin, M. F., Sabine, C., Kawai, Y., Ichikawa, H., Freitag, P., et al. (2011). Upper ocean response to Typhoon Choi-wan as measured by the Kuroshio Extension Observatory mooring. J. Geophys. Res. 116:C02031. doi: 10.1029/2010JC006548

Bowen, M., Markham, J., Sutton, P., Zhang, X., Wu, Q., Shears, N. T., et al. (2017). Interannual variability of sea surface temperature in the southwest Pacific and the role of ocean dynamics. J. Clim. 30, 7481-7492. doi: 10.1175/JCLI-D-160852.1

Bower, A. S., and Hunt, H. D. (2000a). Lagrangian observations of the Deep Western Boundary Current in the North Atlantic Ocean. Part I: large-scale pathways and spreading rates. J. Phys. Oceanogr. 30, 764-783. doi: 10.1175/ 1520-0485(2000)030<0764:lootdw>2.0.co;2

Bower, A. S., and Hunt, H. D. (2000b). Lagrangian observations of the Deep Western Boundary Current in the North Atlantic Ocean. Part II: the Gulf Stream-Deep Western Boundary Current crossover. J. Phys. Oceanogr. 30, 784-804. doi: 10.1175/1520-0485(2000)030<0784:lootdw>2.0.co;2

Brady, R. X., Lovenduski, N. S., Alexander, M. A., Jacox, M., and Gruber, N. (2019). On the role of climate modes in modulating the air-sea $\mathrm{CO}_{2}$ fluxes in eastern boundary upwelling systems. Biogeosciences 16, 329-346. doi: 10.5194/bg-16329-2019

Brandini, F. P., Boltovskoy, D., Piola, A., Kocmur, S., Röttgers, R., Abreu, P. C., et al. (2000). Multiannual trends in fronts and distribution of nutrients and chlorophyll in the southwestern Atlantic (30-62 S). Deep Sea Res. Part I 47, 1015-1033. doi: 10.1016/s0967-0637(99)00075-8

Brassington, G. B. (2010). Estimating surface divergence of ocean eddies using observed trajectories from a surface drifting buoy. J. Atmos. Ocean. Technol. 27, 705-720. doi: 10.1175/2009jtecho651.1

Brassington, G. B., Summons, N., and Lumpkin, R. (2011). Observed and simulated Lagrangian and eddy characteristics of the East Australian Current and the Tasman Sea. Deep Sea Res. 58, 559-573. doi: 10.1016/j.dsr2.2010.10.001

Bright, R. J., Xie, L., and Pietrafesa, L. J. (2002). Evidence of the Gulf Stream's influence on tropical cyclone intensity. Geophys. Res. Lett. 29:1801. doi: 10.1029/ 2002GL014920

Bushinsky, S. M., and Emerson, S. R. (2018). Biological and physical controls on the oxygen cycle in the Kuroshio Extension from an array of profiling floats. Deep Sea Res. I 141, 51-70. doi: 10.1016/j.dsr.2018.09.005

Bushinsky, S. M., Emerson, S. R., Riser, S. C., and Swift, D. D. (2016). Accurate oxygen measurements on modified Argo floats using in situ air calibrations. Limnol. Oceanogr. Methods 14, 491-505. doi: 10.1002/lom3.10107

Campagna, C., Piola, A. R., Marin, M. R., Lewis, M., and Fernández, T. (2006). Southern elephant seal trajectories, ocean fronts and eddies in the
Brazil/Malvinas Confluence. Deep Sea Res. I 53, 1907-1924. doi: 10.1016/j.dsr. 2006.08.015

Capet, X., Estrade, P., Machu, É., Ndoye, S., Grelet, J., Lazar, A., et al. (2017). On the dynamics of the southern Senegal upwelling center: observed variability from synoptic to superinertial scales. J. Phys. Oceanogr. 47, 155-180. doi: 10.1175/ JPO-D-15-0247.1

Carr, M.-E., and Kearns, E. J. (2003). Production regimes in four eastern boundary current systems. Deep Sea Res. II 50, 3199-3221. doi: 10.1016/j.dsr2.2003. 07.015

Castelao, R., Glenn, S., and Schofield, O. (2010). Temperature, salinity, and density variability in the central Middle Atlantic Bight. J. Geophys. Res. 115:C10005. doi: 10.1029/2009JC006082

Cavole, L. M., Demko, A. M., Diner, R. E., Giddings, A., Koester, I., Pagniello, C. M. L. S., et al. (2016). Biological impacts of the 2013-2015 warm-water anomaly in the Northeast Pacific: winners, losers, and the future. Oceanography 29, 273-285. doi: 10.5670/oceanog.2016.32

Cazenave, A., Dieng, H.-B., Meyssignac, B., von Schuckmann, K., Decharme, B., and Berthier, E. (2014). The rate of sea-level rise. Nat. Clim. Change 4, 358-361. doi: $10.1038 /$ nclimate2159

Centurioni, L. R. (2018). "Drifter technology and impacts for sea surface temperature, sea-level pressure, and ocean circulation studies," in Observing the Oceans in Real Time, eds R. Venkatesan, A. Tandon, E. D'Asaro, and M. A. Atmanand (Cham: Springer International Publishing), 37-57. doi: 10.1007/ 978-3-319-66493-4_3

Centurioni, L. R., and Niiler, P. P. (2003). On the surface currents of the Caribbean Sea. Geophys. Res. Lett. 30:1279. doi: 10.1029/2002GL016231

Centurioni, L. R., Hormann, V., Talley, L. D., Arzeno, I., Beal, L., Caruso, M., et al. (2017). Northern Arabian Sea Circulation-autonomous research (NASCar). A research initiative based on autonomous sensors. Oceanography 30, 74-87. doi: 10.5670/oceanog.2017.224

Centurioni, L. R., Niiler, P. N., and Lee, D.-K. (2009). Near-surface circulation in the South China Sea during the winter monsoon. Geophys. Res. Lett. 36:L06605. doi: 10.1029/2008GL037076

Centurioni, L. R., Niiler, P. P., and Lee, D.-K. (2004). Observations of inflow of Philippine sea surface water into the South China Sea through the Luzon Strait. J. Phys. Oceanogr. 34, 113-121. doi: 10.1175/1520-0485(2004)034<0113: ooiops $>2.0 . \mathrm{co} ; 2$

Centurioni, L. R., Ohlmann, J. C., and Niiler, P. P. (2008). Permanent meanders in the California Current System. J. Phys. Oceanogr. 38, 1690-1710. doi: 10.1175/ 2008JPO3746.1

Cetina Heredia, P., Roughan, M., Van Sebille, E., and Coleman, M. A. (2014). Longterm trends in the East Australian Current separation latitude and eddy driven transport. J. Geophys. Res. 119, 4351-4366. doi: 10.1002/2014JC010071

Chan, H. Y., Xu, W. Z., Shin, P. K. S., and Cheung, S. G. (2008). Prolonged exposure to low dissolved oxygen affects early development and swimming behaviour in the gastropod Nassarius festivus (Nassariidae). Mar. Biol. 153, 735-743. doi: 10.1007/s00227-007-0850-6

Chavez, F. P., and Messié, M. (2009). A comparison of eastern boundary upwelling ecosystems. Prog. Oceanogr. 83, 80-96. doi: 10.1016/j.pocean.2009.07.032

Chavez, F. P., and Toggweiler, J. R. (1995). "Physical estimates of global new production: the upwelling contribution," in Upwelling in the Ocean: Modern Processes and Ancient Records, eds C. P. Summerhayes, et al. (Hoboken, NJ: John Wiley), 313-320.

Chavez, F. P., Bertrand, A., Guevara, R., Soler, P., and Csirke, J. (2008). The northern Humboldt Current System: brief history, present status and a view towards the future. Prog. Oceanogr. 79, 95-105. doi: 10.1016/j.pocean.2008. 10.012

Checkley, D., and Barth, J. A. (2009). Patterns and processes in the California Current System. Prog. Oceanogr. 83, 49-64. doi: 10.1016/j.pocean.2009.07.028

Chen, K., Gawarkiewicz, G., and Plueddemann, A. J. (2018). Atmospheric and offshore forcing of temperature variability at the shelf break: observations from the OOI Pioneer Array. Oceanography 31, 72-79. doi: 10.5670/oceanog. 2018.112

Chen, Z., Wu, L., Qiu, B., Li, L., Hu, D., Liu, C., et al. (2015). Strengthening Kuroshio observed at its origin during November 2010 to October 2012. Oceans 120, 2460-2470. doi: 10.1002/2014JC010590

Claret, M., Galbraith, E. D., Palter, J. B., Bianchi, D., Fennel, K., Gilbert, D., et al. (2018). Rapid coastal deoxygenation due to ocean circulation shift in the 
northwest Atlantic. Nat. Clim. Chang. 8, 868-872. doi: 10.1038/s41558-0180263-1

Clayton, S., Dutkiewicz, S., Jahn, O., and Follows, M. J. (2013). Dispersal, eddies, and the diversity of marine phytoplankton. Limnol. Oceanogr. 3, 182-197. doi: 10.1215/21573689-2373515

Clayton, S., Lin, Y. C., Follows, M. J., and Worden, A. Z. (2017). Co-existence of distinct Ostreococcus ecotypes at an oceanic front. Limnol. Oceanogr. 62, 75-88. doi: 10.1002/lno.10373

Clayton, S., Nagai, T., and Follows, M. J. (2014). Fine scale phytoplankton community structure across the Kuroshio Front. J. Plankton Res. 36, 1017-1030. doi: $10.1093 /$ plankt/fbu020

Cockcroft, A. C., Schoeman, D. S., Pitcher, G. C., Bailey, G. W., and van Zyl, D. L. (2000). "A mass standing, or "walkout," of west coast rock lobster Jasus lalandii in Elands Bay, South Africa: causes, results and implications," in The Biodiversity Crisis and Crustacea, Vol. 12, eds J. C. von Kaupel Klein and F. R. Schram (Rotterdam: A. A. Balkema), 673-688.

Cockcroft, A. C., van Zyl, D., and Hutchings, L. (2008). Large-scale changes in the spatial distribution of South African West Coast rock lobsters: an overview. Afr. J. Mar. Sci. 30, 149-159. doi: 10.2989/ajms.2008.30.1.15.465

Colas, F., Capet, X., McWilliams, J. C., and Shchepetkin, A. (2008). 1997-1998 El Niño off Peru: a numerical study. Prog. Oceanogr. 79, 138-155.

Colas, F., McWilliams, J. C., Capet, X., and Kurian, J. (2012). Heat balance and eddies in the Peru-Chile current system. Clim. Dyn. 39, 509-529. doi: 10.1007/ s00382-011-1170-6

Conway, T. M., Palter, J. B., and de Souza, G. F. (2018). Gulf Stream rings as a source of iron to the North Atlantic subtropical gyre. Nat. Geosci. 11, 594-598. doi: 10.1038/s41561-018-0162-0

Cravatte, S., Ganachaud, A., Sprintall, J., Alberty, M., Germineaud, C., Brachet, C., et al. (2019). Solomon Sea SPICE Mooring Data. La Jolla, CA: UC San Diego Library Digital Collections, doi: 10.6075/J09W0CS2

Cronin, M. F., Bond, N. A., Farrar, J. T., Ichikawa, H., Jayne, S. R., Kawai, Y., et al. (2013). Formation and erosion of the seasonal thermocline in the Kuroshio Extension recirculation gyre. Deep Sea Res. 85, 62-74. doi: 10.1016/j.dsr2.2012. 07.018

Cronin, M. F., Gentemann, C. L., Edson, J., Ueki, I., Bourassa, M., Brown, S., et al. (2019). Air-sea fluxes with a focus on heat and momentum. Front. Mar. Sci. 6:430. doi: 10.3389/fmars.2019.00430

Cronin, M. F., Pelland, N. A., Emerson, S. R., and Crawford, W. R. (2015). Estimating diffusivity from the mixed layer heat and salt balances in the North Pacific. J. Geophys. Res. Oceans 120, 7346-7362. doi: 10.1002/2015JC011010

D'Adamo, N., Fandry, C., Bubarton, S., and Domingues, C. (2009). Northern sources of the Leeuwin Current and the "Holloway Current" on the North West Shelf. J. R. Soc. West Aust. 92, 53-66.

da Silveira, I. C. A., deMiranda, L. B., and Brown, W. S. (1994). On the origins of the North Brazil Current. J. Geophys. Res. 99, 22501-22512. doi: 10.1029/ 94JC01776

Davis, R. (2016). Data From: Solomon Sea Ocean Transport From Gliders. La Jolla, CA: Scripps Institution of Oceanography, Instrument Development Group, doi: 10.21238/s8SPRAY2718

Davis, R. E., Kessler, W. S., and Sherman, J. T. (2012). Gliders measure western boundary current transport from the South Pacific to the Equator. J. Phys. Oceanogr. 42, 2001-2013. doi: 10.1175/JPO-D-12-022.1

de Ruijter, W. P. M., Biastoch, A., Drijfhout, S. S., Lutjeharms, J. R. E., Matano, R. P., Pichevin, T., et al. (1999). Indian-Atlantic interocean exchange: dynamics, estimation and impact. J. Geophys. Res. 104, 20885-20910. doi: 10.1029/ 1998JC900099

Dengler, M., Fischer, J., Schott, F. A., and Zantopp, R. (2006). Deep Labrador Current and its variability in 1996-2005. Geophys. Res. Lett. 33:L21S06. doi: 10.1029/2006GL026702

Dever, M., Hebert, D., Greenan, B. J. W., Sheng, J., and Smith, P. C. (2016). Hydrography and coastal circulation along the Halifax Line and the connections with the Gulf of St. Lawrence. Atmos. Ocean 54, 199-217. doi: 10.1080/ 07055900.2016.1189397

DeVries, T. (2014). The oceanic anthropogenic $\mathrm{CO}_{2}$ sink: storage, air-sea fluxes, and transports over the industrial era. Glob. Biogeochem. Cycles 28, 631-647. doi: 10.1002/2013GB004739

Dewitte, B., Vazquez-Cuervo, J., Goubanova, K., Illig, S., Takahashi, K., Cambon, G., et al. (2012). Change in El Niño flavours over 1958-2008: implications for the long-term trend of the upwelling off Peru. Deep Sea Res. Part II 77, $143-156$.
deYoung, B., von Oppeln-Bronikowski, N., Matthews, J. B. R., and Bachmayer, R. (2018). Glider operations in the Labrador Sea. J. Ocean Tech. 13, 108-120.

Di Lorenzo, E., and Mantua, N. (2016). Multi-year persistence of the 2014/15 North Pacific marine heatwave. Nat. Clim. Change 6, 1042-1047. doi: 10.1038/ nclimate 3082

Diakhaté, M., de Coëtlogon, G., Lazar, A., Wade, M., and Gaye, A. T. (2016). Intraseasonal variability of tropical Atlantic sea-surface temperature: air-sea interaction over upwelling fronts. Q. J. R. Meteorol. Soc. 142, 372-386. doi: 10.1002/qj.2657

Domingues, C. M., Wijffels, S. E., Maltrud, M. E., Church, J. A., and Tomczak, M. (2006). Role of eddies in cooling the Leeuwin Current. Geophys. Res. Lett. 33:L05603. doi: 10.1029/2005GL025216

Domingues, R., Baringer, M., and Goni, G. (2016). Remote sources for year-to-year changes in the seasonality of the Florida Current transport. J. Geophys. Res. 121, 7547-7559. doi: 10.1002/2016JC012070

Domingues, R., Goni, G., Baringer, M., and Volkov, D. L. (2018). What caused the accelerated sea level changes along the United States East Coast during 2010-2015? Geophys. Res. Lett. 45, 13367-13376. doi: 10.1029/2018GL081183

Domingues, R., Kuwano-Yoshida, A., Chardon-Maldonado, P., Todd, R. E., Halliwell, G. R., Kim, H.-S., et al. (2019). Ocean observations in support of studies and forecasts of tropical and extratropical cyclones. Front. Mar. Sci. 6:446. doi: 10.3389/fmars.2019.00446

Dong, S., Goni, G., and Bringas, F. (2015). Temporal variability of the south Atlantic Meridional Overturning Circulation between $20^{\circ} \mathrm{S}$ and $35^{\circ} \mathrm{S}$. Geophys. Res. Lett. 42, 7655-7662. doi: 10.1002/2015GL065603

Donohue, K. A., Watts, D. R., Tracey, K. L., Greene, A. D., and Kennelly, M. (2010). Mapping circulation in the Kuroshio Extension with an array of current and pressure recording inverted echo sounders. J. Atmos. Ocean. Technol. 27, 507-527. doi: 10.1175/2009JTECHO686.1

Douglass, E., Roemmich, D., and Stammer, D. (2010). Interannual variability in North Pacific heat and freshwater budgets. Deep Sea Res. Part II 57, 1127-1140. doi: 10.1016/j.dsr2.2010.01.001

Duncombe Rae, C. M. (2005). A demonstration of the hydrographic partition of the Benguela upwelling ecosystem at $26^{\prime} 40^{\circ}$ S. Afr. J. Mar. Sci. 27, 617-628. doi: $10.2989 / 18142320509504122$

Elipot, S., and Beal, L. M. (2015). Characteristics, energetics, and origins of Agulhas Current meanders and their limited influence on ring shedding. J. Phys. Oceanogr. 45, 2294-2314. doi: 10.1175/JPO-D-14-0254.1

Elipot, S., and Beal, L. M. (2018). Observed Agulhas Current sensitivity to interannual and long-term trend atmospheric forcings. J. Clim. 31, 3077-3098. doi: 10.1175/JCLI-D-17-0597.1

Escribano, R., and Morales, C. E. (2012). Spatial and temporal scales of variability in the coastal upwelling and coastal transition zone off central-southern Chile (35-40 S). Progr. Oceanogr. 92, 1-7. doi: 10.1016/j.pocean.2011.07.019

Espinoza, P., Lorrain, A., Ménard, F., Cherel, Y., Tremblay-Boyer, L., Argüelles, J., et al. (2017). Trophic structure in the northern Humboldt Current System: new perspectives from stable isotope analysis. Mar. Biol. 164:86. doi: 10.1007/ s00227-017-3119-8

Everett, J. D., Baird, M. E., Roughan, M., Suthers, I. M., and Doblin, M. A. (2014). Relative impact of seasonal and oceanographic drivers on surface chlorophyll a along a Western Boundary Current. Prog. Oceanogr. 120, 340-351. doi: 10. 1016/j.pocean.2013.10.016

Ezer, T. (2015). Detecting changes in the transport of the Gulf Stream and the Atlantic overturning circulation from coastal sea level data: the extreme decline in 2009-2010 and estimated variations for 1935-2012, Global Planet. Change 129, 23-36. doi: 10.1016/j.gloplacha.2015.03.002

Fassbender, A. J., Alin, S. R., Feely, R. A., Sutton, A. J., Newton, J. A., Krembs, C., et al. (2018). Seasonal carbonate chemistry variability in marine surface waters of the US Pacific Northwest. Earth Syst. Sci. Data 10, 1367-1401. doi: 10.5194/essd-10-1367-2018

Fassbender, A. J., Alin, S. R., Feely, R. A., Sutton, A. J., Newton, J. A., and Byrne, R. H. (2017a). Estimating total alkalinity in the Washington State coastal zone: complexities and surprising utility for ocean acidification research. Estuar. Coast. 40, 404-418. doi: 10.1007/s12237-016-0168-z

Fassbender, A. J., Sabine, C. L., Cronin, M. F., and Sutton, A. J. (2017b). Mixedlayer carbon cycling at the Kuroshio extension observatory. Glob. Biogeochem. Cycles 31, 272-288. doi: 10.1002/2016GB005547

Fassbender, A. J., Sabine, C. L., and Feifel, K. M. (2016). Consideration of coastal carbonate chemistry in understanding biological calcification. Geophys. Res. Lett. 43, 4467-4476. doi: 10.1002/2016gl068860 
Fassbender, A. J., Sabine, C. L., Feely, R. A., Langdon, C., and Mordy, C. W. (2011). Inorganic carbon dynamics during northern California coastal upwelling. Cont. Shelf Res. 31, 1180-1192. doi: 10.1016/j.csr.2011.04.006

Faye, S., Lazar, A., Sow, B. A., and Gaye, A. T. (2015). A model study of the seasonality of sea surface temperature and circulation in the Atlantic northeastern tropical upwelling system. Front. Phys. 3:76. doi: 10.3389/fphy.2015. 00076

Feely, R. A., Alin, S., Carter, B., Bednaršek, N., Hales, B., Chan, F., et al. (2016). Chemical and biological impacts of ocean acidification along the west coast of North America. Estuar. Coast. Shelf Sci. 183, 260-270. doi: 10.1016/j.ecss.2016. 08.043

Feely, R. A., Okazaki, R. R., Cai, W.-J., Bednaršek, N., Alin, S. R., Byrne, R. H., et al. (2018). The combined effects of acidification and hypoxia on $\mathrm{pH}$ and aragonite saturation in the coastal waters of the California Current Ecosystem and the northern Gulf of Mexico. Cont. Shelf Res. 152, 50-60. doi: 10.1016/j.csr.2017. 11.002

Feely, R. A., Sabine, C. L., Hernandez-Ayon, J. M., Ianson, D., and Hales, B. (2008). Evidence for upwelling of corrosive 'acidified' water onto the continental shelf. Science 320, 1490-1492. doi: 10.1126/science.1155676

Feng, M., Hendon, H. H., Xie, S. P., Marshall, A. G., Schiller, A., Kosaka, Y., et al. (2015). Decadal increase in Ningaloo Niño since the late 1990s. Geophys. Res. Lett. 42, 104-112. doi: 10.1002/2014GL062509

Feng, M., McPhaden, M. J., Xie, S. P., and Hafner, J. (2013). La Niña forces unprecedented Leeuwin Current warming in 2011. Sci. Rep. 3:1277. doi: 10. 1038/srep01277

Feng, M., Meyer, G., Pearce, A., and Wijffels, S. (2003). Annual and interannual variations of the Leeuwin Current at 32S. J. Geophys. Res. 108:3355. doi: 10. 1029/2002JC001763

Fennel, K., Wilkin, J., Levin, J., Moisan, J., O’Reilly, J., and Haidvogel, D. (2006). Nitrogen cycling in the middle atlantic bight: results from a threedimensional model and implications for the North Atlantic nitrogen budget. Glob. Biogeochem. Cycles 20:GB3007. doi: 10.1029/2005GB002456

Fernandez, D., Bowen, M., and Sutton, P. (2018). Variability, coherence and forcing mechanisms in the New Zealand ocean boundary currents. Prog. Oceanogr. 165, 1680-1688. doi: 10.1016/j.pocean.2018.06.002

Ferrari, R., Artana, C., Saraceno, M., Piola, A. R., and Provost, C. (2017). Satellite altimetry and current-meter velocities in the Malvinas Current at $41^{\circ} \mathrm{S}$ : comparisons and modes of variations. J. Geophys. Res. 122, 9572-9590. doi: 10.1002/2017JC013340

Fischer, J., Schott, F., and Dengler, M. (2004). Boundary circulation at the exit of the Labrador Sea. J. Phys. Oceanogr. 34, 1548-1570. doi: 10.1175/1520-0485(2004) $034<1548$ :bcateo $>2.0$. co; 2

Fischer, J., Visbeck, M., Zantopp, R., and Nunes, N. (2010). Interannual to decadal variability of outflow from the Labrador Sea. Geophys. Res. Lett. 37:L24610. doi: 10.1029/2010GL045321

Frajka-Williams, E., Ansorge, I. J., Baehr, J., Bryden, H. L., Chidichimo, M. P., Cunningham, S. A., et al. (2019). Atlantic Meridional Overturning Circulation: observed transport and variability. Front. Mar. Sci. 6:260. doi: 10.3389/fmars. 2019.00260

Fratantoni, D. M., and Richardson, P. L. (2006). The evolution and demise of North Brazil current rings. J. Phys. Oceanogr. 36, 1241-1264. doi: 10.1175/JPO 2907.1

Fratantoni, P. S., and Pickart, R. S. (2007). The western North Atlantic shelfbreak current system in summer. J. Phys. Oceanogr. 37, 2509-2533. doi: 10.1175/ JPO3123

Fréon, P., Coetzee, J. C., Van der Lingen, C. D., Connell, A. D., O’Donoghue, S. H., Roberts, M. J., et al. (2010). A review and tests of hypotheses about causes of the KwaZulu-Natal sardine run. Afr. J. Mar. Sci. 32, 449-479. doi: 10.2989/1814232X.2010.519451

Friederich, G. E., Walz, P. M., Burczynski, M. G., and Chavez, F. P. (2002). Inorganic carbon in the central California upwelling system during the 19971999 El Niño-La Niña event. Prog. Oceanogr. 54, 185-203. doi: 10.1016/S00796611(02)00049-6

Frölicher, T. L., and Laufkötter, C. (2018). Emerging risks from marine heat waves. Nat. Commun. 9:650. doi: 10.1038/s41467-018-03163-6

Fujioka, K., Fukuda, H., Furukawa, S., Tei, Y., Okamoto, S., and Ohshimo, S. (2018). Habitat use and movement patterns of small (age-0) juvenile Pacific bluefin tuna (Thunnus orientalis) relative to the Kuroshio. Fish. Oceanogr. 27, 185-198. doi: $10.1111 /$ fog. 12244
Furue, R., Guerreiro, K., Phillips, H. E., McCreary, J. P., and Bindoff, N. (2017). On the Leeuwin Current system and its linkage to zonal flows in the South Indian ocean as inferred from a gridded hydrography. J. Phys. Oceanogr. 47, 583-602. doi: 10.1175/JPO-D-16-0170.1

Galarneau, T. J. Jr., Davis, C. A., and Shapiro, M. A. (2013). Intensification of Hurricane Sandy (2012) through extratropical warm core seclusion. Mon. Weather Rev. 141, 4296-4321. doi: 10.1175/MWR-D-13-00181.1

Ganachaud, A., Cravatte, S., Melet, A., Schiller, A., Holbrook, N. J., Sloyan, B. M., et al. (2014). The Southwest Pacific Ocean Circulation and Climate Experiment (SPICE). J. Geophys. Res. Oceans 119, 7660-7686. doi: 10.1002/2013JC00967

Ganachaud, A., Cravatte, S., Sprintall, J., Germineaud, C., Alberty, M., Jeandel, C., et al. (2017). The Solomon Sea: its circulation, chemistry, geochemistry and biology explored during two oceanographic cruises. Elem. Sci. Anth. 5:33. doi: 10.1525/elementa.221

Garzoli, S. L., Baringer, M. O., Dong, S., Perez, R. C., and Yao, Q. (2012). South Atlantic meridional fluxes. Deep Sea Res. Part I 71, 21-32. doi: 10.1016/j.dsr. 2012.09.003

Gaube, P., Braun, C. D., Lawson, G. L., McGillicuddy, D. J., Della Penna, A., Skomal, G., et al. (2018). Mesoscale eddies influence the movements of mature female white sharks in the Gulf Stream and Sargasso Sea. Sci. Rep. 8:7363. doi: 10.1038/s41598-018-25565-8

Gawarkiewicz, G. G., and Linder, C. A. (2006). Lagrangian flow patterns north of Cape Hatteras using near-surface drifters. Prog. Oceanogr. 70, 181-195. doi: 10.1016/j.pocean.2006.03.020

Gawarkiewicz, G., Todd, R. E., Zhang, W., Partida, J., Gangopadhyay, A., Monim, M.-U.-H., et al. (2018). The changing nature of shelf-break exchange revealed by the OOI Pioneer Array. Oceanography 31, 60-70. doi: 10.5670/oceanog. 2018.110

Gay, P. S., and Chereskin, T. K. (2009). Mean structure and seasonal variability of the poleward undercurrent off southern California. J. Geophys. Res. 114:C02007. doi: 10.1029/2008JC004886

Godfrey, J. S., and Weaver, A. J. (1991). Is the Leeuwin current driven by Pacific heating and winds? Prog. Oceanogr. 27, 225-272. doi: 10.1016/0079-6611(91) 90026-I

Gómez-Letona, M., Ramos, A. G., Coca, J., and Arístegui, J. (2017). Trends in primary production in the Canary Current upwelling system-a regional perspective comparing remote sensing models. Front. Mar. Sci. 4:370. doi: 10.3389/fmars.2017.00370

Goni, G. J., Sprintall, J., Bringas, F., Cheng, L., Cirano, M., Dong, S., et al. (2019). More than 50 years of continuous temperature section measurements by the Global Expendable Bathythermograph (XBT) Network, its integrability, societal benefits, and future. Front. Mar. Sci. 6:452. doi: 10.3389/fmars.2019.00452

Gopalakrishnan, G., Cornuelle, B. D., Hoteit, I., Rudnick, D. L., and Owens, W. B. (2013). State estimates and forecasts of the Loop Current in the Gulf of Mexico using the MITgcm and its adjoint. J. Geophys. Res. 118, 3292-3314. doi: $10.1002 /$ jgrc.20239

Gordon, A. L., Flament, P., Villanoy, C., and Centurioni, L. (2014). The nascent Kuroshio of Lamon Bay. J. Geophys. Res. 119, 4251-4263. doi: 10.1002/ 2014JC009882

Gorgues, T., Aumont, O., and Rodgers, K. B. (2010). A mechanistic account of increasing seasonal variations in the rate of ocean uptake of anthropogenic carbon. Biogeosciences 7, 2581-2589. doi: 10.5194/bg-7-2581-2010

Graco, M., Purca, S., Dewitte, B., Castro, C., Morón, O., Ledesma, J., et al. (2017). The OMZ and nutrient features as a signature of interannual and low-frequency variability in the Peruvian upwelling system. Biogeosciences 14, 4601-4617. doi: 10.5194/bg-14-1-2017

Grados, C., Chaigneau, A., Echevin, V., and Dominguez, N. (2018). Upper ocean hydrology of the northern Humboldt Current System at seasonal, interannual and interdecadal scales. Prog. Oceanogr. 165, 123-144. doi: 10.1016/j.pocean. 2018.05.005

Gruber, N., Keeling, C. D., and Bates, N. R. (2002). Interannual variability in the North Atlantic Ocean carbon sink. Science 298, 2374-2378. doi: 10.1126/ science. 1077077

Guerrero, R. A., Piola, A. R., Fenco, H., Matano, R. P., Combes, V., Chao, Y., et al. (2014). The salinity signature of the cross-shelf exchanges in the Southwestern Atlantic Ocean: satellite observations. J. Geophys. Res. Oceans 119, 7794-7810. doi: 10.1002/2014JC010113

Gula, J., Blacic, T. M., and Todd, R. E. (2019). Submesoscale coherent vortices in the Gulf Stream. Geophys. Res. Lett. 46, 2704-2714. doi: 10.1029/2019GL081919 
Guo, X. Y., Zhu, X. H., Long, Y., and Huang, D. J. (2013). Spatial variations in the Kuroshio nutrient transport from the East China Sea to south of Japan. Biogeosciences 10, 6403-6417. doi: 10.5194/bg-10-6403-2013

Guo, X., Zhu, X. H., Wu, Q. S., and Huang, D. (2012). The Kuroshio nutrient stream and its temporal variation in the East China Sea. J. Geophys. Res. Oceans 117:C01026. doi: 10.1029/2011JC007292

Gutiérrez, D. (2016). Variabilidad climática, procesos oceanográficos y producción primaria frente al Perú. Boletín Técnico "Generación de información y monitoreo del Fenómeno El Niño.”. Instituto Geofísico del Perú 3, 4-8.

Haines, S., Seim, H., and Muglia, M. (2017). Implementing quality control of highfrequency radar estimates and application to Gulf Stream surface currents. J. Atmos. Ocean. Technol. 34, 1207-1224. doi: 10.1175/JTECH-D-16-0203.1

Hales, B., Takahashi, T., and Bandstra, L. (2005). Atmospheric $\mathrm{CO}_{2}$ uptake by a coastal upwelling system. Glob. Biogeochem. Cycles 19:GB1009. doi: 10.1029/ 2004GB002295

Halliwell, G. R., Mehari, M., Shay, L. K., Kourafalou, V. H., Kang, H., Kim, J.-S., et al. (2017). OSSE quantitative assessment of rapid-response prestorm ocean surveys to improve coupled tropical cyclone prediction. J. Geophys. Res. Oceans 122, 5729-5748. doi: 10.1002/2017JC012760

Hansen, D. V., and Poulain, P.-M. (1996). Quality control and interpolation of WOCE/TOGA drifter data. J. Atmos. Ocean. Technol. 13, 900-909. doi: 10. 1175/1520-0426(1996)013<0900:qcaiow >2.0.co;2

Harris, K. E., DeGrandpre, M. D., and Hales, B. (2013). Aragonite saturation states in a coastal upwelling zone. Geophys. Res. Lett. 40, 2720-2725. doi: 10.1002/grl. 50460

He, R., Chen, K., Moore, T., and Li, M. (2010). Mesoscale variations of sea surface temperature and ocean color patterns at the Mid-Atlantic Bight shelfbreak. Geophys. Res. Lett. 37:L09607. doi: 10.1029/2010GL042658

Helly, J. J., and Levin, L. A. (2004). Global distribution of naturally occurring marine hypoxia on continental margins. Deep Sea Res. I 51, 1159-1168. doi: 10.1016/j.dsr.2004.03.009

Henderikx Freitas, F., Saldiìas, G. S., Goñi, M., Shearman, R. K., and White, A. E. (2018). Temporal and spatial dynamics of physical and biological properties along the Endurance Array of the California Current Ecosystem. Oceanography 31, 80-89. doi: 10.5670/oceanog.2018.113

Henderikx Freitas, F., Siegel, D. A., Washburn, L., Halewood, S., and Stassinos, E. (2016). Assessing controls on cross-shelf phytoplankton and suspended particle distributions using repeated bio-optical glider surveys. Oceans 121, 7776-7794. doi: 10.1002/2016JC011781

Heslop, E. E., Ruiz, S., Allen, J., López-Jurado, J. L., Renault, L., and Tintoré, J. (2012). Autonomous underwater gliders monitoring variability at "choke points" in our ocean system: a case study in the Western Mediterranean Sea. Geophys. Res. Lett. 39:L20604.

Hill, K., Moltmann, T., Meyers, G., and Proctor, R. (2010). "The Australian integrated marine observing system (IMOS)," in Proceedings of OceanObs'09: Sustained Ocean Observations and Information for Society, eds J. Hall, D. E. Harrison, and D. Stammer (Venice: ESA Publication WPP-306), doi: 10.5270/ OceanObs09

Hill, K., Rintoul, S. R., Ridgway, K. R., and Oke, P. R. (2011). Decadal changes in the South Pacific western boundary current system revealed in observations and ocean state estimates. J. Geophys. Res. 116:C01009. doi: 10.1029/2009JC005926

Hobday, A. J., Alexander, L. V., Perkins, S. E., Smale, D. A., Straub, S. C., Oliver, E. C. J., et al. (2016). A hierarchical approach to defining marine heatwaves. Prog. Oceanogr. 141, 227-238. doi: 10.1016/j.pocean.2015.12.014

Hoffman, R. N., and Atlas, R. (2016). Future observing system simulation experiments. Bull. Am. Meteor. Soc. 97, 1601-1616. doi: 10.1175/BAMS-D-1500200.1

Honda, M. C., Sasai, Y., Siswanto, E., Kuwano-Yoshida, A., Aiki, H., and Cronin, M. F. (2018). Impact of cyclonic eddies and typhoons on biogeochemistry in the oligotrophic ocean based on biogeochemical/physical/meteorological timeseries at station KEO. Prog. Earth Planet. Sci. 5:42. doi: 10.1186/s40645-0180196-3

Houpert, L., Inall, M. E., Dumont, E., Gary, S., Johnson, C., Porter, M., et al. (2018). Structure and transport of the North Atlantic Current in the eastern subpolar gyre from sustained glider observations. J. Geophys. Res. Oceans 123, 6019-6038. doi: 10.1029/2018JC014162

Howatt, T., Palter, J. B., Matthews, J. B., deYoung, B., Bachmayer, R., and Claus, B. (2018). Ekman and eddy exchange of freshwater and oxygen across the
Labrador Shelf Break. J. Phys. Oceanogr. 48, 1015-1031. doi: 10.1175/JPO-D17-0148.1

Hu, D., Hu, S., Wu, L., Li, L., Zhang, L., Diao, X., et al. (2013). Direct measurements of the Luzon undercurrent. J. Phys. Oceanogr. 43, 1417-1425. doi: 10.1175/JPOD-12-0165.1

Hu, D., Wu, L., Cai, W., Sen Gupta, A., Ganachaud, A., Qiu, B., et al. (2015). Pacific western boundary currents and their roles in climate. Nature 522, 299-308. doi: 10.1038/nature14504

Hu, S., Hu, D., Guan, C., Wang, F., Zhang, L., Wang, F., et al. (2016). Interannual variability of the Mindanao Current/Undercurrent in direct observations and numerical simulations. J. Phys. Oceanogr. 46, 483-499. doi: 10.1175/JPO-D-150092.1

Hummels, R., Brandt, P., Dengler, M., Fischer, J., Araujo, M., Veleda, D., et al. (2015). Interannual to decadal changes in the western boundary circulation in the Atlantic at 11 degrees S. Geophys. Res. Lett. 42, 7615-7622. doi: 10.1002/ 2015 gl065254

Hutchings, L., Augustyn, C. J., Cockcroft, A., Van der Lingen, C., Coetzee, J., Leslie, R. W., et al. (2009a). Marine fisheries monitoring programmes in South Africa. S. Afr. J. Sci. 105, 182-192.

Hutchings, L., Roberts, M. J., and Verheye, H. M. (2009b). Marine environmental monitoring programmes in South Africa: a review. S. Afr. J. Sci. 105, 94-102.

Hutchings, L., van der Lingen, C., Shannon, L. J., Cawford, R. J. M., Verheye, H. M., Bartholomae, C. H., et al. (2009c). The Benguela Current: an ecosystem of four components. Progr. Oceanogr. 83, 15-32. doi: 10.1016/j.pocean.2009. 07.046

Huyer, A., Wheeler, P. A., Strub, P. T., Smith, R. L., Letelier, R., and Kosro, P. M. (2007). The Newport Line off Oregon-studies in the northeast Pacific. Prog. Oceanogr. 75, 126-160. doi: 10.1016/j.pocean.2007.08.003

Ichikawa, H., Nakamura, H., Nishina, A., and Higashi, M. (2004). Variability of northeastward current southeast of Northern Ryukyu Islands. J. Oceanogr. 60, 351-363. doi: 10.1023/B:JOCE.0000038341.27622.73

Imawaki, S., Bower, A., Beal, L., and Qiu, B. (2013). "Western boundary currents," in Ocean Circulation and Climate - a 21st Century Perspective, eds G. Siedler, S. M. Griffies, J. Gould, and J. A. Church (Amsterdam: Elsevier Academic Press), 305-338. doi: 10.1016/B978-0-12-391851-2.00013-1

Imawaki, S., Uchida, H., Ichikawa, H., Fuksawa, M., Umatani, S., and The Asuka group. (2001). Satellite altimeter monitoring the Kuroshio transport south of Japan. Geophys. Res. Lett. 28, 17-20. doi: 10.1029/2000GL011796

Inoue, R., Honda, M., Fujiki, T., Matsumoto, K., Kouketsu, S., Suga, T., et al. (2016a). Western North Pacific integrated physical-biogeochemical ocean observation experiment (INBOX): Part 2. Biogeochemical responses to eddies and typhoons revealed from the S1 mooring and shipboard measurements. J. Mar. Res. 74, 71-99. doi: 10.1357/002224016819257335

Inoue, R., Suga, T., Kouketsu, S., Kita, T., Hosoda, S., Kobayashi, T., et al. (2016b). Western north Pacific integrated physical-biogeochemical ocean observation experiment (INBOX): Part 1. Specifications and chronology of the S1-INBOX floats. J. Mar. Res. 74, 43-69. doi: 10.1357/002224016819257344

Ito, S., Yoshie, N., Okunishi, T., Ono, T., Okazaki, Y., Kuwataet, A., et al. (2010). Application of an automatic approach to calibrate the NEMURO nutrientphytoplankton-zooplankton food web model in the Oyashio region. Progr. Oceanogr. 87, 186-200. doi: 10.1016/j.pocean.2010.08.004

Ito, T., and Follows, M. J. (2003). Upper ocean control on the solubility pump of $\mathrm{CO}_{2}$. J. Mar. Res. 61, 465-489. doi: 10.1357/002224003322384898

Iudicone, D., Rodgers, K. B., Plancherel, Y., Aumont, O., Ito, T., Key, R. M., et al. (2016). The formation of the ocean's anthropogenic carbon reservoir. Sci. Rep. 6:35473. doi: $10.1038 /$ srep35473

Jayne, S. R., Roemmich, D., Zilberman, N., Riser, S. C., Johnson, K. S., Johnson, G. C., et al. (2017). The Argo program: present and future. Oceanography 30, 18-28. doi: 10.5670/oceanog.2017.213

Johns, W. E., Baringer, M. O., Beal, L. M., Cunningham, S. A., Kanzow, T., Bryden, H. L., et al. (2011). Continuous array-based estimates of Atlantic Ocean heat transport at $26.5^{\circ}$ N. J. Clim. 24, 2429-2449. doi: 10.1175/2010JCLI3997.1

Johns, W. E., Beal, L. M., Baringer, M. O., Molina, J. R., Cunningham, S. A., Kanzow, T., et al. (2008). Variability of shallow and deep western boundary currents off the Bahamas during 2004-2005: results from the $26^{\circ} \mathrm{N}$ RAPIDMOC array. J. Phys. Oceanogr. 38, 605-623. doi: 10.1175/2007JPO3791.1

Johns, W. E., Kanzow, T., and Zantopp, R. (2005). Estimating ocean transports with dynamic height moorings: an application in the Atlantic Deep Western 
Boundary Current at $26^{\circ}$ N. Deep Sea Res. Part I 52, 1542-1567. doi: 10.1016/j. dsr.2005.02.002

Johnson, C. R., Banks, S. C., Barrett, N. S., Cazassus, F., Dunstan, P. K., Edgar, G. J., et al. (2011). Climate change cascades: shifts in oceanography, species' ranges and subtidal marine community dynamics in eastern Tasmania. J. Exp. Mar. Biol. Ecol. 400, 17-32. doi: 10.1016/j.jembe.2011.02.032

Johnson, G. C. (2001). The Pacific Ocean subtropical cell surface limb. Geophys. Res. Lett. 28, 1771-1774. doi: 10.1029/2000gl012723

Johnson, K. S., Plant, J. N., Coletti, L. J., Jannasch, H. W., Sakamoto, C. M., Riser, S. C., et al. (2017). Biogeochemical sensor performance in the SOCCOM profiling float array. J. Geophys. Res. 122, 6416-6436. doi: 10.1002/ 2017JC012838

Johnston, T. M. S., and Rudnick, D. L. (2015). Mixing estimates in the California Current System from sustained observations by underwater gliders. Deep Sea Res. II 112, 61-78. doi: 10.1016/j.dsr2.2014.03.009

Johnston, T. M., Rudnick, D. L., Alford, M. H., Pickering, A., and Simmons, H. L. (2013). Internal tidal energy fluxes in the South China Sea from density and velocity measurements by gliders. J. Geophys. Res. Oceans 118, 3939-3949. doi: 10.1002 /jgrc.20311

Junker, T., Mohrholz, V., Schmidt, M., Siegfried, L., and van der Plas, A. (2019). Coastal trapped wave propagation along the southwest African shelf as revealed by moored observations. J. Phys. Oceanogr. 49, 851-866. doi: 10.1175/JPO-D18-0046

Junker, T., Mohrholz, V., Siegfried, L., and van der Plas, A. (2017a). Seasonal to interannual variability of water mass characteristics and currents on the Namibian shelf. J. Mar. Syst. 165, 36-46. doi: 10.1016/j.jmarsys.2016.09.003

Junker, T., Mohrholz, V., Siegfried, L., van der Plas, A., Heene, T., and Beier, S. (2017b). Daily Means of Bottom Temperature and Bottom Oxygen Measurements on the Namibian Shelf at $18^{\circ} \mathrm{S}$. Warnemünde: Leibniz Institute for Baltic Sea Research, doi: 10.1594/PANGAEA.871251

Junker, T., Mohrholz, V., Siegfried, L., van der Plas, A., Heene, T., and Beier, S. (2017c). Daily Means of Horizontal Currents Measurements on the Namibian Shelf at $18^{\circ} \mathrm{S}$. Warnemünde: Leibniz Institute for Baltic Sea Research, doi: 10.1594/PANGAEA.871253

Junker, T., Mohrholz, V., Siegfried, L., van der Plas, A., Heene, T., Beier, S., et al. (2017d). Daily Means of Horizontal Currents Measurements on the Namibian Shelf at $20^{\circ} \mathrm{S}$. Warnemünde: Leibniz Institute for Baltic Sea Research, doi: 10.1594/PANGAEA.872098

Junker, T., Mohrholz, V., Siegfried, L., van der Plas, A., Heene, T., and Breier, S. (2017e). Daily Means of Bottom Temperature and Bottom Oxygen Measurements on the Namibian Shelf at $20^{\circ} \mathrm{S}$. Warnemünde: Leibniz Institute for Baltic Sea Research, doi: 10.1594/PANGAEA.872099

Juranek, L. W., Feely, R. A., Peterson, W. T., Alin, S. R., Hales, B., Lee, K., et al. (2009). A novel method for determination of aragonite saturation state on the continental shelf of central Oregon using multi-parameter relationships with hydrographic data. Geophys. Res. Lett. 36:L24601. doi: 10.1029/2009GL04 0778

Jury, M. R., Valentine, H. R., and Lutjeharms, J. R. (1993). Influence of the Agulhas Current on summer rainfall along the southeast coast of South Africa. J. Appl. Meteorol. 32, 1282-1287. doi: 10.1175/1520-0450(1993)032<1282:iotaco > 2.0.co; 2

Karstensen, J., Schütte, F., Pietri, A., Krahmann, G., Fiedler, B., Grundle, D., et al. (2017). Upwelling and isolation in oxygen-depleted anticyclonic modewater eddies and implications for nitrate cycling. Biogeosciences 14, 2167-2181. doi: 10.5194/bg-14-2167-2017

Kelly, K. A., Small, R. J., Samelson, R. M., Qiu, B., Joyce, T. M., Kwon, Y. O., et al. (2010). Western boundary currents and frontal air-sea interaction: Gulf Stream and Kuroshio Extension. J. Clim. 23, 5644-5667. doi: 10.1175/2010JCLI3346.1

Kerry, C., Powell, B., Roughan, M., and Oke, P. (2016). Development and evaluation of a high-resolution reanalysis of the East Australian Current region using the regional ocean modelling system (ROMS 3.4) and incremental strongconstraint 4-Dimensional variational (IS4D-Var) data assimilation. Geosci. Model. Dev. 9, 3779-3801. doi: 10.5194/gmd-9-3779-2016

Kerry, C., Roughan, M., and Powell, B. (2018). Observation impact in a regional reanalysis of the East Australian Current System. J. Geophys. Res. 123, 75117528. doi: $10.1029 / 2017 \mathrm{JC} 013685$

Kersalé, M., Lamont, T., Speich, S., Terre, T., Laxenaire, R., Roberts, M. J., et al. (2018). Moored observations of mesoscale features in the Cape Basin: characteristics and local impacts on water mass distributions. Ocean Sci. 14, 923-945. doi: 10.5194/os-14-923-2018

Kim, S. Y. (2010). Observations of submesoscale eddies using high-frequency radar-derived kinematic and dynamic quantities. Cont. Shelf Res. 30, 16391655. doi: $10.1016 /$ j.csr.2010.06.011

Kim, S. Y., and Kosro, P. M. (2013). Observations of near-inertial surface currents off Oregon: decorrelation time and length scales. Oceans 118, 3723-3736. doi: $10.1002 /$ jgrc. 20235

Kim, S. Y., Terrill, E. J., Cornuelle, B. D., Jones, B., Washburn, L., Moline, M. A., et al. (2011). Mapping the U.S. West Coast surface circulation: a multiyear analysis of high-frequency radar observations. J. Geophys. Res. 116:C03011. doi: 10.1029/2010JC006669

Klenz, T., Dengler, M., and Brandt, P. (2018). Seasonal variability of the Mauritania Current and hydrography at $18^{\circ}$ N. J. Geophys. Res. 123, 8122-8137. doi: 10. 1029/2018JC014264

Kolodziejczyk, N., Testor, P., Lazar, A., Echevin, V., Krahmann, G., Chaigneau, A., et al. (2018). Subsurface fine-scale patterns in an anticyclonic eddy off CapVert peninsula observed from glider measurements. J. Geophys. Res. Oceans 123, 6312-6329. doi: 10.1029/2018JC014135

Kono, T., and Kawasaki, Y. (1997). Results of CTD and mooring observations southeast of Hokkaido. 1. Annual verocity and transport variations in the Oyashio. Bull. Hokkaido Natl. Fish. Res. Inst. 61, 65-81.

Kopte, R., Brandt, P., Claus, M., Greatbatch, R. J., and Dengler, M. (2018). Role of equatorial basin-mode resonance for the seasonal variability of the Angola Current at $11^{\circ}$ S. J. Phys. Oceanogr. 48, 261-281. doi: 10.1175/JPO-D-17-0111.1

Kopte, R., Brandt, P., Dengler, M., Tchipalanga, P. C. M., Macuéria, M., and Ostrowski, M. (2017). The Angola Current: flow and hydrographic characteristics as observed at $11^{\circ} \mathrm{S}$. J. Geophys. Res. Oceans 122, 1177-1189. doi: 10.1002/2016JC012374

Koszalka, I., and LaCasce, J. H. (2010). Lagrangian analysis by clustering. Ocean Dyn. 60, 957-972. doi: 10.1007/s10236-010-0306-2

Krug, M., Swart, S., and Gula, J. (2017). Submesoscale cyclones in the Agulhas Current. Geophys. Res. Lett. 44, 346-354. doi: 10.1002/2016GL071006

Kuroda, H., Wagawa, T., Kakehi, S., Shimizu, Y., Kusaka, A., Okunishi, T., et al. (2017). Long-term mean and seasonal variation of altimetry-derived Oyashio transport across the A-line off the southeastern coast of Hokkaido. Jpn. Deep Sea Res. Part I 121, 95-109. doi: 10.1016/j.dsr.2016.12.006

Kuroda, H., Wagawa, T., Shimizu, Y., Ito, S., Kakehi, S., Okunishi, T., et al. (2015). Interdecadal decrease of the Oyashio transport on the continental slope off the southeastern coast of Hokkaido, Japan. J. Geophys. Res. Oceans 120, 2504-2522. doi: 10.1002/2014JC010402

LaCasce, J. H. (2008). Statistics from Lagrangian observations. Prog. Oceanogr. 77, 1-29. doi: 10.1016/j.pocean.2008.02.002

Landschützer, P., Gruber, N., Bakker, D. C. E., and Schuster, U. (2014). Recent variability of the global ocean carbon sink. Glob. Biogeochem. Cycles 28, 927949. doi: $10.1002 / 2014 \mathrm{~GB} 004853$

Large, W. G., and Danabasoglu, G. (2006). Attribution and impacts of upper-ocean biases in CCSM3. J. Clim. 19, 2325-2346. doi: 10.1175/JCLI3740.1

Larsen, J. C., and Sanford, T. B. (1985). Florida Current volume transports from voltage measurements. Science 227, 302-304. doi: 10.1126/science.227. 4684.302

Laurindo, L. C., Mariano, A., and Lumpkin, R. (2017). An improved near-surface velocity climatology for the global ocean from drifter observations. Deep Sea Res. I 124, 73-92. doi: 10.1016/j.dsr.2017.04.009

Leber, G. M., Beal, L. M., and Elipot, S. (2017). Wind and current forcing combine to drive strong upwelling in the Agulhas Current. J. Phys. Oceanogr. 47, 123-134. doi: 10.1175/JPO-D-16-0079.1

Lee, E. A., and Kim, S. Y. (2018). Regional variability and turbulent characteristics of the satellite-sensed submesoscale surface chlorophyll concentrations. J. Geopyhs. Res. 123, 4250-4279. doi: 10.1029/2017JC013732

Lee, T., and Fukumori, I. (2003). Interannual-to-decadal variations of tropicalsubtropical exchange in the Pacific Ocean: boundary versus interior pycnocline transports. J. Clim. 16, 4022-4042. doi: 10.1175/1520-0442(2003)016<4022: ivotei>2.0.co;2

Lengaigne, M., Hausmann, U., Madec, G., Menkes, C. E., Vialard, J., and Molines, J. M. (2012). Mechanisms controlling warm water volume interannual variations in the equatorial Pacific: diabatic versus adiabatic processes. Clim. Dyn. 38, 1031-1046. doi: 10.1007/s00382-011-1051-z 
Levine, N. M., Doney, S. C., Lima, I., Wanninkhof, R., Bates, N. R., and Feely, R. A. (2011). The impact of the North Atlantic Oscillation on the uptake and accumulation of anthropogenic $\mathrm{CO}_{2}$ by North Atlantic Ocean mode waters. Glob. Biogeochem. Cycles 25:GB3022. doi: 10.1029/2010GB003892

Liang, X., Spall, M., and Wunsch, C. (2017). Global ocean vertical velocity from a dynamically consistent ocean state estimate. J. Geophys. Res. 122, 8208-8224. doi: 10.1002/2017JC012985

Lien, R.-C., Ma, B., Cheng, Y.-H., Ho, C.-R., Qiu, B., Lee, C. M., et al. (2014). Modulation of Kuroshio transport by mesoscale eddies at the Luzon Strait entrance. J. Geophys. Res. Oceans 119, 2129-2142. doi: 10.1002/2013JC009548

Lien, R.-C., Ma, B., Lee, C. M., Sanford, T. B., Mensah, V., Centurioni, L. R., et al. (2015). The Kuroshio and Luzon Undercurrent east of Luzon Island. Oceanography 28, 54-63. doi: 10.5670/oceanog.2015.81

Lima, M. O., Cirano, M., Mata, M., Goes, M., Goni, G., and Baringer, M. O. (2016). An assessment of the Brazil Current baroclinic structure and variability near $22^{\circ} \mathrm{S}$ in distinct ocean forecasting and analysis systems. Ocean Dyn. 66, 893-916. doi: 10.1007/s10236-016-0959-6

Linder, C. A., and Gawarkiewicz, G. G. (1998). A climatology of the shelfbreak front in the Middle Atlantic Bight. J. Geophys. Res. 103, 18405-18423. doi: 10.1029/98JC01438

Lindstrom, E., Gunn, J., Fischer, A., McCurdy, A., and Glover, L. K. (2012). A Framework for Ocean Observing. By the Task Team for an Integrated Framework for Sustained Ocean Observing. Paris: UNESCO, doi: 10.5270/Ocean Obs09-FOO

Louw, D., van der Plas, A., Mohrholz, V., Wasmund, N., Junker, T., and Eggert, A. (2016). Seasonal and interannual phytoplankton dynamics and forcing mechanisms in the northern Benguela upwelling system. J. Mar. Syst. 157, 124-134. doi: 10.1016/j.jmarsys.2016.01.009

Lovechio, E., Gruber, N., and Münnich, M. (2018). Mesoscale contribution to the long-range offshore transport of organic carbon from the Canary Upwelling system to the open North Atlantic. Biogeosciences 15, 5061-5091. doi: 10.5194/ bg-15-5061-2018

Lowcher, C. F., Muglia, M., Bane, J. M., He, R., Gong, Y., Haines, S. M., et al. (2017). "Marine hydrokinetic energy in the Gulf Stream off North Carolina: an assessment using observations and ocean circulation models," in Marine Renewable Energy, eds Z. Yang and A. Copping (Cham: Springer), doi: 10.1007/ 978-3-319-53536-4_10

Lumpkin, R. (2003). Decomposition of surface drifter observations in the Atlantic Ocean. Geophys. Res. Lett. 30:1753. doi: 10.1029/2003GL017519

Lumpkin, R., and Garzoli, S. L. (2011). Interannual to decadal changes in the western South Atlantic's surface circulation. J. Geophys. Res. 116:C01014. doi: 10.1029/2010JC006285

Lumpkin, R., and Johnson, G. (2013). Global ocean surface velocities from drifters: mean, variance, El Niño-Southern Oscillation response, and seasonal cycle. J. Geophys. Res. 118, 2992-3006. doi: 10.1002/jgrc.20210

Lumpkin, R., and Pazos, M. C. (2007). "Measuring surface currents with surface velocity program drifters: the instrument, its data, and some recent results," in Lagrangian Analysis and Prediction of Coastal and Ocean Dynamics, eds A. Griffa, A. D. Kirwan, A. J. Mariano, T. Ozgokmen, and H. T. Rossby (Cambridge: Cambridge University Press), 39-67. doi: 10.1017/ cbo9780511535901.003

Lumpkin, R., Maximenko, N., and Pazos, M. (2012). Evaluating where and why drifters die. J. Atmos. Ocean. Technol. 29, 300-308. doi: 10.1175/jtech-d-1100100.1

Lumpkin, R., Özgökmen, T., and Centurioni, L. (2017). Advances in the application of surface drifters. Annu. Rev. Mar. Sci. 9, 59-81. doi: 10.1146/annurev-marine010816-060641

Lund, B., Haus, B. K., Horstmann, J., Graber, H. C., Carrasco, R., Laxague, N. J., et al. (2018). Near-surface current mapping by shipboard marine X-band radar: a validation. J. Atmos. Oceanic Technol. 35, 1077-1090. doi: 10.1175/JTECH-D17-0154.1

Lutjeharms, J. R. (2006). The Agulhas Current. Berlin: Springer.

Lynch, T. P., Morello, E. B., Evans, K., Richardson, A., Rochester, W., Steinberg, C. R., et al. (2014). IMOS national reference stations: a continental scale physical, chemical, biological coastal observing system. PLoS One 9:e113652. doi: 10.1371/journal.pone.0113652

Ma, X., Chang, P., Saravanan, R., Montuoro, R., Nakamura, H., Wu, D., et al. (2017). Importance of resolving Kuroshio front and eddy influence in simulating the North Pacific storm track. J. Clim. 30, 1861-1880. doi: 10.1175/ JCLI-D-16-0154.1

Machu, E., Capet, X., Estrade, P. A., Ndoye, S., Brajard, J., Baurand, F., et al. (2019). First evidence of anoxia and nitrogen loss in the southern Canary upwelling system. Geophys. Res. Lett. 46, 2619-2627. doi: 10.1029/2018GL079622

Mackey, D. J., O’Sullivan, J. E., and Watson, R. J. (2002). Iron in the western Pacific: a riverine or hydrothermal source for iron in the equatorial undercurrent. Deep Sea. Res. I 49, 877-893. doi: 10.1016/S0967-0637(01)00075-9

Majumder, S., and Schmid, C. (2018). A study of the variability in the Benguela Current volume transport. Ocean Sci. 14, 273-283. doi: 10.5194/os-14-2732018

Majumder, S., Goes, M., Polito, P. S., Lumpkin, R., Schmid, C., and Lopez, H. (2019). Propagating modes of variability and their impact on the western boundary current in the South Atlantic. J. Geophys. Res. Oceans 124, 3168-3185. doi: 10.1029/2018JC014812

Mansfield, K. L., Mendilaharsu, M. L., Putman, N. F., dei Marcovaldi, M. A., Sacco, A. E., Lopez, G., et al. (2017). First satellite tracks of South Atlantic sea turtle 'lost years': seasonal variation in trans-equatorial movement. Proc. Biol. Sci. 284:20171730. doi: 10.1098/rspb.2017.1730

Mantovanelli, A., Keating, S., Wyatt, L., Roughan, M., and Schaeffer, A. (2017). Lagrangian and Eulerian characterization of two counter rotating submesoscale eddies in a western boundary current. J. Geophys. Res. Oceans 122, 4902-4921. doi: 10.1002/2016JC011968

Marra, J., Houghton, R. W., and Garside, C. (1990). Phytoplankton growth at the shelf-break front in the Middle Atlantic Bight. J. Mar. Res. 48, 851-868. doi: 10.1357/002224090784988665

Marzeion, B., Cogley, J. G., Richter, K., and Parkes, D. (2014). Attribution of global glacier mass loss to anthropogenic and natural causes. Science 345, 919-921. doi: 10.1126/science. 1254702

Mata, M. M., Cirano, M., van Caspel, M. R., Fonteles, C. S., Goni, G., and Baringer, M. (2012). Observations of Brazil Current baroclinic transport near $22^{\circ} \mathrm{S}$ : variability from the AX97 XBT transect. CLIVAR Exchanges 58, 5-10. doi: 10.1007/s10236-016-0959-6

Matano, R. P., and Palma, E. D. (2008). On the upwelling of downwelling currents. J. Phys. Oceanogr. 38, 2482-2500. doi: 10.1175/2008jpo3783.1

Matano, R. P., Combes, V., Piola, A. R., Guerrero, R. A., Palma, E. D., Strub, P. T., et al. (2014). The salinity signature of the cross-shelf exchanges in the Southwestern Atlantic Ocean: numerical simulations. J. Geophys. Res. Oceans 119, 7949-7968. doi: 10.1002/2014JC010116

Maximenko, N., Niiler, P., Centurioni, L., Rio, M.-H., Melnichenko, O., Chambers, D., et al. (2009). Mean dynamic topography of the ocean derived from satellite and drifting buoy data using three different techniques. J. Atmos. Ocean. Technol. 26, 1910-1919. doi: 10.1175/2009JTECHO672.1

Mazzini, P. L. F., Barth, J. A., Shearman, R. K., and Erofeev, A. (2014). Buoyancydriven coastal currents off the Oregon coast during fall and winter. J. Phys. Oceanogr. 44, 2854-2876. doi: 10.1175/JPO-D-14-0012.1

McClatchie, S. (2014). Regional Fisheries Oceanography of the California Current System: The CalCOFI Program. Berlin: Springer, doi: 10.1007/978-94-0077223-6

McClatchie, S., Thompson, A. R., Alin, S. R., Siedlecki, S., Watson, W., and Bograd, S. J. (2016). The influence of Pacific Equatorial Water on fish diversity in the southern California Current System. J. Geophys. Res. Oceans 121, 6121-6136. doi: 10.1002/2016JC011672

Meinen, C. S., and Watts, D. R. (2000). Vertical structure and transport on a transect across the North Atlantic Current near $42^{\circ} \mathrm{N}$ : time series and mean. J. Geophys. Res. 105, 21869-21891. doi: 10.1029/2000JC900097

Meinen, C. S., Baringer, M. O., and Garcia, R. F. (2010). Florida Current transport variability: an analysis of annual and longer-period signals. Deep Sea Res. I 57, 835-846. doi: 10.1016/j.dsr.2010.04.001

Meinen, C. S., Garzoli, S. L., Perez, R. C., Campos, E., Piola, A. R., Chidichimo, M. P., et al. (2017). Characteristics and causes of Deep Western Boundary Current transport variability at $34.5^{\circ} \mathrm{S}$ during 2009-2014. Ocean Sci. 13, 175194. doi: 10.5194/os-13-175-2017

Meinen, C. S., Johns, W. E., Garzoli, S. L., van Sebille, E., Rayner, D., Kanzow, T., et al. (2013). Variability of the Deep Western Boundary Current at $26.5 \mathrm{~N}$ during 2004-2009. Deep Sea Res. II 85, 154-168. doi: 10.1016/j.dsr2.2012.07.036

Meinen, C. S., Speich, S., Piola, A. R., Ansorge, I., Campos, E., Kersale, M., et al. (2018). Meridional overturning circulation transport variability at $34.5^{\circ} \mathrm{S}$ 
during 2009-2017: baroclinic and barotropic flows and the dueling influence of the boundaries. Geophys. Res. Lett. 45, 4180-4188. doi: 10.1029/2018GL07 7408

Menna, M., Faye, S., Poulain, P.-M., Centurioni, L., Lazar, A., Gaye, A., et al. (2016). Upwelling features of the coast of north-western Africa in 2009-2013. Boll. Geofis. Teor. Appl. 57, 71-86. doi: 10.4430/bgta0164

Messié, M., and Chavez, F. P. (2015). Seasonal regulation of primary production in eastern boundary upwelling systems. Prog. Oceanogr. 134, 1-18. doi: 10.1016/j. pocean.2014.10.011

Middleton, J. F., and Bye, J. T. (2007). A review of the shelf-slope circulation along Australia's southern shelves: Cape Leeuwin to Portland. Prog. Oceanogr. 75, 1-41. doi: 10.1016/j.pocean.2007.07.001

Middleton, J. F., and Cirano, M. (2002). A boundary current along Australia's southern shelves: the Flinders Current. J. Geophys. Res. 107:3129. doi: 10.1029/ 2000JC000701

Mihanoviæ, H., Pattiaratchi, C., and Verspecht, F. (2016). Diurnal sea breezes force near-inertial waves along Rottnest continental shelf, southwestern Australia. J. Phys. Oceanogr. 46, 3487-3508. doi: 10.1175/JPO-D-16-0022.1

Mohrholz, V., Bartholomae, C. H., van der Plas, A. K., and Lass, H. U. (2008). The seasonal variability of the northern Benguela undercurrent and its relation to the oxygen budget on the shelf. Cont. Shelf Res. 28, 424-441. doi: 10.1016/j.csr. 2007.10.001

Moloney, C. L., Van Der Lingen, C. D., Hutchings, L., and Field, J. G. (2004). Contributions of the Benguela ecology programme to pelagic fisheries management in South Africa. Afr. J. Mar. Sci. 26, 37-51. doi: 10.2989/ 18142320409504048

Monteiro, P. M. S., and van der Plas, A. K. (2006). "Low oxygen water (LOW) variability in the Benguela system: key processes and forcing scales relevant to forecasting," in Benguela: Predicting a Large Marine Ecosystem, eds V. Shannon, et al. (Netherlands: ElsevierAmsterdam), 71-90. doi: 10.1016/s1570-0461(06) 80010-8

Monteiro, P. M. S., van der Plas, A. K., Mélice, J.-L., and Florenchie, P. (2008). Interannual hypoxia variability in a coastal upwelling system: ocean-shelf exchange, climate and ecosystem-state implications. Deep Sea Res. I 55, 435450. doi: 10.1016/j.dsr.2007.12.010

Mosquera-Vásquez, K., Dewitte, B., Illig, S., Takahashi, K., and Garric, G. (2013). The 2002/2003 El Niño: equatorial waves sequence and their impact on sea surface temperature. J. Geophys. Res. Oceans 118, 346-357.

Nagai, T., and Clayton, S. (2017). Nutrient interleaving below the mixed layer of the Kuroshio Extension front. Ocean Dyn. 67, 1027-1046. doi: 10.1007/s10236017-1070-3

Nagano, A., Kizu, S., Hanawa, K., and Roemmich, D. (2016). Heat transport variation due to change of North Pacific subtropical gyre interior flow during 1993-2012. Ocean Dyn. 66, 1637-1649. doi: 10.1007/s10236-016-1007-2

Nakamura, M. (2012). Impacts of SST anomalies in the Agulhas Current System on the regional climate variability. J. Clim. 25, 1213-1229. doi: 10.1175/JCLID-11-00088.1

Nakano, H., Tsujino, H., Yasuda, M., Hirabara, T., Motoi, T., Ishii, M., et al. (2011). Uptake mechanisms of anthropogenic $\mathrm{CO}_{2}$ in the Kuroshio Extension region in an ocean general circulation model. J. Oceanogr. 67, 765-783. doi: 10.1007/s10872-011-0075-7

Nakano, T., Kitamura, T., Sugimoto, S., Suga, T., and Kamachi, M. (2015). Long-term variations of North Pacific Tropical Water along the $137^{\circ} \mathrm{E}$ repeat hydrographic section. J. Oceanogr. 71, 229-238. doi: 10.1007/s10872-0150279-3

Nam, S., Kim, H. J., and Send, U. (2011). Amplification of hypoxic and acidic events by La Niña conditions on the continental shelf off California. Geophys. Res. Lett. 38:L22602. doi: 10.1029/2011g1049549

Nguyen, L. T., and Molinari, J. (2012). Rapid intensification of a sheared, fastmoving hurricane over the Gulf Stream. Mon. Weather Rev. 140, 3361-3378. doi: 10.1175/MWR-D-11-00293.1

Niewiadomska, K., Claustre, H., Prieur, L., and d'Ortenzio, F. (2008). Submesoscale physical-biogeochemical coupling across the Ligurian Current (northwestern Mediterranean) using a bio-optical glider. Limnol. Oceanogr. 53, 2210-2225. doi: 10.4319/lo.2008.53.5_part_2.2210

Niiler, P. P. (2001). "The world ocean surface circulation," in Ocean Circulation and Climate, eds G. Siedler, J. Church, and J. Gould (Cambridge, MA: Academic Press), 193-204. doi: 10.1016/s0074-6142(01)80119-4
Niiler, P. P., Maximenko, N. A., Panteleev, G. G., Yamagata, T., and Olson, D. B. (2003). Near-surface dynamical structure of the Kuroshio Extension. J. Geophys. Res. 108:3193. doi: 10.1029/2002JC001461

Niiler, P. P., Sybrandy, A., Bi, K., Poulain, P. M., and Bitterman, D. (1995). Measurements of the water-following capability of holey-sock and TRISTAR drifters. Deep Sea Res. I 42, 1951-1964. doi: 10.1016/0967-0637(95)00076-3

Nkwinkwa Njouodo, A. S., Koseki, S., Keenlyside, N., and Rouault, M. (2018). Atmospheric signature of the Agulhas Current. Geophys. Res. Lett. 45, 51855193. doi: 10.1029/2018GL077042

Nowald, N., Iversen, M. H., Fischer, G., Ratmeyer, V., and Wefer, G. (2015). Time series of in-situ particle properties and sediment trap fluxes in the coastal upwelling filament off Cape Blanc, Mauritania. Prog. Oceanogr. 137, 1-11. doi: 10.1016/j.pocean.2014.12.015

O'Reilly, C. H., and Czaja, A. (2015). The response of the Pacific storm track and atmospheric circulation to Kuroshio Extension variability. Q. J. R. Meteorol. Soc. 141, 52-66. doi: 10.1002/qj.2334

O'Reilly, C. H., Minobe, S., and Kuwano-Yoshida, A. (2016). The influence of the Gulf Stream on wintertime European blocking. Clim. Dyn. 47, 1545-1567. doi: 10.1007/s00382-015-2919-0

Oettli, P., Morioka, Y., and Yamagata, T. (2016). A regional climate mode discovered in the North Atlantic: Dakar Niño/Niña. Sci. Rep. 6:18782. doi: $10.1038 /$ srep 18782

Ohman, M. D., Rudnick, D. L., Chekalyuk, A., Davis, R. E., Feely, R. A., Kahru, M., et al. (2013). Autonomous ocean measurements in the California Current Ecosystem. Oceanography 26, 18-25. doi: 10.5670/oceanog.2013.41

Oka, E., and Kawabe, M. (2003). Dynamic structure of the Kuroshio south of Kyushu in relation to the kuroshio path variations. J. Oceanogr. 59, 595-608. doi: 10.1023/B:JOCE.0000009589.28241.93

Oka, E., Ishii, M., Nakano, T., Suga, T., Kouketsu, S., Miyamoto, M., et al. (2018). Fifty years of the 137E repeat hydrographic section in the western North Pacific Ocean. J. Oceanogr. 74, 115-145. doi: 10.1007/s10872-017-0461-x

Oka, E., Qiu, B., Takatani, Y., Enyo, K., Sasano, D., Kosugi, N., et al. (2015). Decadal variability of Subtropical Mode Water subduction and its impact on biogeochemistry. J. Oceanogr. 71, 389-400. doi: 10.1007/s10872-015-0300-x

Oliveira, L. R., Piola, A. R., Mata, M. M., and Soares, I. D. (2009). Brazil Current surface circulation and energetics observed from drifting buoys. J. Geophys. Res. 114:C10006. doi: 10.1029/2008JC004900

Oliver, E. C. J., O’Kane, T. J., and Holbrook, N. J. (2015). Projected changes to Tasman Sea eddies in a future climate. Oceans 120, 7150-7165. doi: 10.1002/ 2015JC010993

Oliver, E. C., Benthuysen, J. A., Bindoff, N. L., Hobday, A. J., Holbrook, N. J., Mundy, C. N., et al. (2017). The unprecedented 2015/16 Tasman Sea marine heatwave. Nat. Commun. 8:16101. doi: 10.1038/ncomms16101

Olson, D., Podesta, G. P., Evans, R. H., and Brown, O. (1988). Temporal variations in the separation of Brazil and Malvinas Currents. Deep Sea Res. 35, 1971-1990. doi: 10.1016/0198-0149(88)90120-3

Paduan, J. D., and Washburn, L. (2013). High-frequency radar observations of ocean surface currents. Annu. Rev. Mar. Sci. 5, 115-136. doi: 10.1146/annurevmarine-121211-172315

Palacz, A. P., Pearlman, J., Simmons, S., Hill, K., Miloslavich, P., Telszewski, M., et al. (2017). Report of the Workshop on the Implementation of Multidisciplinary Sustained Ocean Observations (IMSOO). Global Ocean Observing System (GOOS) Report No. 223. Available at: http://www.goosocean.org/imsooreport (accessed July 23, 2019).

Palevsky, H. I., and Nicholson, D. P. (2018). The North Atlantic biological pump: insights from the Ocean Observatories Initiative Irminger Sea array. Oceanography 31, 42-49. doi: 10.5670/oceanog.2018.108

Palevsky, H. I., and Quay, P. D. (2017). Influence of biological carbon export on ocean carbon uptake over the annual cycle across the North Pacific Ocean. Glob. Biogeochem. Cycles 31, 1-15. doi: 10.1002/2016GB005527

Palevsky, H. I., Quay, P. D., Lockwood, D. E., and Nicholson, D. P. (2016). The annual cycle of gross primary production, net community production, and export efficiency across the North Pacific Ocean. Glob. Biogeochem. Cycles 30, 361-380. doi: 10.1002/2015GB005318

Palter, J. B., and Lozier, M. S. (2008). On the source of Gulf Stream nutrients. J. Geophys. Res. 113:C06018. doi: 10.1029/2007jc004611

Paniagua, G. F., Saraceno, M., Piola, A. R., Guerrero, R., Provost, C., Ferrari, R., et al. (2018). Malvinas Current at $40^{\circ} \mathrm{S}-41^{\circ} \mathrm{S}$ : first assessment of temperature 
and salinity temporal variability. J. Geophys. Res. Oceans 123, 5323-5340. doi: 10.1029/2017JC013666

Park, J., and Sweet, W. (2015). Accelerated sea level rise and Florida Current transport. Ocean Sci. 11, 607-615. doi: 10.5194/os-11-607-2015

Parks, A. B., Shay, L. K., Johns, W. E., Martinez-Pedraja, J., and Gurgel, K. W. (2009). HF radar observations of small-scale surface current variability in the Straits of Florida. J. Geophys. Res. 114:C08002. doi: 10.1029/2008JC005025

Parrilla, G., Neuer, S., and Le Traon, P.-Y. (2002). Topical studies in oceanography: Canary Islands Azores Gibraltar Observations (CANIGO). Volume 1: studies in the northern Canary Islands basin. Deep Sea Res. II 49, 3409-3413. doi: 10.1016/s0967-0645(02)00104-2

Pattiaratchi, C., Hollings, B., Woo, M., and Welhena, T. (2011). Dense shelf water formation along the south-west Australian inner shelf. Geophys. Res. Lett. 38:L10609. doi: 10.1029/2011GL046816

Paulmier, A., and Ruiz-Pino, D. (2009). Oxygen minimum zones (OMZs) in the modern ocean. Prog. Oceanogr. 80, 113-128. doi: 10.1016/j.pocean.2008.08.001

Pearce, A., and Feng, M. (2013). The rise and fall of the "marine heat wave" off western Australia during the summer of 2010/11. J. Mar. Syst. 111-112, 139-156. doi: 10.1016/j.jmarsys.2012.10.009

Pegliasco, C., Chaigneau, A., and Morrow, R. (2015). Main eddy vertical structures observed in the four major eastern boundary upwelling systems. Oceans 120, 6008-6033. doi: 10.1002/2015JC010950

Pelegrí, J. L., and Csanady, G. T. (1991). Nutrient transport and mixing in the Gulf Stream. J. Geophys. Res. 96, 2577-2583. doi: 10.1029/90JC02535

Pelegrí, J. L., Csanady, G. T., and Martins, A. (1996). The North Atlantic nutrient stream. J. Oceanogr. 52, 275-299. doi: 10.1007/BF02235924

Pelland, N. A., Eriksen, C. C., and Lee, C. M. (2013). Subthermocline eddies over the Washington continental slope as observed by Seagliders, 2003-09. J. Phys. Oceanogr. 43, 2025-2053. doi: 10.1175/jpo-d-12-086.1

Perry, M. J., Sackmann, B. S., Eriksen, C. C., and Lee, C. M. (2008). Seaglider observations of blooms and subsurface chlorophyll maxima off the Washington coast. Limnol. Oceanogr. 53, 2169-2179. doi: 10.4319/lo.2008.53.5_part_2. 2169

Pickart, R. S., and Smethie, W. M. (1993). How does the Deep Western Boundary Current cross the Gulf Stream? J. Phys. Oceanogr. 23, 2602-2616. doi: 10.1038/ s41598-018-22758-z

Pickart, R. S., and Watts, D. R. (1990). Deep western boundary current variability at Cape Hatteras. J. Mar. Res. 48, 765-791. doi: 10.1357/002224090784988674

Pietri, A., Echevin, V., Testor, P., Chaigneau, A., Mortier, L., Grados, C., et al. (2014). Impact of a coastal-trapped wave on the near-coastal circulation of the Peru upwelling system from glider data. Oceans 119, 2109-2120. doi: 10.1002/ 2013JC009270

Pietri, A., Testor, P., Echevin, V., Chaigneau, A., Mortier, L., Eldin, G., et al. (2013). Finescale vertical structure of the upwelling system off southern Peru as observed from glider data. J. Phys. Oceanogr. 43, 631-646. doi: 10.1175/JPOD-12-035.1

Pitcher, G. C., and Probyn, T. A. (2011). Anoxia in southern Benguela during the autumn of 2009 and its linkage to a bloom of the dinoflagellate Ceratium balechii. Harmful Algae 11, 23-32. doi: 10.1016/j.hal.2011.07.001

Pitcher, G. C., Probyn, T. A., du Randt, A., Lucas, A. J., Bernard, S., Evers-King, H., et al. (2014). Dynamics of oxygen depletion in the nearshore of a coastal embayment of the southern Benguela upwelling system. J. Geophys. Res. Oceans 119, 2183-2200. doi: 10.1002/2013JC009443

Pizarro, O., Ramírez, N., Castillo, M. I., Cifuentes, U., Rojas, W., and Pizarro-Koch, M. (2016). Underwater glider observations in the oxygen minimum zone off central Chile. Bull. Am. Meteor. Soc. 97, 1783-1789. doi: 10.1175/BAMS-D-1400040.1

Polo, I., Lazar, A., Rodriguez-Fonseca, B., and Arnault, S. (2008). Oceanic Kelvin waves and tropical Atlantic intraseasonal variability: 1. Kelvin wave characterization. J. Geophys. Res. 113:C07009. doi: 10.1029/2007JC004495

Pontes, G. M., Sen Gupta, A., and Taschetto, A. S. (2016). Projected changes to South Atlantic boundary currents and confluence region in the CMIP5 models: the role of wind and deep ocean changes. Environ. Res. Lett. 11:094013. doi: 10.1088/1748-9326/11/9/094013

Poulain, P. M., and Niiler, P. P. (1989). Statistical-analysis of the surface circulation in the California Current System using satellite-tracked drifters. J. Phys. Oceanogr. 19, 1588-1603. doi: 10.1175/1520-0485(1989)019<1588:saotsc $>$ 2.0.co;2
Probyn, T. A., Mitchellinnes, B. A., Brown, P. C., Hutchings, L., and Carter, R. A. (1994). Review of primary production and related processes on the Agulhas Bank. S. Afr. J. Sci. 90, 166-173.

Qiu, B., and Chen, S. (2005). Variability of the kuroshio extension jet, recirculation gyre, and mesoscale eddies on decadal time scales. J. Phys. Oceanogr. 35, 2090-2103. doi: 10.1175/JPO2807.1

Qiu, B., and Chen, S. (2010). Interannual-to-decadal variability in the bifurcation of the North Equatorial Current off the Philippines. J. Phys. Oceanogr. 40, 2525-2538. doi: 10.1175/2010JPO4462.1

Qiu, B., Chen, S., Schneider, N., and Taguchi, B. (2014). A coupled decadal prediction of the dynamic state of the Kuroshio Extension system. J. Clim. 27, 1751-1764. doi: 10.1175/JCLI-D-13-00318.1

Rainville, L., Lee, C. M., Rudnick, D. L., and Yang, K.-C. (2013). Propagation of internal tides generated near Luzon Strait: observations from autonomous gliders. J. Geophys. Res. 118, 4125-4138. doi: 10.1002/jgrc.20293

Reum, J. C. P., Alin, S. R., Harvey, C. J., Bednaršek, N., Evans, W., Feely, R. A., et al. (2016). Interpretation and design of ocean acidification experiments in upwelling systems in the context of carbonate chemistry co-variation with temperature and oxygen. ICES J. Mar. Sci. 73, 582-595. doi: 10.1093/icesjms/ fsu231

Reum, J. C., Alin, S. R., Feely, R. A., Newton, J., Warner, M., and McElhany, P. (2014). Seasonal carbonate chemistry covariation with temperature, oxygen, and salinity in a fjord estuary: implications for the design of ocean acidification experiments. PLoS One 9:e89619. doi: 10.1371/journal.pone.0089619

Révelard, A., Frankignoul, C., Sennéchael, N., Kwon, Y. O., and Qiu, B. (2016). Influence of the decadal variability of the kuroshio extension on the atmospheric circulation in the cold season. J. Clim. 29, 2123-2144. doi: 10.1175/ JCLI-D-15-0511.1

Richardson, P. L. (2007). Agulhas leakage into the Atlantic estimated with subsurface floats and surface drifters. Deep Sea Res. I 54, 1361-1389. doi: 10. 1016/j.dsr.2007.04.010

Richter, I. (2015). Climate model biases in the eastern tropical oceans: causes, impacts and ways forward. WIREs Clim. Chang 6, 345-358. doi: 10.1002/ wcc. 338

Ridgway, K. R., and Condie, S. A. (2004). The 5500-km-long boundary flow off western and southern Australia. J. Geophys. Res. 109:C04017. doi: 10.1029/ 2003JC001921

Ridgway, K. R., and Godfrey, J. S. (2015). The source of the Leeuwin Current seasonality. J. Geophys. Res. 120, 6843-6864. doi: 10.1002/2015JC011049

Rio, M. H., and Santoleri, R. (2018). Improved global surface currents from the merging of altimetry and Sea surface temperature data. Remote Sens. Environ. 216, 770-785. doi: 10.1016/j.rse.2018.06.003

Rio, M.-H., Mulet, S., and Picot, N. (2014). Beyond GOCE for the ocean circulation estimate: synergetic use of altimetry, gravimetry, and in situ data provides new insight into geostrophic and Ekman currents. Geophys. Res. Lett. 41, 8918-8925. doi: 10.1002/2014GL061773

Riser, S. C., Freeland, H. J., Roemmich, D., Wijffels, S., Troisi, A., Belbéoch, M., et al. (2016). Fifteen years of ocean observations with the global Argo array. Nat. Clim. Change 6, 145-153. doi: 10.1038/nclimate2872

Rodgers, K. B., Sarmiento, J. L., Crevoisier, C., de Boyer Montegut, C., Metzl, N., and Aumont, O. (2008). A wintertime uptake window for anthropogenic $\mathrm{CO}_{2}$ in the North Pacific. Glob. Biogeochem. Cycles 22:GB2020. doi: 10.1029/ 2006GB002920

Rodrigues, R. R., Rothstein, L. M., and Wimbush, M. (2007). Seasonal variability of the South Equatorial Current bifurcation in the Atlantic Ocean: a numerical study. J. Phys. Oceanogr. 37, 16-30. doi: 10.1175/JPO2983.1

Roemmich, D., Alford, M. H., Claustre, H., Johnson, K. S, King, B., Moum, J., et al. (2019). On the future of Argo: A global, full-depth, multi-disciplinary array. Front. Mar. Sci. 6:439. doi: 10.3389/fmars.2019. 00439

Roemmich, D., Boehme, L., Claustre, H., Freeland, H., Fukasawa, M., Goni, G., et al. (2010). "Integrating the ocean observing system: mobile platforms," in Proceedings of OceanObs'09: Sustained Ocean Observations and Information for Society, eds J. Hall, D. E. Harrison, and D. Stammer (Venice: ESA Publication WPP-306), 21-25. doi: 10.5270/OceanObs09

Rossby, H. T., Flagg, C. N., and Donohue, K. (2010). On the variability of Gulf Stream transport from seasonal to decadal timescales. J. Mar. Res. 68, 503-522. doi: $10.1357 / 002224010794657128$ 
Rossby, T., Flagg, C. N., Donohue, K., Sanchez-Franks, A., and Lillibridge, J. (2014). On the long-term stability of Gulf Stream transport based on 20 years of direct measurements. Geophys. Res. Lett. 41, 114-120. doi: 10.1002/2013GL05 8636

Rouault, M., Reason, C. J. C., Lutjeharms, J. R. E., and Beljaars, A. C. M. (2003). Underestimation of latent and sensible heat fluxes above the Agulhas Current in NCEP and ECMWF analyses. J. Clim. 16, 776-782. doi: 10.1175/15200442(2003)016<0776:uolash>2.0.co;2

Roughan, M., and Morris, B. D. (2011). "Using high-resolution ocean timeseries data to give context to long term hydrographic sampling off Port Hacking, NSW, Australia," in Proceedings of the Oceans'11 MTS/IEEE Kona, Waikoloa, HI, doi: 10.23919/OCEANS.2011.6107032

Roughan, M., Schaeffer, A., and Kioroglou, S. (2013). "Assessing the design of the NSW-IMOS Moored Observation Array from 2008-2013: recommendations for the future," in Proceedinds of the 2013 OCEANS -San Diego, San Diego, CA, doi: 10.23919/OCEANS.2013.6741092

Roughan, M., Schaeffer, A., and Suthers, I. M. (2015). Sustained ocean observing along the coast of Southeastern Australia: NSW-IMOS 2007-2014. Coast. Ocean Observing Syst. 2015, 76-98. doi: 10.1016/B978-0-12-802022-7.00006-7

Rudnick, D. L. (2017). Data from: Spray Underwater Glider Campaign in Gulf of Mexico. La Jolla, CA: Instrument Development Group, Scripps Institution of Oceanography, doi: 10.21238/s8SPRAY0420

Rudnick, D. L. (2016a). Data from: California Underwater Glider Network. La Jolla, CA: Instrument Development Group, Scripps Institution of Oceanography, doi: 10.21238/s8SPRAY1618

Rudnick, D. L. (2016b). Ocean research enabled by underwater gliders. Annu. Rev. Mar. Sci. 8, 519-541. doi: 10.1146/annurev-marine-122414-033913

Rudnick, D. L., and Cole, S. T. (2011). On sampling the ocean using underwater gliders. J. Geophys. Res. 116:C08010. doi: 10.1029/2010JC006849

Rudnick, D. L., Gopalakrishnan, G., and Cornuelle, B. D. (2015a). Cyclonic eddies in the Gulf of Mexico: observations by underwater gliders and simulations by numerical model. J. Phys. Oceanogr. 45, 313-326. doi: 10.1175/JPO-D-140138.1

Rudnick, D. L., Jan, S., and Lee, C. M. (2015b). A new look at circulation in the western North Pacific. Oceanography 28, 16-23. doi: 10.5670/oceanog.2015.77

Rudnick, D. L., Jan, S., Centurioni, L., Lee, C., Lien, R.-C., Wang, J., et al. (2011). Seasonal and mesoscale variability of the Kuroshio near its origin. Oceanography 24, 52-63. doi: 10.5670/oceanog.2011.94

Rudnick, D. L., Johnston, T. M., and Sherman, J. T. (2013). High-frequency internal waves near the Luzon Strait observed by underwater gliders. J. Geophys. Res. Oceans 118, 774-784. doi: 10.1002/jgrc.20083

Rudnick, D. L., Zaba, K. D., Todd, R. E., and Davis, R. E. (2017). A climatology of the California Current System from a network of underwater gliders. Prog. Oceanogr. 154, 64-106. doi: 10.1016/j.pocean.2017.03.002

Rühs, S., Getzlaff, K., Durgadoo, J. V., Biastoch, A., and Böning, C. W. (2015). On the suitability of North Brazil current transport estimates for monitoring basin-scale AMOC changes. Geophys. Res. Lett. 42, 8072-8080. doi: 10.1002/ 2015GL065695

Ryan, J. P., Ueki, I., Chao, Y., Zhang, H., Polito, P. S., and Chavez, F. P. (2006). Western Pacific modulation of large phytoplankton blooms in the central and eastern equatorial Pacific. J. Geophys. Res. 111:G02013. doi: 10.1029/ 2005JG000084

Rypina, I. I., Llopiz, J. K., Pratt, L. M., and Lozier, M. S. (2014). Dispersal pathways of American eel larvae from the Sargasso Sea. Limnol. Oceanogr. 59, 1704-1714. doi: 10.4319/lo.2014.59.5.1704

Saba, V. S., Griffies, S. M., Anderson, W. G., Winton, M., Alexander, M. A., Delworth, T. L., et al. (2016). Enhanced warming of the Northwest Atlantic Ocean under climate change. J. Geophys. Res. 121, 118-132. doi: 10.1002/ 2015JC011346

Saraceno, M., Guerrero, R., Piola, A., Provost, C., Perault, F., Ferrari, R., et al. (2017). Malvinas Current 2014-2015: Mooring Velocities. France: SEANOE, doi: $10.17882 / 51492$

Schaeffer, A., Roughan, M., Jones, E. M., and White, D. (2016). Physical and biogeochemical spatial scales of variability in the East Australian Current separation from shelf glider measurements. Biogeosciences 13, 1967-1975. doi: 10.5194/bg-13-1967-2016

Schaeffer, A. M., Roughan, T., Austin, J. D., Everett, D., Griffin, B., Hollings, E., et al. (2016). Mean hydrography on the continental shelf from 26 repeat glider deployments along Southeastern Australia. Sci. Data 3:160070. doi: 10.1038/ sdata.2016.70

Schaeffer, A., and Roughan, M. (2015). Influence of a western boundary current on shelf dynamics and upwelling from repeat glider deployments. Geophys. Res. Lett. 42, 121-128. doi: 10.1002/2014GL062260

Schaeffer, A., and Roughan, M. (2017). Subsurface intensification of marine heatwaves off southeastern Australia: the role of stratification and local winds. Geophys. Res. Lett. 44, 5025-5033. doi: 10.1002/2017GL073714

Schaeffer, A., Gramoulle, A., Roughan, M., and Mantovanelli, A. (2017). Characterizing frontal eddies along the East Australian Current from HF radar observations. J. Geophys. Res. 122, 3964-3980. doi: 10.1002/2016JC012171

Schaeffer, A., Roughan, M., and Morris, B. (2013). Cross-shelf dynamics in a western boundary current. Implications for upwelling. J. Phys. Oceanogr. 43, 1042-1059. doi: 10.1175/JPO-D-12-0177.1

Schaeffer, A., Roughan, M., and Morris, B. (2014). Corrigendum. J. Phys. Oceanogr. 44, 2812-2813. doi: 10.1175/JPO-D-14-0091.1

Schmid, C., and Majumder, S. (2018). Transport variability of the Brazil Current from observations and a data assimilation model. Ocean Sci. 14, 417-436. doi: 10.5194/os014-417-2018

Schneider, W., Donoso, D., Garcés-Vargas, J., and Escribano, R. (2016). Watercolumn cooling and sea surface salinity increase in the upwelling region off central-south Chile driven by a poleward displacement of the South Pacific. Prog. Oceanogr. 141, 38-58. doi: 10.1016/j.pocean.2016.11.004

Schönau, M. C., and Rudnick, D. L. (2017). Mindanao Current and Undercurrent: thermohaline structure and transport from repeat glider observations. J. Phys. Oceanogr. 47, 2055-2075. doi: 10.1175/JPO-D-16-0274.1

Schönau, M. C., Rudnick, D. L., Cerovecki, I., Gopalakrishnan, G., Cornuelle, B. D., McClean, J. L., et al. (2015). The Mindanao Current: mean structure and connectivity. Oceanography 28, 34-45. doi: 10.5670/oceanog.2015.79

Schott, F. A., Fischer, J., and Stramma, L. (1998). Transports and pathways of the upper-layer circulation in the western tropical Atlantic. J. Phys. Oceanogr. 28, 1904-1928. doi: 10.1175/1520-0485(1998)028<1904:tapotu >2.0.co;2

Schott, F., Dengler, M., Zantopp, R. J., Stramma, L., Fischer, J., and Brandt, P. (2005). The shallow and deep western boundary circulation of the South Atlantic at $5^{\circ}-11^{\circ}$ S. J. Phys. Oceanogr. 35, 2031-2053. doi: 10.1175/JPO 2813.1

Schott, F., Xie, S.-P., and McCreary, J. P. (2009). Indian Ocean circulation and climate variability. Rev. Geophys. 47:RG1002. doi: 10.1029/2007RG000245

Sen Gupta, A., Ganachaud, A., McGregor, S., Brown, J. N., and Muir, L. (2012). Drivers of the projected changes to the Pacific Ocean equatorial circulation. Geophys. Res. Lett. 39:L09605. doi: 10.1029/2012GL051447

Send, U. (2018). Data from: Spray Glider Data in Support of Mooring Observations from the CORC Project in the California Current Starting 2007. La Jolla, CA: Instrument Development Group, Scripps Institution of Oceanography, doi: 10.21238/s8SPRAY8857

Send, U., Davis, R. E., Fischer, J., Imawaki, S., Kessler, W., Meinen, C., et al. (2010). "A global boundary current circulation observing network," in Proceedings of OceanObs'09: Sustained Ocean Observations and Information for Society, Vol. 2, eds J. Hall, D. E. Harrison, and D. Stammer (Venice: ESA Publication WPP-306), doi: 10.5270/OceanObs09.cwp.78

Send, U., Regier, L., and Jones, B. (2013). Use of underwater gliders for acoustic data retrieval from subsurface oceanographic instrumentation and bidirectional communication in the deep ocean. J. Atmos. Ocean Technol. 30, 984-998. doi: 10.1175/JTECH-D-11-00169.1

Shannon, L. V., and Nelson, G. (1996). "The Benguela: large-scale features and processes and system variability," in The South Atlantic: Present and Past Circulation, eds G. Wefer, W. H. Berger, G. Seidler, and D. J. Webb (Berlin: Springer-Verlag), 163-210. doi: 10.1007/978-3-642-80353-6_9

Shinoda, A., Aoyama, J., Miller, M. J., Otake, T., Mochioka, N., Watanabe, S., et al. (2011). Evaluation of the larval distribution and migration of the Japanese eel in the western North Pacific. Rev. Fish. Biol. Fisher. 21, 591-611. doi: 10.1007/ s11160-010-9195-1

Siedlecki, S. A., Kaplan, I. C., Hermann, A. J., Nguyen, T. T., Bond, N. A., Newton, J. A., et al. (2016). Experiments with seasonal forecasts of ocean conditions for the Northern region of the California Current upwelling system. Sci. Rep. 6:27203. doi: 10.1038/srep27203

Silva, N., Rojas, N., and Fedele, A. (2009). Water masses in the Humboldt Current System: properties, distribution, and the nitrate deficit as a chemical water mass 
tracer for Equatorial Subsurface Water off Chile. Deep Sea Res. Part II 56, 1004-1020. doi: 10.1016/j.dsr2.2008.12.013

Siqueira, L., and Kirtman, B. P. (2016). Atlantic near-term climate variability and the role of a resolved Gulf Stream. Geophys. Res. Lett. 43, 3964-3972. doi: 10.1002/2016GL068694

Slangen, A. B. A., Carson, M., Katsman, C. A., van de Wal, R. S. W., Köhl, A., Vermeersen, L. L. A., et al. (2014). Projecting twenty-first century regional sea-level changes. Clim. Chang. 124, 317-332. doi: 10.1007/s10584-014-1080-9

Sloyan, B. M., and O'Kane, T. J. (2015). Drivers of decadal variability in the Tasman Sea. J. Geophys. Res. 120, 3193-3210. doi: 10.1002/2014JC010550

Sloyan, B. M., Ridgway, K., and Cowley, R. (2016). The East Australian Current and property transport at $27^{\circ} \mathrm{S}$ from 2012-2013. J. Phys. Oceanogr. 46, 993-1008. doi: 10.1175/JPO-D-15-0052.1

Smith, L. M., Barth, J. A., Kelley, D. S., Plueddemann, A., Rodero, I., Ulses, G. A., et al. (2018). The Ocean Observatories Initiative. Oceanography 31, 16-35. doi: 10.5670/oceanog.2018.105

Smith, N., Kessler, W. S., Cravatte, S. E., Sprintall, J., Wijffels, S. E., Cronin, M. F., et al. (2019). Tropical Pacific Observing System. Front. Mar. Sci. 6:31. doi: $10.3389 /$ fmars.2019.00031

Soh, H. S., and Kim, S. Y. (2018). Diagnostic characteristics of submesoscale coastal surface currents. J. Geophys. Res. 123, 1838-1859. doi: 10.1002/2017JC013428

Song, H., Edwards, C. A., Moore, A. M., and Fiechter, J. (2012). Incremental fourdimensional variational data assimilation of positive-definite oceanic variables using a logarithm transformation. Ocean Model. 54-55, 1-17. doi: 10.1016/j. ocemod.2012.06.001

Spadone, A., and Provost, C. (2009). Variations in the Malvinas Current volume transport since October 1992. J. Geophys. Res. 114:C02002. doi: 10.1029/ 2008JC004882

St. Laurent, L., and Merrifield, S. (2017). Measurements of near-surface turbulence and mixing from autonomous ocean gliders. Oceanography 30, 116-125. doi: 10.5670/oceanog.2017.231

Steinfeldt, R., Sültenfuß, J., Dengler, M., Fischer, T., and Rhein, M. (2015). Coastal upwelling off Peru and Mauritania inferred from helium isotope disequilibrium. Biogeosciences 12, 7519-7533. doi: 10.5194/bg-12-7519-2015

Strub, P. T., James, C., Combes, V., Matano, R., Piola, A., Palma, E., et al. (2015). Altimeter-derived seasonal circulation on the SW Atlantic Shelf: $27^{\circ}-43^{\circ} \mathrm{S}$. J. Geophys. Res. Oceans 120, 3391-3418. doi: 10.1002/2015JC010769

Stuart-Smith, R. D., Brown, C. J., Ceccarelli, D. M., and Edgar, G. J. (2018). Ecosystem restructuring along the Great Barrier Reef following mass coral bleaching. Nature 560, 92-96. doi: 10.1038/s41586-018-0359-9

Subramanian, A., Balmaseda, M. A., Chattopadhyay, R., Centurioni, L. R., Cornuelle, B. D., DeMott, C., et al. (2019). Ocean observations to improve our understanding, modeling, and forecasting of subseasonal-to-seasonal variability. Front. Mar. Sci. 6:427. doi: 10.3389/fmars.2019.00427

Sugimoto, S., and Hanawa, K. (2014). Influence of Kuroshio path variation south of Japan on formation of subtropical mode water. J. Phys. Oceanogr. 44, 1065-1077. doi: 10.1175/jpo-d-13-0114.1

Sun, X., Vizy, E. K., and Cook, K. H. (2018). Land-atmosphere-ocean interactions in the southeastern Atlantic: interannual variability. Clim. Dyn. 52:539. doi: 10.1007/s00382-018-4155-x

Suthers, I. M., Young, J. W., Baird, M. E., Roughan, M., Everett, J. E., Brassington, G. B., et al. (2011). The strengthening East Australian Current, its eddies and biological effects-an introduction and overview. Deep Sea Res. 58, 538-546. doi: 10.1016/j.dsr2.2010.09.029

Sutton, A. J., Sabine, C. L., Feely, R. A., Cai, W.-J., Cronin, M. F., McPhaden, M. J., et al. (2016). Using present-day observations to detect when anthropogenic change forces surface ocean carbonate chemistry outside preindustrial bounds. Biogeosciences 13, 5065-5083. doi: 10.5194/bg-2016-104

Sutton, A. J., Sabine, C. L., Maenner-Jones, S., Lawrence-Slavas, N., Meinig, C., Feely, R. A., et al. (2014). A high-frequency atmospheric and seawater $\mathrm{pCO}_{2}$ data set from 14 open-ocean sites using a moored autonomous system. Earth Syst. Sci. Data 6, 353-366. doi: 10.5194/essd-6-353-2014

Sutton, A. J., Wanninkhof, R., Sabine, C. L., Feely, R. A., Cronin, M. F., and Weller, R. A. (2017). Variability and trends in surface seawater $\mathrm{pCO}_{2}$ and $\mathrm{CO}_{2}$ flux in the Pacific Ocean. Geophys. Res. Lett. 44, 5627-5636. doi: 10.1002/ 2017GL073814

Takahashi, T., Sutherland, S. C., Wanninkhof, R., Sweeney, C., Feely, R. A., Chipman, D. W., et al. (2009). Climatological mean and decadal change in surface ocean $\mathrm{pCO}_{2}$, and net sea-air $\mathrm{CO}_{2}$ flux over the global oceans. Deep Sea Res. II 56, 554-577. doi: 10.1016/j.dsr2.2008.12.009

Talley, L. D., Feely, R. A., Sloyan, B. M., Wanninkhof, R., Baringer, M. O., Bulliser, J. L., et al. (2016). Changes in ocean heat, carbon content, and ventilation: a review of the first decade of GO-SHIP global repeat hydrography. Ann. Rev. Mar. Sci. 8, 185-215. doi: 10.1146/annurev-marine-052915100829

Tchipalanga, P., Dengler, M., Brandt, P., Kopte, R., Macuéria, M., Coelho, P., et al. (2018). Eastern boundary circulation and hydrography off Angola-building Angolan oceanographic capacities. Bull. Am. Meteor. Soc. 99, 1589-1605. doi: 10.1175/BAMS-D-17-0197.1

Testor, P., DeYoung, B., Rudnick, D. L., Glenn, S., Hayes, D., Lee, C., et al. (2019). OceanGliders: a component of the integrated GOOS. Front. Mar. Sci. 6:422. doi: $10.3389 /$ fmars.2019.00422

Thompson, J. D., and Schmitz, W. J. Jr. (1989). A limited-area model of the Gulf Stream: design, initial experiments, and model-data intercomparison. J. Phys. Oceanogr. 19, 791-814. doi: 10.1175/1520-0485(1989)019<0791:alamot> 2.0.co; 2

Thomsen, S., Karstensen, J., Kiko, R., Krahmann, G., Dengler, M., and Engel, A. (2019). Remote and local drivers of oxygen and nitrate variability in the shallow oxygen minimum zone off Mauritania in June 2014. Biogeosciences 16, 979-998. doi: 10.5194/bg-16-979-2019

Todd, R. E. (2017). High-frequency internal waves and thick bottom mixed layers observed by gliders in the Gulf Stream. Geophys. Res. Lett. 44, 6316-6325. doi: 10.1002/2017GL072580

Todd, R. E., and Locke-Wynn, L. (2017). Underwater glider observations and the representation of western boundary currents in numerical models. Oceanography 30, 88-89. doi: 10.5670/oceanog.2017.225

Todd, R. E., and Owens, B. (2016). Data from: Gliders in the Gulf Stream. La Jolla, CA: Instrument Development Group, Scripps Institution of Oceanography, doi: 10.21238/s8SPRAY2675

Todd, R. E., Asher, T. G., Heiderich, J., Bane, J. M., and Luettich, R. A. (2018a). Transient response of the Gulf Stream to multiple hurricanes in 2017. Geophys. Res. Lett. 45, 10509-10519. doi: 10.1029/2018GL079180

Todd, R. E., Rudnick, D. L., Centurioni, L. R., Jayne, S. R., and Lee, C. M. (2018b). "Boundary current observations with ALPS," in ALPS II-Autonomous and Lagrangian Platforms and Sensors. A Report of the ALPS II Workshop, eds D. Rudnick, D. Costa, C. Lee, and M.-L. Timmermans (Washington, DC: National Oceanographic Partnership Program).

Todd, R. E., Gawarkiewicz, G. G., and Owens, W. B. (2013). Horizontal scales of variability over the Middle Atlantic Bight shelf break and continental rise from finescale observations. J. Phys. Oceanogr. 43, 222-230. doi: 10.1175/JPO-D-12099.1

Todd, R. E., Owens, W. B., and Rudnick, D. L. (2016). Potential vorticity structure in the North Atlantic western boundary current from underwater glider observations. J. Phys. Oceanogr. 46, 327-348. doi: 10.1175/JPO-D-150112.1

Todd, R. E., Rudnick, D. L., Davis, R. E., and Ohman, M. D. (2011a). Underwater gliders reveal rapid arrival of El Niño effects off California's coast. Geophys. Res. Lett. 38:L03609. doi: 10.1029/2010GL046376

Todd, R. E., Rudnick, D. L., Mazloff, M. R., Davis, R. E., and Cornuelle, B. D. (2011b). Poleward flows in the southern California Current System: Glider observations and numerical simulation. J. Geophys. Res. 116:C02026. doi: 10. 1029/2010JC006536

Todd, R. E., Rudnick, D. L., Mazloff, M. R., Cornuelle, B. D., and Davis, R. E. (2012). Thermohaline structure in the California Current System: Observations and modeling of spice variance. J. Geophys. Res. 117:C02008. doi: 10.1029/ 2011JC007589

Todd, R. E., Rudnick, D. L., Sherman, J. T., Owens, W. B., and George, L. (2017). Absolute velocity estimates from autonomous underwater gliders equipped with Doppler current profilers. J. Atmos. Ocean. Technol. 34, 309-333. doi: 10.1175/JTECH-D-16-0156.1

Toole, J. M., Andres, M., Le Bras, I. A., Joyce, T. M., and McCartney, M. S. (2017). Moored observations of the deep western boundary current in the NW Atlantic: 2004-2014. Oceans 122, 7488-7505. doi: 10.1002/2017JC012984

Trowbridge, J., Weller, R., Kelley, D., Dever, E., Plueddemann, A., Barth, J. A., et al. (2019). The Ocean Observatories Initiative. Front. Mar. Sci. 6:74. doi: $10.3389 /$ fmars.2019.00074 
Valdivieso, M., Haines, K., Balmaseda, M., Chang, Y.-S., Drevillon, M., Ferry, N., et al. (2017). An assessment of air-sea heat fluxes from ocean and coupled reanalyses. Clim. Dyn. 49, 983-1008. doi: 10.1007/s00382-015-2843-3

Valla, D., and Piola, A. R. (2015). Evidence of upwelling events at the northern Patagonian shelf break. J. Geophys. Res. Oceans 120, 7635-7656. doi: 10.1002/ $2015 \mathrm{jc} 011002$

Valla, D., Piola, A. R., Meinen, C. S., and Campos, E. (2018). Strong mixing and recirculation in the northwestern Argentine Basin. J. Geophys. Res. Oceans 123, 4624-4648. doi: 10.1029/2018JC013907

Van der Lingen, C. D., Fréon, P., Hutchings, L., Roy, C., Bailey, G. W., Bartholomae, C., et al. (2006). "Forecasting shelf processes of relevance to living marine resources in the BCLME," in Benguela: Predicting a Large Marine Ecosystem, Large Mar. Ecosyst. Ser, Vol. 14, ed. V. Shannon (Amsterdam: Elsevier), 309347. doi: 10.1016/s1570-0461(06)80019-4

van Sebille, E., Baringer, M. O., Johns, W. E., Beal, L. M., de Jong, M. F., van Aken, H. M., et al. (2011). Propagation pathways of classical Labrador Sea Water from its source region to $26^{\circ}$ N. J. Geophys. Res. 116:C12027. doi: 10.1029/ 2011JC007171

van Sebille, E., Beal, L. M., and Biastoch, A. (2010). Sea surface slope as a proxy for Agulhas Current strength. Geophys. Res. Lett 37:L09610.

van Sebille, E., Wilcox, C., Lebreton, L., Maximenko, N., Hardesty, B. D., Van Franekar, J. A., et al. (2015). A global inventory of small floating plastic debris. Environ. Res. Lett 10:124006. doi: 10.1088/1748-9326/10/12/124006

Van Uffelen, L. J., Roth, E. H., Howe, B. M., Oleson, E. M., and Barkley, Y. (2017). A Seaglider-integrated digital monitor for bioacoustic sensing. IEEE J. Ocean. Eng. 42, 800-807. doi: 10.1109/JOE.2016.2637199

Vélez-Belchí, P., Centurioni, L. R., Lee, D.-K., Jan, S., and Niiler, P. P. (2013). Eddy induced Kuroshio intrusions onto the continental shelf of the East China Sea. J. Mar. Res. 71, 83-107. doi: 10.1357/002224013807343470

Vivier, F., and Provost, C. (1999). Direct velocity measurements in the malvinas current. J. Geophys. Res. 104, 21083-21103. doi: 10.1029/1999JC900163

Volkov, D. L., Baringer, M., Smeed, D., Johns, W., and Landerer, F. (2019). Teleconnection between the Atlantic meridional overturning circulation and sea level in the Mediterranean Sea. J. Clim. 32, 935-955. doi: 10.1175/JCLI-D18-0474.1

Wada, A., Cronin, M. F., Sutton, A. J., Kawai, Y., and Ishii, M. (2013). Numerical simulations of oceanic $\mathrm{pCO}_{2}$ variations and interactions between typhoon Choi-wan (0914) and the ocean. J. Geophys. Res. Oceans 118, 2667-2684. doi: 10.1002 /jgrc. 20203

Wagawa, T., Tamate, T., Kuroda, H., Ito, S., Kakehi, S., Yamanome, T., et al. (2016). Relationship between coastal water properties and adult return of chum salmon (Oncorhynchus keta) along the Sanriku coast, Japan. Fish. Oceangr. 25, 598-609. doi: 10.1111/fog. 12175

Wakita, M., Watanabe, S., Murata, A., Tsurushima, N., and Honda, M. (2010). Decadal change of dissolved inorganic carbon in the subarctic western North Pacific Ocean. Tellus B 62, 608-620. doi: 10.1111/j.1600-0889.2010.00476.x

Wang, D., Flagg, C. N., Donohue, K., and Rossby, H. T. (2010). Wavenumber spectrum in the Gulf Stream from shipboard ADCP observations and comparison with altimetry measurements. J. Phys. Oceanogr. 40, 840-844. doi: 10.1175/2009JPO4330.1

Wang, F., Zhang, L., Hu, D., Wang, Q., Zhai, F., and Hu, S. (2017). The vertical structure and variability of the western boundary currents east of the Philippines from direct observations. J. Oceanogr. 73, 743-758. doi: 10.1007/ s10872-017-0429-x

Weeks, S. J., Barlow, R., Roy, C., and Shillington, F. A. (2006). Remotely sensed variability of temperature and chlorophyll in the southern Benguela: upwelling frequency and phytoplankton response. Afr. J. Mar. Sci. 28, 493-509. doi: 10. 2989/18142320609504201

Weller, R. A., Bigorre, S. P., Lord, J., Ware, J. D., and Edson, J. B. (2012). A surface mooring for air-sea interaction research in the Gulf Stream. Part I: mooring design and instrumentation. J. Atmos. Ocean. Technol. 29, 1363-1376. doi: 10.1175/JTECH-D-12-00060.1

Wijffels, S. E., Meyers, G., and Godfrey, J. S. (2008). A 20-yr average of the Indonesian Throughflow: regional currents and the interbasin exchange. J. Phys. Oceanogr. 38, 1965-1978. doi: 10.1175/2008JPO3987.1

Wilkinson, M. D., Dumontier, M., Aalbersberg, I. J., Appleton, G., Axton, M., Baak, A., et al. (2016). The FAIR guiding principles for scientific data management and stewardship. Sci. Data 3:160018. doi: 10.1038/sdata.2016.18
Williams, R. G., McDonagh, E. L., Roussenov, V. M., Torres-Valdes, S., King, B., Sanders, R., et al. (2011). Nutrient streams in the North Atlantic: advective pathways of inorganic and organic nutrients. Glob. Biogeochem. Cycles 25:GB4008. doi: 10.1029/2010GB003853

Williams, R. G., Roussenov, V., and Follows, M. J. (2006). Nutrient streams and their induction into the mixed layer. Glob. Biogeochem. Cycles 20:GB1016. doi: 10.1029/2005gb002586

Woo, L. M., and Pattiaratchi, C. B. (2008). Hydrography and water masses off the western Australian coast. Deep Sea Res. I 55, 1090-1104. doi: 10.1016/j.dsr.2008. 05.005

Wu, C.-R., Chang, Y.-L., Oey, L.-Y., Chang, C.-W. J., and Hsin, Y.-C. (2008). Airsea interaction between tropical cyclone Nari and Kuroshio. Geophys. Res. Lett. 35:L12605. doi: 10.1029/2008GL033942

Wu, L., Cai, W., Zhang, L., Nakamura, H., Timmermann, A., Joyce, T., et al. (2012). Enhanced warming over the global subtropical western boundary currents. Nat. Clim. Chang. 2, 161-166. doi: 10.1038/nclimate1353

Wyatt, L. R., Mantovanelli, A., Heron, M. L., Roughan, M., and Steinberg, C. R. (2018). Assessment of surface currents measured with high-frequency phasedarray radars in two regions of complex circulation IEEE. J. Ocean. Eng. 43, 484-505. doi: 10.1109/JOE.2017.2704165

Yamamoto, A., Palter, J. B., Dufour, C. O., Griffies, S. M., Bianchi, D., Claret, M., et al. (2018). Roles of the ocean mesoscale in the horizontal supply of mass, heat, carbon and nutrients to the Northern Hemisphere subtropical gyres. J. Geophys. Res. 123, 7016-7036. doi: 10.1029/2018JC013969

Yang, H., Lohmann, G., Wei, W., Dima, M., Ionita, M., and Liu, J. (2016). Intensification and poleward shift of subtropical western boundary currents in a warming climate. Oceans 121, 4928-4945. doi: 10.1002/2015JC0 11513

Yang, Y. J., Jan, S., Chang, M.-H., Wang, J., Mensah, V., Kuo, T.-H., et al. (2015). Mean structure and fluctuations of the Kuroshio east of Taiwan from in situ and remote observations. Oceanography 28, 74-83. doi: 10.5670/oceanog. 2015.83

Yasuda, I. (2003). Hydrographic structure and variability in the KuroshioOyashio transition area. J. Oceanogr. 59, 389-402. doi: 10.1023/A:10255803 13836

Yasunaka, S., Nojiri, Y., Nakaoka, S., Ono, T., Mukai, H., and Usui, N. (2013). Monthly maps of sea surface dissolved inorganic carbon in the North Pacific: basin-wide distribution and seasonal variation. J. Geophys. Res. Oceans 118, 3843-3850. doi: 10.1002/jgrc.20279

Yasunaka, S., Nojiri, Y., Nakaoka, S.-I., Ono, T., Whitney, F. A., and Telszewski, M. (2014). Mapping of sea surface nutrients in the North Pacific: basin-wide distribution and seasonal to interannual variability. J. Geophys. Res. Oceans 119, 7756-7771. doi: 10.1002/2014jc010318

Zaba, K. D., and Rudnick, D. L. (2016). The 2014-2015 warming anomaly in the Southern California Current System observed by underwater gliders. Geophys. Res. Lett. 43, 1241-1248. doi: 10.1002/2015GL067550

Zantopp, R., Fischer, J., Visbeck, M., and Karstensen, J. (2017). From interannual to decadal: 17 years of boundary current transports at the exit of the Labrador Sea. J. Geophys. Res. Oceans 122, 1724-1748. doi: 10.1002/2016JC01 2271

Zhang, D., Cronin, M. F., Lin, X., Inoue, R., Fassbender, A. J., Bishop, S. P., et al. (2017). Observing air-sea interaction in western boundary currents and their extension regions: considerations for OceanObs' 19. CLIVAR Variations 15, 23-30. doi: 10.5065/D6SJ1JB2

Zhang, D., Msadek, R., McPhaden, M. J., and Delworth, T. (2011). Multidecadal variability of the North Brazil Current and its connection to the atlantic meridional overturning circulation. J. Geophys. Res. 116:C04012. doi: 10.1029/ 2010JC006812

Zhang, J., Gilbert, D., Gooday, A. J., Levin, L., Naqvi, S. W. A., Middelburg, J. J., et al. (2010). Natural and human-induced hypoxia and consequences for coastal areas: synthesis and future development. Biogeosciences 7, 1443-1467. doi: 10.5194/bg-7-1443-2010

Zhang, L., Hu, D., Hu, S., Wang, F., Wang, F., and Yuan, D. (2014). Mindanao current/undercurrent measured by a subsurface mooring. J. Geophys. Res. 119, 3617-3628. doi: 10.1002/2013JC009693

Zhang, S., Curchitser, E. N., Kang, D., Stock, C. A., and Dussin, R. (2018). Impacts of mesoscale eddies on the vertical nitrate flux in the Gulf stream region. J. Geophys. Res. 123, 497-513. doi: 10.1002/2017JC013402 
Zhang, W. G., and Gawarkiewicz, G. G. (2015). Dynamics of the direct intrusion of gulf stream ring water onto the Mid-Atlantic Bight shelf. Geophys. Res. Lett. 42, 7687-7695. doi: 10.1002/2015GL065530

Zhang, W. G., and Partida, J. (2018). Frontal subduction of the Mid-Atlantic Bight shelf water at the onshore edge of a warm-core ring. J. Geophys. Res. 123, 7795-7818. doi: 10.1029/2018JC013794

Zhang, Z., Zhao, W., Tian, J., Yang, Q., and Qu, T. (2015). Spatial structure and temporal variability of the zonal flow in the Luzon Strait. J. Geophys. Res. 120, 759-776. doi: 10.1002/2014JC010308

Zhou, C., Zhao, W., Tian, J., Yang, Q., and Qu, T. (2014). Variability of the deepwater overflow in the luzon strait. J. Phys. Oceanogr. 44, 2972-2986. doi: 10. 1175/JPO-D-14-0113.1

Zilberman, N. V., Roemmich, D. H., Gille, S. T., and Gilson, J. (2018). Estimating the velocity and transport of western boundary current systems: a case study of the East Australian Current near Brisbane. J. Atmos. Ocean. Technol. 35, 1313-1329. doi: 10.1175/JTECH-D-170153.1

Zilberman, N. V., Roemmich, D., and Gille, S. (2013). The mean and the time variability of the shallow meridional overturning circulation in the tropical South Pacific Ocean. J. Clim. 26, 4069-4087. doi: 10.1175/JCLI-D-1200120.1

Zilberman, N. V., Roemmich, D., and Gille, S. (2014). Meridional volume transport in the South Pacific: mean and SAM-related variability. J. Geophys. Res. Oceans. 119, 2658-2678. doi: 10.1002/2013JC009688
Zuidema, P., Chang, P., Medeiros, B., Kirtman, B. P., Mechoso, R., Schneider, E. K., et al. (2016). Challenges and prospects for reducing coupled climate model SST biases in the eastern tropical Atlantic and Pacific Oceans: the U.S. CLIVAR eastern tropical oceans synthesis working group. Bull. Am. Meteor. Soc. 97, 2305-2328. doi: 10.1175/BAMS-D-15-00274.1

Conflict of Interest Statement: The authors declare that the research was conducted in the absence of any commercial or financial relationships that could be construed as a potential conflict of interest.

Copyright (C) 2019 Todd, Chavez, Clayton, Cravatte, Goes, Graco, Lin, Sprintall, Zilberman, Archer, Arístegui, Balmaseda, Bane, Baringer, Barth, Beal, Brandt, Calil, Campos, Centurioni, Chidichimo, Cirano, Cronin, Curchitser, Davis, Dengler, deYoung, Dong, Escribano, Fassbender, Fawcett, Feng, Goni, Gray, Gutiérrez, Hebert, Hummels, Ito, Krug, Lacan, Laurindo, Lazar, Lee, Lengaigne, Levine, Middleton, Montes, Muglia, Nagai, Palevsky, Palter, Phillips, Piola, Plueddemann, Qiu, Rodrigues, Roughan, Rudnick, Rykaczewski, Saraceno, Seim, Sen Gupta, Shannon, Sloyan, Sutton, Thompson, van der Plas, Volkov, Wilkin, Zhang and Zhang. This is an open-access article distributed under the terms of the Creative Commons Attribution License (CC BY). The use, distribution or reproduction in other forums is permitted, provided the original author(s) and the copyright owner(s) are credited and that the original publication in this journal is cited, in accordance with accepted academic practice. No use, distribution or reproduction is permitted which does not comply with these terms. 